MATHEUS LEVI TAJRA FEITOSA

Terapia Celular com Células-Tronco em Coelhos com Lesão Medular I nduzida e em Cães com Lesão Medular Crônica Espontânea

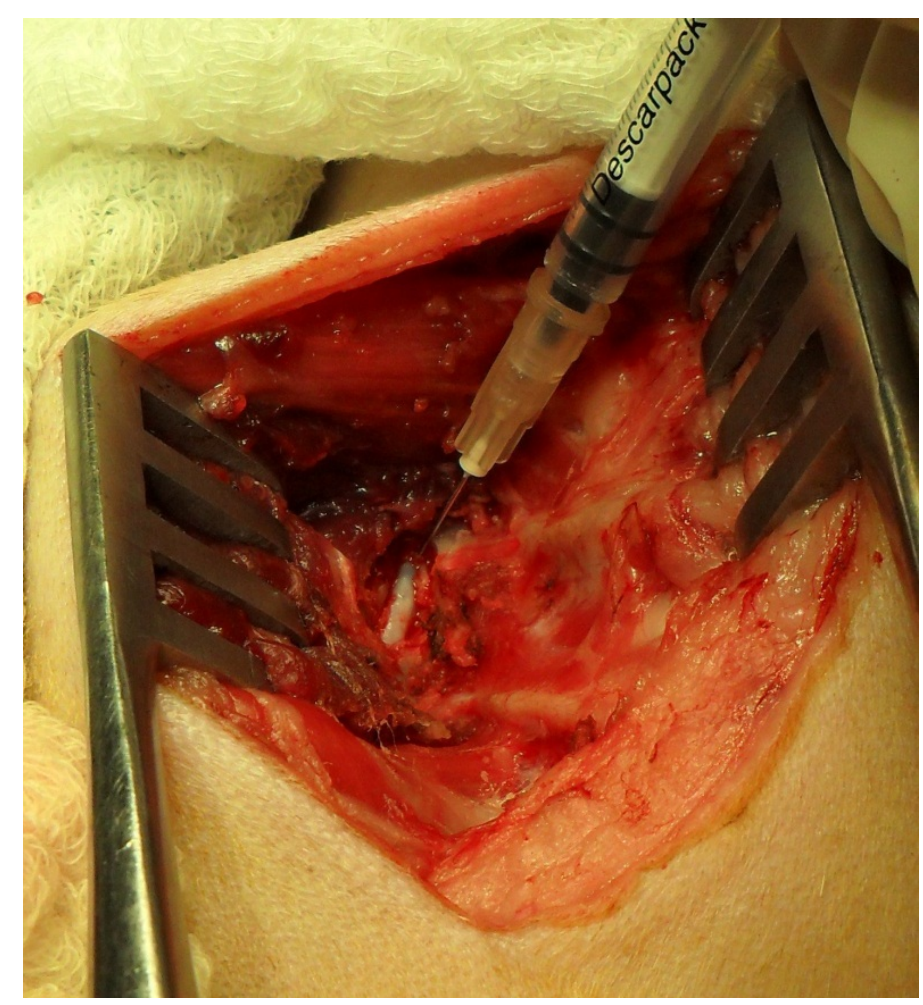

São Paulo 


\section{Terapia Celular com Células-Tronco em Coelhos com Lesão Medular I nduzida e em Cães com Lesão Medular Crônica Espontânea}

Tese apresentada ao Programa de PósGraduação em Anatomia dos Animais Domésticos e Silvestres da Faculdade de Medicina Veterinária e Zootecnia da Universidade de São Paulo para Obtenção do Título de Doutor em Ciências

Departamento:

Cirurgia

Área de Concentração:

Anatomia dos Animais Domésticos e Silvestres

Orientador:

Prof. Dr. Carlos Eduardo Ambrósio 
Autorizo a reprodução parcial ou total desta obra, para fins acadêmicos, desde que citada a fonte.

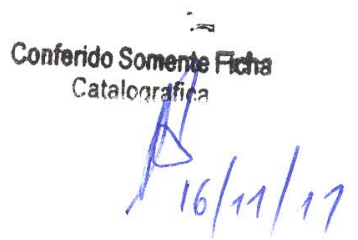

\section{DADOS INTERNACIONAIS DE CATALOGAÇÃO-NA-PUBLICAÇÃO}

(Biblioteca Virginie Buff D’Ápice da Faculdade de Medicina Veterinária e Zootecnia da Universidade de São Paulo)

Feitosa, Matheus Levi Tajra

FMVZ

Terapia celular com células-tronco em coelhos com lesão medular induzida e em cães com lesão medular crônica espontânea / Matheus Levi Tajra Feitosa.-- 2011.

$$
131 \mathrm{f} \text { : : il. }
$$

Tese (Doutorado) - Universidade de São Paulo. Faculdade de Medicina Veterinária e Zootecnia. Departamento de Cirurgia, São Paulo, 2011.

Programa de Pós-Graduação: Anatomia dos Animais Domésticos e Silvestres.

Área de concentração: Anatomia dos Animais Domésticos e Silvestres.

Orientador: Prof. Dr. Carlos Eduardo Ambrósio

1. Coelhos. 2. Cães. 3. Célula-Tronco. 4. Lesão medular. I. Título. 


\section{ERRATA}

FEITOSA, M. L. T. Terapia celular com células-tronco em coelhos com lesão medular induzida e em cães com lesão medular crônica espontânea. 2011. 131 f. Tese (Doutorado) - Faculdade de Medicina Veterinária e Zootecnia, Universidade de São Paulo, São Paulo, 2011.
Página
Parágrafo
Onde se lê
Leia-se
Resumo
$118 \mathrm{f}$.
$131 \mathrm{f}$.
Abstract
4 으
$118 \mathrm{f}$.
$131 \mathrm{f}$. 


\section{FACUIDADE DE MEDICINA VETERINÁRIA E ZOOTECNIA}

\section{Comissão de Ética no uso de animais}

\section{CERTIFICADO}

Certificamos que o Projeto intitulado "Terapia celular com células tronco em coelhos com lesão medular induzida em cães com lesão medular crônica espontânea", protocolado sob o $n^{\circ}$ 2081/2010, utilizando 5 (cinco) cães e 20 (vinte) coelhos, sob a responsabilidade do Prof. Dr. Carlos Eduardo Ambrósio, está de acordo com os princípios éticos de experimentação animal da "Comissão de Ética no uso de animais" da Faculdade de Medicina Veterinária e Zootecnia da Universidade de São Paulo e foi aprovado em reunião de 16/02/2011.

São Paulo, 4 de novembro de 2011

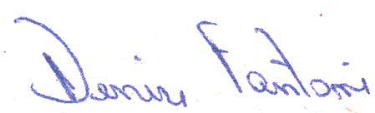

Profa. Dra. Denise Tabacchi Fantoni Presidente 


\section{FOLHA DE AVALI AÇÃO}

Nome: FEITOSA, Matheus Levi Tajra

Título: Terapia celular com células-tronco em coelhos com lesão medular induzida e em cães com lesão medular crônica

Tese apresentada à Faculdade de Medicina Veterinária da Universidade de São Paulo para Fins de Qualificação de Doutorado no Programa de Pós-Graduação em Anatomia dos Animais Domésticos e Silvestres.

Data:

\section{Banca Examinadora}

Prof.Dr.

Instituição

Prof.Dr.

Instituição

Prof.Dr.

Instituição

Prof.Dr.

Instituição

Prof.Dr.

Instituição 


\section{DEDICATÓRI A}

Dedico à minha esposa Viviane Letícia Martins, meu porto seguro, minha única família em São Paulo, a razão de ter chegado até aqui.

Eu te amo.

Dedico esta tese também a minha família, essa conquista também é de vocês. A minha mãe Silvia Maria Nogueira Tajra, meu pai Airtom Gondin

Feitosa, e aos meus irmãos, Airton Gondim Feitosa, Airton José Tajra Feitosa, Eduardo Arthur Tajra Feitosa, Lídia Tajra Feitosa, a minha avó Maria do Rosário Nogueira Tajra e a José dos Santos Carvalho. 


\section{AGRADECIMENTOS ESPECIAIS}

Ao orientador de mestrado e doutorado, Carlos Eduardo Ambrósio. Foram anos de convivência e de aprendizado que espero poder levar para toda minha carreira acadêmica, e a certeza de uma amizade e parceria por muitos outros anos;

Ao amigo de todas as horas, a pessoa que na falta dos rins desenvolveu um coração imenso, João Carlos Morini Júnior;

A Karla Patrícia Cardoso Araújo minha "companheira de escritório";

Ao técnico de laboratório Ronaldo Agostinho;

Aos inesquecíveis Marcelo Machado, Marcelo Mendes, Renato Gerger, Simone Pereira, Juliana Passos, Carlos Magenta, grandes amigos;

Tenho certeza que deixo aqui muitas amizades duradouras; 


\section{AGRADECIMENTOS}

Agradeço aos tantos amigos de pós-graduação, e perdoem os que aqui não forem lembrados de imediato;

Ao amigo Carlos Alberto Palmeira Sarmento pela parceria no projeto e amizade;

Aos colegas de pós-graduação da FZEA Fabiana Bressan, Rodrigo Barreto,

e Lilian de Jesus Oliveira pelo pronto socorro na realização das imunohistoquímicas e transdução viral das células-tronco do epitélio olfatório de coelhos;

À aluna de graduação da FZEA, Ana Ercolin, pelo isolamento e caracterização das células-tronco do epitélio olfatório de coelhos;

Ás colegas de pós-graduação da FMVZ Isabela Fernandes, Fabiele Russo e Graciela Pignatari, pela ajuda na manutenção das células-tronco da polpa dentária humanas;

Aos Professores Maria Angélica Miglino, Patrícia Braga pela co-orientação e fornecimento das células- tronco da polpa dentária respectivamente;

Ao amigo mais recente, Renato Zonzini Bocabello, pelo auxílio nos procedimentos cirúrgicos realizados nesta tese;

Agradeço a Célio dos Santos, Juliana Guimarães, Stella Sakata, Robson Giglio, médicos veterinários que ajudaram no desenvolvimento deste experimento; 
Agradeço também, aos parceiros em outros projetos e atividades, Márcio Nogueira Rodrigues, Marcos Vinícius e Juliana Casals;

Aos amigos Rafael Cardoso Carvalho, Thaís Borges Lessa;

Agradecimentos à "Família Ortolani", Frederico, Leonardo Frasson, Enoch, Carol, Humberto Hammad, Raimundo Alves Barreto, pelos tantos momentos de descontração e trabalho regrados a muitas risadas; Agradeço a Flávio Ribeiro Alves, Carlos Eduardo Cruz Pinto, André Moreni Lopes, que durante muito tempo dividiram um lar comigo;

Agradeço ao Hospital Veterinário Cães e Gatos de Osaco, importante parceiro para realização desta tese;

Por fim agradeço as instituições de fomento, CAPES, CNPq e FAPESP, pelo auxílio e bolsas fornecidas para realização dos trabalhos de mestrado e doutorado. 
AGRADECIMENTOS

A Fapesp pela concessão da bolsa de doutorado referente ao projeto de pesquisa protocolado com o no 2009/51605-04, sem a qual seria impossível a conclusão desta pesquisa. 
“O seu tempo é limitado, então não o gaste vivendo a vida de um outro alguém. Não fique preso pelos dogmas, que é o mesmo que viver com os resultados da vida de outras pessoas. Não deixe que o barulho da opinião dos outros cale a sua própria voz interior. E o mais importante: tenha coragem de seguir o seu próprio coração e a sua intuição. Eles de alguma maneira já sabem o que você realmente quer se tornar. Todo o resto é secundário”.

Steve Jobs (1955-2011)

"A vida de alguém é limitada; a honra e o respeito duram para sempre." 


\section{RESUMO}

FEITOSA, M. L. T. Terapia celular com células-tronco em coelhos com lesão medular induzida e em cães com lesão medular crônica espontânea. [Stem cell therapy in rabbits with induced spinal cord injury and in dogs with spontaneous chronic spinal cord injury]. 2011. $118 \mathrm{f}$. (Doutorado em Ciências) - Faculdade de Medicina Veterinária e Zootecnia, Universidade de São Paulo, São Paulo, 2011.

A regeneração de danos às células nervosas do sistema nervoso central (SNC) é limitada devido aos fatores intrínsecos ao próprio nicho celular. A cicatriz glial, a liberação de inibidores de crescimento axonal, e a ação fagocítica dos astrócitos são fatores que limitam essa regeneração, coibindo os processos de reestruturação axonal. As lesões medulares causam um grande impacto na vida de seus portadores e de seus familiares. $O$ uso das células tronco surgiu como uma alternativa viável ao tratamento das lesões medulares em humanos e animais. No entanto, apesar das tentativas terapêuticas em animais apresentarem resultados animadores, os ensaios clínicos realizados em humanos carecem de estudos mais aprofundados, e ainda não apresentaram resultados satisfatórios. O presente trabalho propôs a avaliação clínica do uso de células tronco da polpa dentária humana em cães com lesão medular crônica, e o uso das células tronco do epitélio olfatório de coelhos em coelhos com lesão medular induzida por hemissecção medular dorsal. Três cães foram submetidos à intervenção cirúrgica e avaliados através de teste comportamental e de ressonância magnética por imagem. Seis coelhos foram submetidos à técnica cirúrgica de hemissecção medular dorsal, e foram transplantados com células tronco do epitélio olfatório de coelhos e avaliados através de histologia e imunohistoquímica. As célulastronco do epitélio olfatório de coelhos foram rastreadas na medula espinhal dos animais 20 dias após a realização da terapia celular, confirmando o sucesso do transplante. A expressão da proteína fluorescente verde (GFP) através da imunohistoquímica comprovam o 
sucesso do transplante celular. O caso clínico canino um apresentou uma melhora clínica acentuada, pulando de um escore 4 para um escore de 8 em um curto espaço de tempo, mas não apresentou melhora nos exames de ressonância magnética. O caso clínico canino dois apresentou melhora clínica, embora a ressonância magnética mostrasse uma piora na situação da medula espinhal. E nosso caso clínico canino três apresentou mínima melhora clínica, sem alteração na imagem pré e pós operatória. Os dados obtidos com este estudo comprovam que a terapia celular com células tronco na lesão medular podem ser benéficas, no entanto ainda não representam uma cura para as lesões medulares crônicas.

PALAVRAS-CHAVE: Coelhos. Cães. Células-Tronco. Lesão Medular. 


\section{ABSTRACT}

FEITOSA, M. L. T. Stem cell therapy in rabbits with induced spinal cord injury and in dogs with spontaneous chronic spinal cord injury. [Terapia celular com células-tronco em coelhos com lesão medular induzida e em cães com lesão medular crônica espontânea]. 2011. 118 f. (Doutorado em Ciências) - Faculdade de Medicina Veterinária e Zootecnia, Universidade de São Paulo, São Paulo, 2011.

The regeneration of damaged nerve cells of the central nervous system (CNS) is limited due to factors intrinsic to the own cell niche. The glial scar, the release of axonal growth inhibitors, and the phagocytic action of astrocytes are factors that limit this regeneration, deterring axonal restructuring. The spinal cord injuries cause a great impact on the lives of sufferers and their families. The use of stem cells has emerged as a viable alternative to the treatment of spinal cord injuries in humans and animals. However, despite attempts therapies in animals show encouraging results, clinical trials performed in humans require further study, and have not had satisfactory results. This paper proposed the clinical use of stem cells from human dental pulp in dogs with chronic spinal cord injury, and the use of stem cells from the rabbit olfactory epithelium in rabbits with spinal cord injury induced by dorsal hemisection. Three dogs underwent surgery and evaluated by behavioral test and magnetic resonance imaging. Six rabbits underwent surgical technique for spinal cord dorsal hemisection and were transplanted with stem cells from the olfactory epithelium of rabbits and evaluated by histology and immunohistochemistry. Stem cells of the olfactory epithelium of rabbits were traced in the spinal cord of animals 20 days after the completion of cell therapy, confirming the success of transplantation. Green fluorescent protein (GFP) tracked by immunohistochemical evidence the success of cell transplantation. The canine clinical case one presented a marked clinical improvement, jumping from a score of 4 to a score of 8 in a short time, but there was no improvement in magnetic resonance imaging. The canine clinical case two 
showed clinical improvement, although the MRI showed a worsening situation in the spinal cord. And our canine clinical case 3 showed minimal clinical improvement, no change in image pre-and postoperatively. The data obtained from this study show that cell therapy with stem cells in spinal cord injury may be beneficial, but still not a cure for chronic spinal cord injuries.

KEY WORDS: Rabbits. Dogs. Stem Cells. Spinal Cord Injury. 


\section{LISTA DE FI GURAS}

Figura 1 - Fotografia da medula espinhal de coelho submetido à hemissecção dorsal seccionada em três porções: cranial a lesão (1), no foco da lesão medular (2), e caudal a lesão (3) ......... 52

Figura 2 - Fotografias de hemissecção dorsal em coelhos. A - Exposição da medula espinhal após laminectomia dorsal. B - Durotomia. C - Hemisecção dorsal com tesoura de íris. D - Exposição da medula após hemisecção dorsal. E - Sutura da dura máter com pontos simples separados de fio prolipropileno 7-0. F Injeção das células-tronco do epitélio olfatório de coelhos no foco da lesão medular

Figura 3 - Fotografias da técnica cirúrgica de hemissecção medular ventral em coelho. A - Passagem do fio de cerclagem de aço por baixo da medula espinhal. B - Passagem do fio de prolipropileno 7-0 por baixo da medula espinhal

Figura 4 - Fotografias da avaliação neurológica dos coelhos após a indução da lesão medular por hemissecção. A,B - Avaliação da sensação de dor profunda após pinçamento de dígito. C,D - Avaliação da sensação de dor superficial após pinçamento de interdígitos. E,F - Avaliação da manutenção postural

Figura 5 - Fotomicrografias de células-tronco do epitélio olfatório de coelhos. A - Células-tronco do epitélio olfatório de coelho. Células-tronco do epitélio olfatório do coelho transduzidas com o gene repórter GFP evidenciados pela exposição à luz UV. Aumento de 200x

Figura 6 - Cell sorting das células tronco do epitélio olfatório de coelhos, na esquerda uma população de células não transduzidas com o gene, e na direita uma população de células tronco do epitélio olfatório de coelhos eficientemente tranzduzidas com o gene repórter GFP.

Figura 7 - Fotografias das medulas coletadas de animais submetidos a terapia celular com células tronco do epitéio olfatório de coelhos. A - Seta vermelha aponta região de extensa reação astrocítica, evidenciada pela gliose evidente no foco da lesão criada. B - Seta vermelha apresenta região necrótica da medula espinhal de coelho

Figura 8 - Fotomicrografias em coloração de HE de porções da medula espinhal de coelho submetido à hemissecção dorsal da medula espinhal e injeção de células-tronco do epitélio olfatório de coelhos. A - Porção medular anterior à lesão causada, estrela evidencia área de vacuolização neuronal, aumento de 4x. B - Mesma região em aumento de 10x. C Região da medula espinhal onde foi realizada a hemissecção medular dorsal, cruz aponta região de desorganização celular 
e áreas de vacuolização neuronal. D - Mesma região da medula demonstrada em C com aumento de 10x. E - Mesma porção da medula espinhal demonstrada em $\mathrm{C}$ com aumento de 20X. F - Porção da medula espinhal posterior à lesão medular causada

Figura 9 - Fotomicrografias em coloração de hematoxilina e eosina em medula espinhal de coelhos submetidos à hemissecção dorsal da medula espinhal. A - Área de extensa rarefação celular da medula em sua porção dorsal. B - Infiltrado celular evidenciado pela estrela

Figura 10 - Fotomicrografias em coloração de azul de alcian da medula espinhal de coelhos submetidos à hemissecção medular dorsal. A - Sulfato de condroitina corado pelo azul de alcian. B - Dura máter corada pelo azul de alcian. C - Infiltrado inflamatório e sulfato de condroitina corados pelo azul de alcian. D - Hemissecção medular dorsal delimitada

Figura 11 - Expressão do anticorpo anti-sulfato de condroitina na lesão medular espinhal por hemissecção dorsal em coelhos. A Controle negativo sem anticorpo primário. B - Expressão de sulfato de condroitina proteoglicano na lesão medular espinhal de coelhos causada por hemissecção dorsal.

Figura 12 - Expressão do anticorpo anti-GFP em porção de medula espinhal de coelhos submetidos à hemissecção medular dorsal da medula espinhal. A - Controle negativo sem anticorpo primário. B - Ensaio positivo com anticorpo primário demonstrando a expressão do anticorpo anti GFP na porção dorsal da medula espinha

Figura 13 - Ressonância magnética da coluna vertebral toracolombar de cão da raça Ihasa apso. A - Dilatação fluida do canal central medular anterior à compressão de T12-13. B - Compressão medular ventral e a direita em T12-13 apontada pela seta vermelha. C - Extrusão discal em T12-13 e protusão discal em L1-2

Figura 14 - Fotografias do transplante de Células Tronco da Polpa Dentária Humana Imatura em cão da raça Ihasa apso. A Material extrusado do núcleo pulposo do disco intervertebral firmemente aderido a dura-máter. B - Grânulo de fibrina que se encontrava aderido a dura-máter da medula espinhal do cão. C - Aspecto da medula espinhal após retirada do grânulo da medula espinhal. D - Retirada das células-tronco da polpa dentária humana de ependorf, para posterior aplicação no foco da lesão medular. E - Aplicação das células-tronco da polpa dentária humana no foco da lesão medular. F - Aspecto final da cirurgia

Figura 15 - Ressonância magnética de cão da raça Ihasa apso após 3 meses da realização do transplante das células tronco da polpa dentária humana imatura. A - Mini hemilaminectomia 
realizada em vértebra T12. B - Dilatação do canal central da medula espinhal e algum conteúdo discal extruído ventral e a direita. C - Aumento do hipersinal medular e compressão ventral da medula espinhal. Setas vermelhas apontam o local exato das observações

Figura 16 - Ressonância Magnética da coluna toracolombar de cão da raça Daschund. A - Aumento do canal central medular e conteúdo comprimindo a medula em porção lombar em pequena quantidade. B - Extrusão discal com compressão medular severa em L4-5. C - Compressão medular severa em L4-5. D Área de aparente necrose medular espinhal em T13-L1. Setas vermelhas indicam o local exato das observações

Figura 17 - Transplante de células-tronco da polpa dentária humana imatura em cão da Daschund. A - Realização do acesso à medula espinhal com auxílio do drill pneumático. B - Retirada de material do núcleo pulposo calcificado, firmemente aderido à dura-máter da medula espinhal. C - Apresentação da medula espinhal após retirada de material calcificado, aderido a duramáter. D - Aplicação das células-tronco da polpa dentária humana imaturas no foco da lesão medular

Figura 18 - Ressonância Magnética da coluna toracolombar de cão da raça Daschund. A - Aumento do canal central medular e conteúdo comprimindo a medula na altura dos espaços intervertbrais T13L1 em pequena quantidade no assoalho do canal vertebral. B Extrusão discal com compressão medular severa em L4-5, ventral e a direita. C - Compressão medular severa em L4-5 e aumento do hipersinal epidural desde T13 até L1. D Siringohidromielia de T11 até L1. Setas vermelhas indicam o local exato das observações.

Figura 19 - Ressonância Magnética da coluna toracolombar de cão da raça Yorkshire Terrier. A - Local da intervenção cirúrgica anterior. B Atrofia medular na altura da vértebra T11

Figura 20 - Transplante de células-tronco da polpa dentária humana imatura em cão da Yorkshire. A - Cão posicionado para a realização do procedimento cirúrgico. B - Aplicação das células-tronco da polpa dentária humana no espaço intervertebral de T10-11 ....... 100 


\section{LISTA DE TABELAS}

Tabela 1 - Casos clínicos selecionados.......................................... 77

Tabela 2 - Bioquímica sérica dos animais experimentais .................... 78

Tabela 3 - Eritrograma dos animais experimentais ........................ 78

Tabela 4 - Leucograma dos animais experimentais ......................... 79 


\section{LISTA DE GRÁFI COS}

Gráfico 1 - Avaliação através do teste de Basso et al. (1995) obtidas pelos coelhos submetidos à hemissecção dorsal e ventral, por 30 dias

Gráfico 2 - Teste comportamental de Olby et al. (2001) realizado em cão da raça lhasa apso submetido à terapia celular com células tronco da polpa dentária imatura humana ....

Gráfico 3 - Gráfico do teste comportamental de Olby et al. (2001) realizado em cão da raça Teckel submetido à terapia celular com células tronco da polpa dentária humana imaturas....................................................... 97

Gráfico 4 - Teste comportamental de Olby et al. (2001) realizado em cão da raça Teckel submetido à terapia celular com células tronco da polpa dentária imatura humana 


\section{SUMÁRIO}

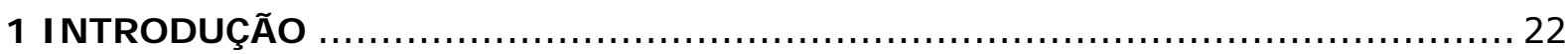

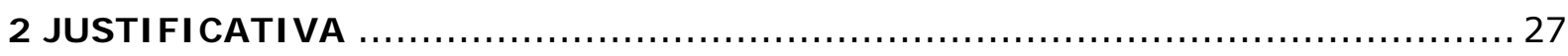

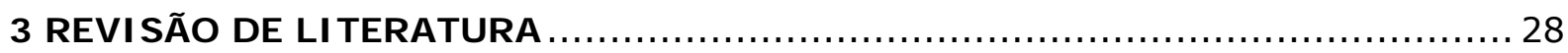

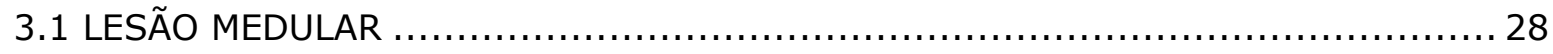

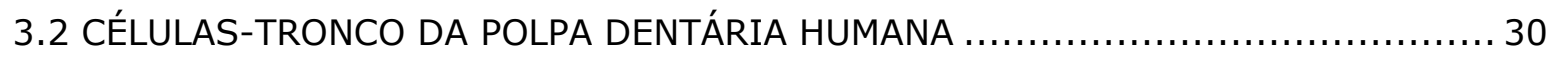

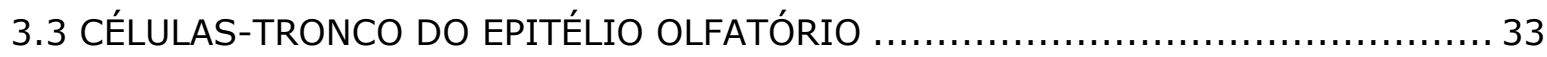

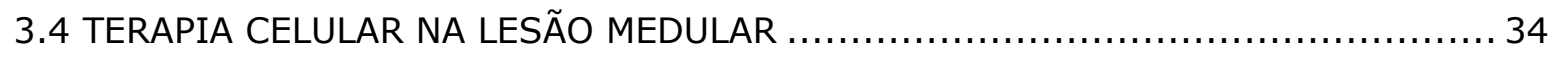

3.5 USO DE VETORES RETROVIRAIS NO RASTREAMENTO PÓS-TRANSPLANTE ........ 37

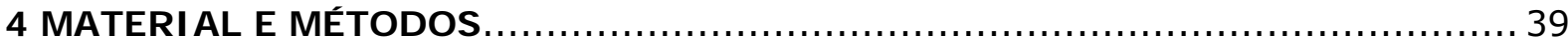

4.1 CULTIVO MANEJO E TRANSDUÇÃO DAS CÉLULAS-TRONCO UTILIZADAS ............ 39

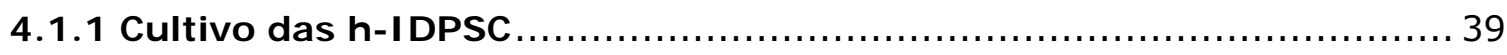

4.1.2 I solamento e Cultivo das Células Tronco do Epitélio Olfatório de

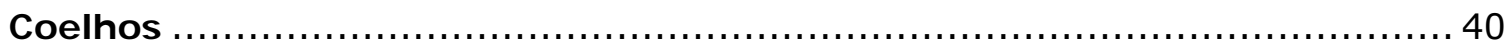

4.1.3 Produção das Células HEK 293T produtoras de lentivírus ............... 43

4.1.4 Transdução das Células-Tronco do Epitélio Olfatório com Lentivírus

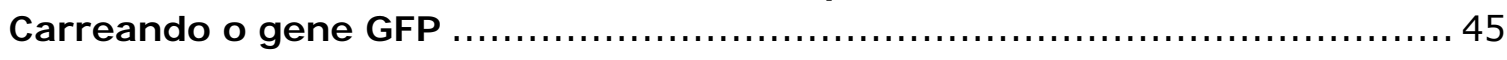

4.1.5 Cell Sorting das Células Tronco de Epitélio Olfatório de Coelhos

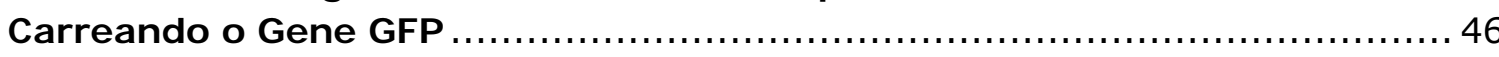

4.1.6 Preparação de Células-Tronco Transduzidas para Transplante nos

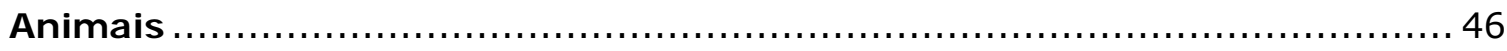

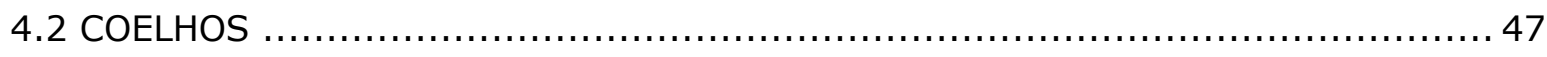

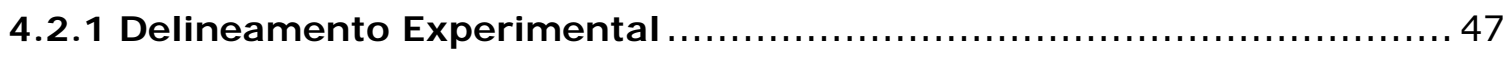

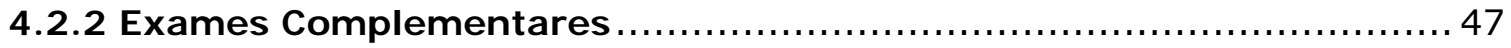

4.2.3 Padronização da Técnica de I ndução da Lesão Medular por

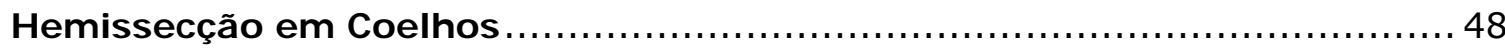

4.2.4 Cuidados Pós-Operatórios após a I ndução da Lesão Medular ............. 50

4.2.5 Protocolo de Eutanásia e Coleta de Material para Avaliação Histológica 51

4.2. 6 Técnica de Coloração em Hematoxilina e Eosina. 52

4.2.7 I dentificação da Proteína Verde Fluorescente (Green Fluorescent Profein - GFP) e da expressão de Glial Fibrilary Acid protein (GFAP) e de 
Sulfato de Condroitina Proteoglicano (SCPg) na Lesão Medular de Coelhos

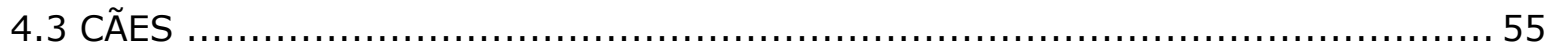

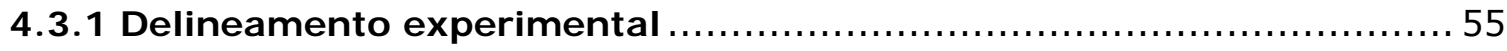

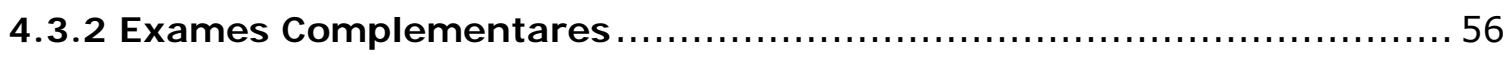

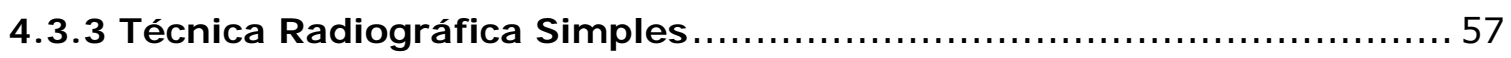

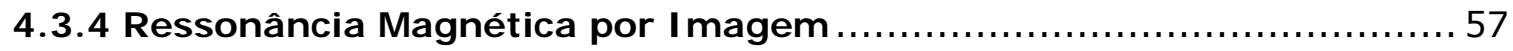

4.3.5 Técnica Anestésica e Cirúrgica para Descompressão da Medula Espinhal dos Cães e Transplante das Células-Tronco da Polpa Dentária

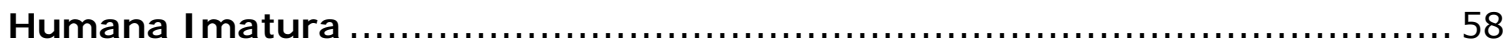

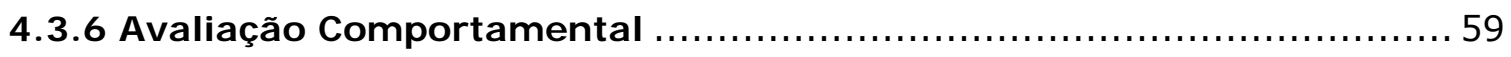

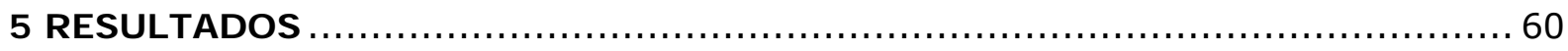

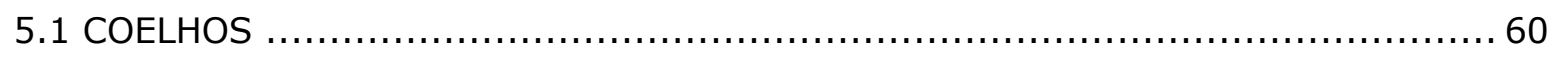

5.1.1 I ndução da Lesão Medular por Hemissecção em Coelhos................60

5.1.2 Terapia Celular com Células-Tronco do Epitélio Olfatório de Coelhos . 68

5.1.3 Avaliação histológica e imunohistoquímica dos coelhos submetidos à

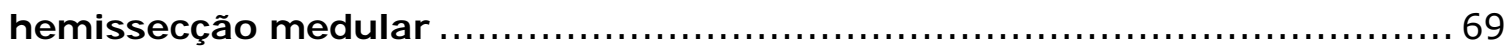

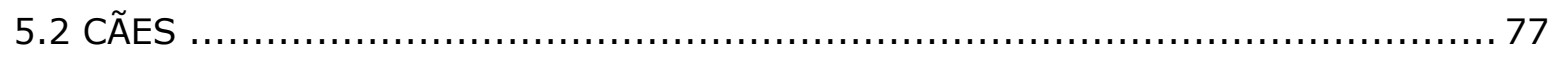

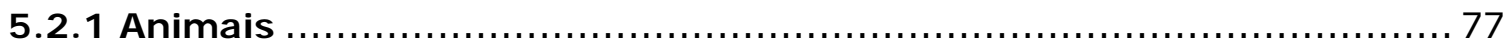

5.2.2 Exames complementares pré-operatórios ............................ 77

5.2.3 Transplante de Células Tronco da Polpa Dentária Humana I matura em

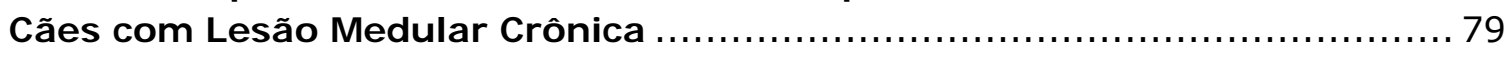

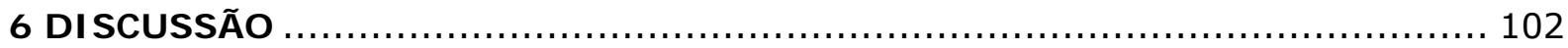

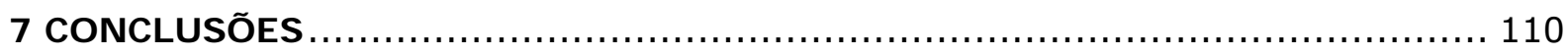

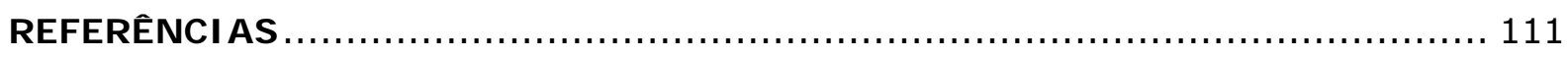

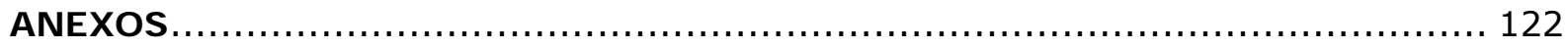




\section{I NTRODUÇÃO}

Somente nos Estados Unidos as lesões medulares afetam de 3 a 5 pessoas em cada 100000, com números bastante similares em outros países (OLSON, 2002). São acometidos principalmente adultos jovens em decorrência de acidentes automobilísticos.

Ramon Y Cajal (1928) foram os primeiros a afirmarem que as células do sistema nervoso central possuíam capacidade limitada de regeneração. Somente cindo décadas após foram questionados por Richardson et al. (1980). Estes autores realizaram um ensaio em ratos, onde axônios da medula espinhal eram retirados e inseridos no sistema nervoso periférico. Os mesmos constataram que as dificuldades de regeneração das células nervosas do SNC estavam claramente relacionadas ao nicho celular de origem das mesmas.

O processo regenerativo de danos sofridos ao sistema nervoso central (SNC), e em especial a medula espinhal, apresenta alguns fatores limitantes, tais como a produção de inibidores de crescimento dos axônios e a formação da cicatriz glial (OLSON, 2002).

Modelos animais são importantes ferramentas para o estudo de patologias associadas com doenças específicas, além de servirem como um sistema no qual podem ser testadas, novas terapias (CAPECCHI, 1989). A possibilidade de restaurar a função de células e tecidos sem a necessidade de utilização de drogas imunossupressoras e sem a 
preocupação com a compatibilidade tecidual torna as células-tronco, especialmente as pluripotentes, uma forte promessa para o tratamento de doenças devastadoras (SOUZA et al, 2003). É possível afirmar que a terapia celular com o uso de células tronco pode tornar-se mais eficaz que algumas alternativas terapêuticas, tais como transplantes e fármacos.

Um grande número de estudos tem sido realizado com célulastronco de diferentes fontes em diferentes modelos animais de lesão medular, e até mesmo tentativas terapêuticas em humanos, apresentando resultados promissores (IWANAMI et al., 2005; LEE et al., 2007; LIM et al., 2007; MACKAY-SIM et al., 2008). Há alguma dificuldade na comparação direta desses trabalhos, devido ao grau variável de caracterização das células transplantadas, diferentes modelos animais e a variação do tempo entre a ocorrência da lesão e o tratamento (BARNABÉ - HEIDEN; FRISÉN, 2008).

Cães apresentam rotineiramente na clínica afecções da medula espinhal toracolombar, causada principalmente por herniação de discos intervertebrais (SEIM, 1996). O canal medular toracolombar dos cães é bastante estreito, e a ocorrência de hérnia toracolombar pode levar a paralisia completa dos membros pélvicos com perda de sensibilidade e da função motora (PADILHA FILHO; SELMI, 1999).

Animais com paralisia dos membros, mas que tenham ainda sensibilidade profunda preservada são candidatos à cirurgia descompressiva (descompressão ventral, hemilaminectomia e facetectomia lateral, laminectomia dorsal) ou a fenestração dos discos 
intervertebrais. Animais com perda da sensibilidade dolorosa profunda há mais de 48 horas, não são considerados candidatos à cirurgia devido à falta de expectativa de retorno à função locomotora (KNECHT, 1972).

Há relatos consistentes de recuperação funcional em ratos com lesão medular tratados com células tronco mesenquimais (MSCMesenchymal Stem Cells) (HOFSTETTER et al., 2002; LEE et al., 2007). Estes tipos celulares "não neurais" apresentam um mecanismo diferente para a recuperação das lesões medulares onde não há a reposição de neurônios ou de células da glia (BARNABÉ-HEIDEN E FRISÉN, 2008). É bem provável que estes tipos de células forneçam suporte trófico, modulem a resposta inflamatória ou forneçam substratos para o crescimento de axônios, como eixos orientadores para a regeneração medular, promovendo a recuperação funcional (HOFSTETTER et al., 2002).

As células-tronco ideais para a realização de transplantes devem ser imunologicamente inertes, provenientes de fontes de fácil acesso, possuir rápida expansibilidade em cultivo, apresentar capacidade de sobrevivência em longo prazo e de integração no sítio hospedeiro além de serem propícias a transfecção e expressão de genes exógenos (AZIZI et al., 1998).

A polpa dentária de dentes decíduos surge como fonte alternativa para obtenção de MSC, apresentando grande potencial para uso em ortopedia, devido a características únicas como: fácil obtenção de material 
para cultivo celular, extração eficiente, alta habilidade de diferenciação e boa interatividade com biomateriais (D'AQUINO et al., 2008).

A polpa dentária humana é uma fonte de MSC derivadas da crista neural, recentemente descoberta, e com possibilidades terapêuticas promissoras. Gronthos et al. (2002) estudaram a capacidade de autoregeneração, de diferenciação em multi-linhagem e a eficiência clonogênica das células-tronco da polpa dentária em humanos. Eles relataram à capacidade de diferenciação destas células em adipócitos e células nervosas.

Kerkis et al. (2006) relataram o isolamento e caracterização, através de diversos marcadores de células-tronco de origem embrionária, de células-tronco de polpa dentária humana imatura (human immature dental pulp stem cells - h-IDPSC). Os autores diferenciaram essas células em músculo liso e estriado, osso, cartilagem e neurônios em condições de cultivo pré-definidos, sugerindo a utilização destas células em ensaios préclínicos.

Estudos focando as células-tronco do epitélio olfatório especulam sobre o possível potencial de regeneração axonal e cura de doenças demielinizantes (MARSHALL et al., 2006). Mackay-Sim et al. (2008), após um ensaio clínico de 3 anos com o transplante autólogo de células-tronco do epitélio olfatório em humanos, constatou não haver nenhuma alteração patológica ou formação de tumores após o transplante, embora também não tenham encontrado melhora clínica relevante nos pacientes tratados. 
A evolução biotecnológica, através da engenharia genética, vem possibilitando o desenvolvimento de vetores para a transferência de genes cada vez mais seguros e de fácil produção em grande escala e eficientes nos processos de transfecção e transdução in vitro ou in vivo.

Apesar de haverem muitos trabalhos referentes à terapia celular em modelos animais, pouca informação existe sobre como as célulastronco transplantadas de fato participam do processo regenerativo da lesão, e se de fato as células sobrevivem ao processo de transplante (HASSAN; EL-SHEMEMY, 2004).

Hannouche et al. (2007) relatam que células-tronco mesenquimais de medula óssea transplantadas em tecido esquelético de camundongos foram capazes de expressar um gene repórter (LacZ) por mais de 4 semanas, além de repararem e vascularizarem o osso defeituoso in vivo.

Ueblacker et al. (2007) realizaram análise in vivo da transferência do gene retroviral LacZ para condrócitos utlizando colágeno como veículo para o tratamento de defeitos osteocondrais. Após 4 semanas de implante foi possível observar a expressão da $\beta$-Galactosidase intra-articular na maioria dos condrócitos implatados através da fixação com X-Gal.

Desta forma, os marcadores retrovirais podem ser uma ferramenta bastante útil para o rastreamento das células-tronco após o transplante em modelos animais, confirmando o sucesso do transplante e possibilitando avaliar a real interação das células transplantadas com o nicho celular em que se encontra. 


\section{J USTI FI CATI VA}

Tendo em vista o crescente número de trabalhos envolvendo a utilização de células-tronco na lesão medular, tanto em animais como em humanos, com resultados clínicos animadores, realizou-se este estudo que teve como objetivo fornecer mais dados e subsídios para a terapia celular em humanos, utilizando modelos animais. A utilização de cães portadores da lesão medular crônica espontânea é um diferencial desse trabalho, bem como a utilização de coelhos para rastreamento das células transplantadas e compreensão dos eventos que acompanham esta terapia celular. 


\section{REVI SÃO DE LITERATURA}

\subsection{LESÃO MEDULAR}

A lesão medular é uma doença devastante, que afeta sobremaneira tanto humanos como os animais, levando a danos tanto físicos quanto psicológicos. Na medicina humana, de três a cinco pessoas em cada 100000 pessoas, são acometidas por esse mal, anualmente (OLSON, 2002).

As lesões medulares são frequentes na medicina veterinária, tanto oriundas de traumas, quando de discopatias (SEIM, 1996).

A lesão medular traumática em cães resulta de trauma endogéno (Hérnia de disco intervertebral) e exógeno (acidentes com carros). Independente da causa, as lesões medulares possuem mecanismos de lesão primário e secundário. Os mecanismos da lesão primária são resultados da injúria física a medula espinhal, resultando em laceração, contusão, compressão, e tração do tecido neural. As mudanças patológicas resultantes dos mecanismos de injúria primários envolvem lesão axonal, dano mecânico direto as células, e vasos sanguíneos rompidos (WEBB et al., 2010).

Os mecanismos de injúria secundários a lesão medular envolvem distúrbios eletrolíticos, perda da regulação da pressão local e sistêmica, 
redução do fluxo sanguíneo da medula espinhal, quebra da barreira hematoencefálica, produção de radicais livres, desequilíbrio das metaloproteinases ativadas e emissão de neurotransmissores citotóxicos (TATOR et al. 1991; KRASSIOUKOV; CLAYDON, 2006).

Um dos mecanismos fundamentais iniciados pelo trauma dos SNC é a interrupção na homeostase celular do $\mathrm{Ca}^{+2}$. Como esse íon possui função fudamental em inúmeras das funções celulares, seu desequilíbrio causa grande distúrbio homeostático e acaba levando à degeneração axonal, produzindo debilidade clínica (TYMIANSKI et al., 1996).

O processo regenerativo de danos sofridos ao sistema nervoso central (SNC), e em especial a medula espinhal, apresenta alguns fatores limitantes, tais como a capacidade limitada do SNC em repor as células danificadas (JOHANSSON et al., 1999) e a produção de inibidores de crescimento dos axônios associados com mielina e a formação da cicatriz glial (OLSON, 2002).

A cicatriz glial é constituída predominantemente de astrócitos reativos, micróglia/macrófagos e moléculas da matriz extracelular, especialmente de sulfato de condroitina proteoglicana (SCPG) (ROLLS et al., 2008). Os efeitos inibitórios do tecido cicatricial são considerados como o principal empecilho a regeneração do tecido nervoso. Vários trabalhos demonstram a utilização de substâncias e enzimas que eliminam ou reorganizam a cicatriz glial e também com ressecção cirúrgica da cicatriz da glia, onde têm se destacado o uso da condroitinase $A B C$, uma substância que atua principalmente na eliminação da cicatriz da glial, em 
qualquer época da sua formação (JONES et al., 2003; SHIELDS et al., 2008; RASOULI et al., 2009; ROLLS et al., 2008; TOM; HOULÉ, 2008).

Apesar de apontada como a grande vilã da regeneração das lesões medulares, estudos recentes demonstraram vários efeitos benéficos desta cicatriz nas primeiras duas semanas após a lesão medular (ROLLS et al., 2008). A eliminação dos astrócitos reativos, ou a prevenção da migração dos mesmos após a lesão medular resulta em falhas no processo de recuperação da barreira hemato-encefálica, acompanhada por infiltração celular massiva e aumento da perda de neurônios e oligodendrócitos (OKADA et al., 2006).

A resposta astrocítica pode ser importante para limitar a resposta inflamatória, porém, isso pode ser feito a custa de uma rebrota axonal bastante reduzida. A cicatriz da glia reduz a possibilidade das células enxertadas para migrarem e se integrar. A maioria dos estudos com terapia celular está limitada em estudar os efeitos do transplante celular em 1-2 semanas após a lesão (OGAWA et al., 2002). É difícil prever os resultados da terapia celular na lesão medular crônica.

\subsection{CÉLULAS-TRONCO DA POLPA DENTÁRIA HUMANA}

A polpa dentária humana é uma fonte de MSC recentemente descoberta, e com possibilidades terapêuticas promissoras. 
Gronthos et al., (2002) isolaram uma população clonogênica e proliferativa de células da polpa dentária humana. Os autores caracterizaram imunofenotipicamente estas células e compararam as MSC da polpa dentária com as MSC de medula óssea, julgando haver semelhanças marcantes entre as mesmas. Estes pesquisadores ainda estudaram a capacidade auto regenerativa, capacidade de diferenciação em multi-linhagens e a eficiência clonogênica das células-tronco da polpa dentária em humanos. Os autores relataram a capacidade de diferenciação destas células em adipócitos e células com aspecto neural.

Kerkis et al., (2006) relataram o sucesso do isolamento de uma população de hIDPSC ( human- Immature Dental Pulp Stem cells) de dentes decíduos não esfoliados. Em condições de cultivo, estas células mostraram-se hábeis a expressar tanto fatores transcripcionais de células tronco embrionárias (Oct-4 e Nanog) bem como marcadores de superfície de células tronco mesenquimais (CD 105, CD73 e CD13). Entretanto, não expressaram os macadores CD45, CD34, CD14, CD43, and of HLA-DR. Estas células são hábeis para se diferenciarem de forma espontânea ou induzida em osteoblastos, adipócitos e condroblastos, células musculares, e até mesmo neurônios in vitro. Após transplante em camundongos normais, estas células mostraram uma boa interação no fígado, baço, cérebro e rins, além de outros.

Otaki et al., (2007) injetaram células-tronco de polpa dentária humana no subcutâneo de ratos imunocomprometidos, usando como veículo pó de hidroxiapatita e fosfato tricálcico, retirando os implantes 
com 7 e 15 semanas. Os autores relatam a formação de osso ao invés de dentina no subcutâneo dos ratos, e concluem que a polpa dentária humana deve ser utilizada com finalidades terapêuticas para recuperação de tecidos danificados.

Kerkis et al. (2008) demonstraram a efetividade do transplante das hIDPSC em cães GRMD (Golden Retriever Muscular Dystrophy). Quatro cães com idade entre 28-40 dias, receberam injeções destas células por via intra-arterial (artéria femoral) ou por via intramuscular. Dois animais da mesma ninhada não foram injetados, constituindo o controle desse experimento. Os animais foram avaliados clinicamente através de exames de sangue para averiguar as reações imunes, e também foram avaliados através de escores corporais, realizados em todos os cães. Amostras de biópsia foram colhidas para análise imunohistoquímica (marcadores de distrofina) e fluorescência por hibridização in vitro (FISH - Fluorescent in situ hibridisation) humana. Fibras musculares quiméricas foram detectadas por imunofluorescência e por FISH usando anticorpos humanos e e probes $\mathrm{X}$ e $\mathrm{Y}$ de DNA. Não houveram sinais de rejeição às células nos animais transplantadas, o que sugere que o tratamento com hIDPSC pode ser realizado mesmo sem imunossupressão. Os autores demosntraram que as células possuíram uma boa interação com as células musculares dos cães GRMD, entretanto, a liberação de distrofina foi discreta, e restrita a algumas fibras musculares.

Beltrão-Braga et al. (2011) conseguiram reprogramar hIDPSC fazendo estas células retornarem ao seu estado embrionário, produzindo 
uma cultura primária de h-IDPSC-iPSC (induced pluripotent stem cells). No entanto estas células apresentaram grande potencial teratogênico quando implantadas em camundongos imunossuprimidos, o que invalida a utilização destas células para a terapia celular.

\subsection{CÉLULAS-TRONCO DO EPITÉLIO OLFATÓRIO}

O epitélio olfatório é tido como uma das mais promissoras fontes para obtenção de células-tronco de origem neural, possuindo características únicas, devido a proximidade com as áreas mais nobres do sistema nervoso central (SNC), além da possibilidade de serem facilmente obtidas em humanos por meio de biópsia através das narinas externas (BIANCO et al., 2004).

Após uma lesão, ou durante a reposição celular fisiológica (normal cell turnover) novos receptores neuronais olfatórios são gerados por células troncos na camada basal do epitélio olfatório, emitindo prolongamentos de axônios que atravessam o platô cribiforme e adentram o bulbo olfatório realizando sinapses com neurônios de segunda ordem na camada glomerular (SCHWAB, 2002). Essa é uma das raras ocasiões em que neurônios periféricos são hábeis a adentrar no ambiente do SNC e realizar sinapses, e essa habilidade não usual é atribuída às propriedades especializadas das células tronco do epitélio olfatório (DOUCETTE, 1990). 
Pagano et al., (2000) demonstraram que populações altamente enriquecidas com progenitores neuronais podem derivar a partir de céulas-tronco embrionárias. Tais progenitores neuronais são capazes de extensivas proliferações in vitro, enquanto guardam o potencial para se diferenciar em pelo menos três linhagens neuronais fudamentais do sistema sensorial dos mamíferos.

Segundo Lu e Ashwell (2002), as células-tronco olfatórias dão suporte aos axônios olfatórios da lâmina própria até o bulbo olfatório mielinizando axônios desmielinizados ou em regeneração. Os autores revelaram que essas células fornecem um substrato muito favorável para a regeneração axonal, pois secretam matriz extracelular e fatores neurotróficos. Sua habilidade de migrar pelo tecido lesado ou já recuperado após o transplante é maior se comparada com outros tipos celulares (AUDÍSIO et al. 2009).

\subsection{TERAPIA CELULAR NA LESÃO MEDULAR}

Durante muito tempo, devido ao conceito de não regeneração das células nervosas (RAMON Y CAJAL, 1928), a terapia direcionada a lesão medular era considerada não curativa, e tinha como finalidade apenas diminuir a inflamação causada pela injúria tecidual, nas lesões medulares 
agudas. Nos casos subagudos e crônicos o tratamento é focado no alívio dos sintomas (alívio de dor e infecções) e fisioterapia (BAPTISTE \& FEHLINGS, 2007). O campo da terapia celular, e das células-tronco evoluiu bastante e surge como uma nova esperança para os lesados medulares.

Nosrat et al., (2001) avaliaram o potencial neurogênico das células da polpa dentária in vitro, e em ratos submetidos a hemisecção medular. Os autores afirmam que as células de polpa de dente produzem diversos fatores neurotróficos em cultivo, e quando cultivadas com neurônios trigeminais promovem a sobrevivência e um específico e elaborado a partir dos neurônios trigeminais, o mesmo não acontecendo com fibroblastos de pele. A enxertia dessas células em ratos com medula hemisseccionada aumentou o número de neurônios motores sobreviventes, indicando uma bioatividade funcional.

Células-tronco do epitélio olfatório humano foram utilizadas em 7 pacientes com idade de 18-32 anos com gradação da American Spinal Injury Association como ASIA A. A via escolhida para injeção das células foi a via local, diretamente no foco da lesão medular. Avaliação por ressonância magnética, eletromiografia, sistema de avaliação neurológico ASIA, e avaliações otorrinolaringologistas foram realizados antes e depois da cirurgia. Dois dos sete pacientes apresentaram melhora no quadro de ASIA A para C, retornando a sensação da bexiga dos dois, e retornando o reflexo de contração do esfíncter anal em um dos pacientes. O estudo 
demonstrou que o procedimento é factível, relativamente seguro e pode ser potencialmente benéfico (LIMA et al., 2006).

Paul et al., (2009) realizaram estudos de três vias de aplicação das células-tronco mesenquimais: punção lombar ( $P L)$, intravenosa (IV) e diretamente no local da lesão medular. Apesar da PL ter sido superior a via IV, a via local é, sem sombra de dúvidas, a via mais eficaz para a enxertia das células-tronco mesenquimais. Desta forma a via local nesse experimento foi utilizada apenas como controle para as demais vias estudadas.

Demais estudos em animais apresentam melhora clínica significativa após a utilização das células-tronco na lesão medular (LEE et al., 2007; LIM et al., 2007; CAO; FENG et al., 2009). Entretanto, os estudos em humanos, apresentam resultados pífios, ou mesmo inexpressivos.

Mackay-Sim et al., (2008) realizaram estudos em 12 pacientes humanos com lesão medular crônica, fazendo a aplicação de células do epitélio olfatório por via local. Apenas um paciente apresentou alguma melhora clínica, e os autores concluíram que o transplante dessas células na medula espinhal é um procedimento factível e seguro, apesar do " $n$ " reduzido. 
3.5 USO DE VETORES RETROVIRAIS NO RASTREAMENTO PÓSTRANSPLANTE

A evolução biotecnológica, através da engenharia genética, vem possibilitando o desenvolvimento de vetores para a transferência de genes cada vez mais seguros, de fácil produção em grande escala e eficientes nos processos de transfecção e transdução in vitro ou in vivo.

Pouca informação existe sobre como as células-tronco transplantadas de fato participam em um processo regenerativo, e quantas células de fato sobrevivem após transplante (HASSAN; ELSHEMEMY, 2004).

A fluorescência endógena das células do epitélio olfatório, permitida pela ação da proteína fibrilar verde (GFP), promove uma marcação celular que facilita sua identificação quando transplantada em hospedeiros não-transduzidos. Essa marcação com GFP oferece um modelo útil para análise do potencial terapêutico dos progenitores de epitélio olfatório em doenças degenerativas e neurotraumas (OTHMAN, 2003).

Células-tronco neuronais reconhecidas pela expressão do gene repórter Lac-Z puderam ser identificadas em estudos de neuroregeneração do sistema nervoso central de ratos (PARK et al, 2006).

Hannouche et al. (2007), relataram que células-tronco mesenquimais de medula óssea transplantadas em tecido esquelético de 
camundongos foram capazes de expressar um gene repórter (LacZ) por mais de 4 semanas, além de reparem e vascularizarem o osso defeituoso in vivo.

Ueblacker et al. (2007) realizaram análise in vivo da transferência de gene retroviral para condrócitos utlizando colágeno como veículo para o tratamento de defeitos osteocondrais. Após 4 semanas de implante foi possível observar a expressão da $\beta$-galactosidase intra-articular na maioria dos condrócitos implatados através da fixação com X-Gal. 


\section{MATERI AL E MÉTODOS}

Este experimento está de acordo com os princípios éticos de experimentação animal da "Comissão de ética no uso de animais" da Faculdade de Medicina Veterinária e Zootecnia da Universidade de São Paulo, protocolado sob o no 2081/2010, tendo sido aprovado em reunião de $16 / 02 / 2011$.

O mesmo experimento também foi submetido ao "Comitê de ética de ética na experimentação animal da FZEA/USP", tendo sido avaliado por profissionais da área, e sendo considerado aprovado, em carta emitida em 21 de setembro de 2010 .

\subsection{CULTIVO MANEJO E TRANSDUÇÃO DAS CÉLULAS-TRONCO UTILIZADAS}

\subsubsection{Cultivo das h-I DPSC}

Foram utilizadas células imaturas de polpa de dente obtidas segundo descrito por Kerkis et al. (2006). Estas células encontram-se criopreservadas e disponíveis no Laboratório de Células Tronco (LCT) da 
Universidade de São Paulo (USP), sendo assim, a manutenção, expansão in vitro e diferenciação seguiram os protocolos já desenvolvidos por essa equipe, que correspondem em cultivar as células no meio Dulbecco's modified Eagle's medium (DMEM)/Ham's F12 (1:1, Invitrogen, Carlsbad, Calif., USA), contendo $15 \%$ de soro fetal bovino (FBS, HyClone, Logan, Utah, USA), $100 \mathrm{U} / \mathrm{ml}$ de penicilina, $100 \mu \mathrm{g} / \mathrm{ml}$ de estreptomicina, $2 \mathrm{mM}$ de Lglutamina e 2mM de aminoácidos não essenciais.

\subsubsection{I solamento e Cultivo das Células Tronco do Epitélio Olfatório de Coelhos}

Foram utilizados coelhos da linhagem Nova Zelândia com idade aproximada de um ano, pesando entre 2,5 a $3 \mathrm{Kg}$, obtidos em granja especializada na produção de animais utilizados em pesquisa experimental (Granja RG - Comércio de Produtos Agropecuários Ltda. ME-São PauloSP). Após contenção física, os coelhos receberam uma dose de $35 \mathrm{mg} / \mathrm{kg}$ de cetamina associado a $2 \mathrm{mg} / \mathrm{kg}$ de midazolam, tendo a veia auricular posteriormente canulada com catéter 24G para administração de 100 $\mathrm{mg} / \mathrm{kg}$ de tiopental sódico por via intravenosa, até a completa parada cardíaca confirmada através de auscultação. 
Após excisão da cabeça dos animais e remoção de pele e pêlos realizou-se cuidadosa higienização em água destilada para remoção de componentes sanguíneos e impurezas com potencial de contaminação.

Em seguida, o material foi transportado ao Laboratório de Cultivo Celular do Departamento de Cirurgia do Setor de Anatomia dos Animais Domésticos e Silvestres da Faculdade de Medicina Veterinária e ZootecniaUSP. Os procedimentos subseqüentes foram realizados dentro de Fluxo Laminar.

No fluxo laminar foi realizado acesso a região do epitélio olfatório através de corte sagital do crânio dos animais. Em seguida foram coletados fragmentos do epitélio olfatório e depositados em placa de Petri e lavados cinco vezes com PBS acrescido de penicilina-estreptomicina a 3\% (Invitrogen, Cat. No 15140-122) para remoção de possíveis elementos contaminantes, como pêlos ou sangue remanescente, durante cinco minutos sendo trocadas de placa a cada lavagem.

Após o processo de descontaminação, com as sucessivas lavagens com PBS foi realizada dissociação química com $1 \mathrm{~mL}$ de Tripsina Triple Express (Invitrogen, Cat. $\mathrm{N}^{\circ} 12604$ ), durante 5 minutos. Para aperfeiçoar o processo de liberação das células olfatórias a partir dos fragmentos teciduais, realizou-se simultaneamente a dissociação mecânica.

Segue-se ao procedimento de dissociação a encubação do material em estufa a $37^{\circ}$ Celsius e $5 \% \mathrm{CO}_{2}$ por 15 minutos.

Subseqüente análise das células liberadas foi realizada com o auxilio de microscópio óptico de luz invertida NIKON Eclipse-TS 100 sob objetivas 
de $4 x$ e 10x. As imagens obtidas foram armazenadas através do sistema de captura ENLTV 8.0.7.

Após ter sido constatada uma grande quantidade de células livres dos fragmentos teciduais, realizou-se a inativação da Tripsina com a adição de $2 \mathrm{~mL}$ do meio de cultivo. Pôde-se observar a sedimentação dos fragmentos coletados após 5 minutos de descanso. Então o sobrenadante foi separado, ressuspendido em $3 \mathrm{~mL}$ de meio de cultivo e transferido para um tubo de polipropileno de $15 \mathrm{ml}$ com $5 \mathrm{~mL}$ de meio de cultivo. Em seguida os tubos foram centrifugados por 1000rpm a 5 minutos.

Após centrifugação os fragmentos e células suspensas foram ressuspendidas em $1 \mathrm{~mL}$ de meio de cultura e o material transferido para garrafas de $25 \mathrm{~cm}^{2}$ (TPP, Switzerland) onde foi colocado em cultivo em estufa contendo $\mathrm{CO} 2-95 \%$ à $37^{\circ} \mathrm{C}$. As imagens das células postas em cultura serão obtidas em microscópio de luz invertida (NIKON Eclipse-TS 100) com objetivas de $4 x, 10 x, 20 x$ e $40 x$ e armazenadas através de sistema de captura (MTC Digital Color Camera).

O meio de cultivo utilizado continha $82 \%$ de D MEN-F12 (LGC, Cat. $\mathrm{N}^{\circ}$ BR-30004-05), 15\% de soro fetal bovino (Hyclone, Cat. $\mathrm{N}^{\circ} \mathrm{SH} 30070-$ 03), $1 \%$ de L-glutamina (Sigma, Cat. $\mathrm{N}^{0}$ G7513), 1\% de PenicilinaEstreptomicina (Hyclone, Cat. $\mathrm{N}^{\circ} \mathrm{SH} 40003-12$ ), e 1\% de MEN NEAA (Invitrogen, Gibco, Cat. N ${ }^{\circ} 11140$ ). 


\subsubsection{Produção das Células HEK 293T produtoras de lentivírus}

Estas células foram adquiridas da empresa Sigma-Aldrich. As células HEK $293 T$ é uma linhagem permanente estabelecida do rim embrionário primário de humano, transformada com adenovírus tipo 5.0 gene E1A do adenovírus é expresso nestas células e participa na transativação de alguns promotores virais, permitindo que estas células produzam altos níveis de proteína. Desta forma, esta linhagem celular torna-se um hospedeiro susceptível para a produção de lentivírus.

As células HEK 293T foram plaqueadas na concentração de 3,33 X 106 em $11 \mathrm{~mL}$, em garrafas de $75 \mathrm{~cm} 2$, na temperatura de $38.5^{\circ} \mathrm{C}$. $\mathrm{O}$ meio de cultivo era constituído de meio de Eagle modificado de Dulbecco (DMEM) com alta glicose, $10 \%$ de soro fetal bovino não inativado, $6 \mathrm{mM}$ de glutamina, $1 \mathrm{mM}$ de piruvato, 0,1 mM de MEM - aminoácidos não essenciais e $84 \mu \mathrm{g} \cdot \mathrm{mL}-1$ de amicacina. No segundo dia de cultivo, o meio de cultivo era retirado e substituído com o mesmo meio, acrescido de $500 \mu \mathrm{g} \cdot \mathrm{mL}-1$ de geneticina. As células eram então crescidas até atingirem a confluência de $80 \%$ a $90 \%$, por um período de 3 a 4 dias de cultura. Neste ponto, as células eram tripsinizadas e utilizadas no experimento de cotransfecção.

Os experimentos de cotransfecção foram realizados pelo método de lipofecção. Inicialmente, foi adicionado $36 \mu \mathrm{L}$ de lipofectamina 2000 (Invitrogen) em 1,5 $\mathrm{mL}$ de DMEM sem soro fetal bovino. Em outro tubo 
contendo $1,5 \mathrm{~mL}$ de DMEM, sem soro fetal bovino, foi adicionado $3 \mu \mathrm{g}$ do vetor construído e $9 \mu \mathrm{g}$ da mistura dos vetores pLP1, pLP2 e pLP/VSVG (ViraPower packaging mix - Invitrogen). Os tubos contendo lipofectamina e os vetores foram gentilmente agitados e incubados durante 5 minutos a temperatura ambiente. Após este período de incubação, o DMEM contendo período de incubação, a cultura de célula HEK 293T foi tripsinizada e as células ressuspendidas na concentração de $1,2 \times 106$ por $\mathrm{mL}$ em meio de cultivo das células HEK 293T. Os complexos dos vetores e lipofectamina foram adicionados em placa de $100 \mathrm{~mm}$, contendo $5 \mathrm{~mL}$ de meio de célula HEK 293T, e em seguida, adicionado $5 \mathrm{~mL}$ da suspensão de células, dando um total de $6 \times 106$ células. A placa foi homogeneizada suavemente e incubada durante a noite toda. No segundo dia, o meio era retirado e colocado $10 \mathrm{~mL}$ de meio de cultivo das células HEK 293T. Após 48 horas da transfecção, o meio era coletado, centrifugado a $80 \mathrm{~g}$ durante 3 minutos para a peletização dos debris celulares. O sobrenadante era filtrado em filtros de $0.45 \mu \mathrm{m}$, alicotados e estocados a $-80^{\circ} \mathrm{C}$ para posterior experimento de transdução. Em todas as etapas não foi utilizado o antibiótico geneticina.

Os experimentos de cotransfecção foram realizados de forma individual para cada vetor construído (pLenti-Pßcas3-GFP, pLentiPßcas4-GFP， pLenti-Pßcas5-GFP， pLenti-Pßcas3-FIX，pLenti-Pßcas4-FIX e pLenti-PBcas5-FIX). 


\subsubsection{Transdução das Células-Tronco do Epitélio Olfatório com Lentivírus Carreando o gene GFP}

Uma alíquota de cada extrato viral, produzidos a partir da célula HEK 293T foram descongelados e receberam polibreno. Essa substância é usada para redução da tensão superficial que viabilizará a infecção das células em cultivo com os lentivírus. O meio de cultivo das placas com células-tronco olfatórias foi descartado e adicionado o extrato viral juntamente com $1 \mathrm{~mL}$ de meio novo em cada placa. A partir de $48 \mathrm{~h}$ adicionou-se blasticidina, um antibiótico de seleção que é tóxico para células eucariontes visto que inibe sua síntese de proteínas. O vírus possui resistência a blasticidina, de modo que as células infectadas não foram destruídas. Esse tratamento com antibiótico foi realizado por aproximadamente 10 dias com administração da blasticidina de 3 em 3 dias, para eliminação completa de células não infectadas. Ao final do décimo dia o meio de cultivo foi trocado e observou-se o início da multiplicação das células transgênicas em cultivo. A análise da expressão do gene exógeno GFP foi realizada mediante a exposição das células em cultivo com um feixe de luz polarizada. 


\subsubsection{Cell Sorting das Células Tronco de Epitélio Olfatório de Coelhos Carreando o Gene GFP}

As células-tronco olfatórias de coelho na terceira passagem do cultivo foram submetidas à técnica de citometria de fluxo (FACS fluorescence assisted cell sorting), a fim de avaliar a eficácia da transdução e separar e coletar as células positivas (sorting), continuando um cultivo com alto grau de pureza da população GFP-positiva. As análises foram conduzidas em citômetro FACSAria (Becton, Dickinson and Company) e analisadas em software FACSDiva Version 6.1.1. A GFP é excitada com o laser a 488nm (laser azul) e a emissão é captada pelo filtro 530/30nm. Células não transduzidas foram utilizadas como células controle. As células foram tripsinizadas, centrifugadas a $1200 \mathrm{rpm}$ por 5 minutos e ressuspendidas em meio de cultivo próprio suplementado com $10 \%$ de soro fetal e antibióticos. Foram adquiridas 10.000 células para as análises estatísticas, e para o sorting, foram recuperadas todas as células positivas em cultivo.

\subsubsection{Preparação de Células-Tronco Transduzidas para Transplante nos Animais}

Células transduzidas em cultivo foram homogeneizadas e centrifugadas sob refrigeração a $1000 \mathrm{rpm}$ por 7 minutos. O precipitado 
celular foi ressuspendido com PBS e centrifugado a $1000 \mathrm{rpm}$ por 7 minutos. Essa lavagem com PBS foi realizada duas vezes com o intuito de remover traços de SFB. Após a contagem das células, $5 \times 10^{5}$ célulastronco do epitélio olfatório foram ressuspendidas em $0,2 \mathrm{~mL}$ de PBS para serem inoculadas nos coelhos experimentais.

\subsection{COELHOS}

\subsubsection{Delineamento Experimental}

Seis coelhos da raça Nova Zelândia foram utilizados em dois grupos de três animais cada, experimental e controle. Todos os animais tiveram a medula seccionada através da técnica de hemissecção ventral descrita posteriormente. Os animais pertencentes ao grupo experimental após a lesão medular foram submetidos à terapia celular com células do epitélio olfatório de coelhos transduzidas com o gene repórter GFP.

\subsubsection{Exames Complementares}

Os coelhos utilizados neste experimento foram adquiridos em criatório especializado no fornecimento de animais para a pesquisa 
científica (Granja RG produtos agropecuários Ltda-ME), todos foram atestados quanto a sua higidez, não havendo necessidade de realização de exames complementares pré-operatórios. No entanto, todos os animais passaram por um protocolo de vermifugação com $0,4 \mathrm{mg} / \mathrm{kg}$ de ivermectina, repetida com 15 dias após a primeira dose. Os animais também receberam $10 \mathrm{mg} / \mathrm{kg}$ de enrofloxacina duas vezes ao dia por via intramuscular por 5 dias, como profilático para doenças de origem bacteriana.

\subsubsection{Padronização da Técnica de I ndução da Lesão Medular por Hemissecção em Coelhos}

Foram realizadas as técnicas de hemissecção medular ventral e dorsal. Os coelhos foram contidos quimicamente com $35 \mathrm{mg} / \mathrm{kg}$ de cloridrato de quetamina e $2 \mathrm{mg} / \mathrm{kg}$ de maleato de midazolam por via intramuscular (IM). Posteriormente os animais foram colocados com o pescoço em estendido dorsalmente e intubados com sonda endotraqueal 2,5 sendo mantidos com isoflurano diluído em $\mathrm{O}^{2}$ a $100 \%$, em sistema aberto do tipo "baraka". A veia auricular foi canulada para administração de fluidoterapia intravenosa trans-operatória com solução salina de $\mathrm{NaCl}$ a 0,9\%. A artéria auricular central também foi canulada para monitoração da pressão arterial média (PAM) dos animais. Logo após tricotomia e antissepsia de rotina uma incisão media da linha dorsal será realizada. A 
lâmina, processos espinhosos e os processos transversos de T10-T11 foram gentilmente expostos através de afastamento dos músculos paravertebrais. Um afastador auto-estático de Golpi foi utilizado e os processos espinhosos das vértebras T10-11 foram removidos com auxílio de goiva e drill pneumático, sendo realizada a laminectomia dorsal das vértebras T10-11 dando visibilidade à medula espinhal. Com auxílio de um bisturi a dura máter da medula espinhal foi incisada longitudinalmente. Com uma tesoura de íris, a medula foi seccionada em sua porção dorsal ou ventral, e a dura máter foi então suturada com 3 a 4 pontos simples separados com fio de polipropileno 7-0. Os debris resultantes da lesão foram sugados delicadamente com aspirador cirúrgico. Músculos e tecidos adjacentes foram aproximados com fio absorvível (ácido poliglicólico 3-0). A pele dos animais foi aproximada com pontos simples separados de Nylon 2-0. Todos os animais experimentais tiveram a lesão medular induzida segundo o protocolo descrito. Para analgesia pós-operatória imediata foi utilizado $1 \mathrm{mg} / \mathrm{kg}$ de flunixin meglumine associado a $3 \mathrm{mg} / \mathrm{kg}$ de morfina por via IM. O pós-operatório tardio consistiu na terapia com antibiótico cefazolina 30mg/Kg/BID associada a $10 \mathrm{mg} / \mathrm{kg}$ de enrofloxacino duas vezes ao dia por 10 dias, o antiinflamatório meloxicam $0,1 \mathrm{mg} / \mathrm{Kg} / \mathrm{SID}$ por 3 dias e $3 \mathrm{mg} / \mathrm{Kg} / \mathrm{TID}$ de morfina imediatamente após a cirurgia repetida de 4 em 4 horas por mais dois dias. Imediatamente após a lesão medular, serão injetadas $1 \times 10^{6}$ células tronco do epitélio olfatório de coelhos, marcadas com o gene repórter GFP. 


\subsubsection{Cuidados Pós-Operatórios após a I ndução da Lesão Medular}

Os coelhos utilizados neste experimento foram alojados em baias individuais, com livre acesso a água e alimento durante todo o período experimental. As gaiolas destes animais foram diariamente limpas, e duas vezes os coelhos foram sondados com sonda uretral 10 e tiveram sua bexiga esvaziada, evitando dessa forma que os mesmos viessem a se urinar de forma descoordenada, contribuindo para manutenção do bem estar dos animais durante o experimento. Os animais foram avaliados clinicamente diariamente para avaliação da dor e do estado geral dos animais. Quando foi notada alteração no padrão comportamental dos animais, os mesmos foram medicados com antiinflamatório não esteroidal meloxicam $(0,1 \mathrm{mg} / \mathrm{Kg} / \mathrm{SID})$ ou com morfina $(3 \mathrm{mg} / \mathrm{Kg} / \mathrm{TID})$ de acordo com a necessidade e gravidade de cada caso. As baias dos animais foram acolchoadas com espuma, e os animais tiveram sua posição de decúbito modificada duas vezes ao dia, com a finalidade de evitar a formação de escaras. Esses animais foram eutanasiados após 20 dias da injeção das células-tronco, para colheita de tecido da medula espinhal e avaliação histológica e rastreamento do gene repórter GFP. 


\subsubsection{Protocolo de Eutanásia e Coleta de Material para Avaliação Histológica}

Os coelhos foram contidos quimicamente com $30 \mathrm{mg} / \mathrm{kg}$ de cloridrato de quetamina e $2 \mathrm{mg} / \mathrm{kg}$ de maleato de midazolam por via intramuscular (IM). Após 15 minutos da aplicação destas drogas anestésicas, os animais tiveram a veia auricular canulada com cateter 24G. Os animais foram eutanasiados com overdose de tiopental sódico (100 mg/kg) por via intravenosa. Assim que foi constatada a completa parada cardíaca dos animais, foi realizada uma toracotomia nos animais, e o átrio direito dos mesmos foi aberto, e uma cânula foi introduzida em se ventrículo esquerdo. Solução salina a 0,9\% aquecida foi administrado diretamente no ventrículo esquerdo dos animais, até que o sangue fosse completamente retirado do sistema circulatório dos animais, o que foi confirmado através da visualização pela saída da solução salina através do átrio direito. Logo em seguida injetamos paraformaldeído a $4 \% \mathrm{com} \mathrm{pH}$ controlado na faixa de 7,5 a 8 pela mesma via anterior, em um total de $500 \mathrm{~mL}$ por animal. Logo em seguida com o auxílio de alvelótomo e goiva retiramos a medula espinhal dos animais, na porção lesionada experimentalmente, e fixamos em paraformaldeído a 4\% por 24 horas. Passadas às 24 horas iniciais no fixador em temperatura de geladeira, o material foi colocado em sucrose a $30 \%$ e mantido em geladeira por no máximo 3 dias até o processamento. A medula espinhal dos animais foi 
seccionada em 3 porções: cranial (1), lesão (2) e caudal. Os animais foram nomeados com letras, sendo portanto A, B, C (Figura 1).

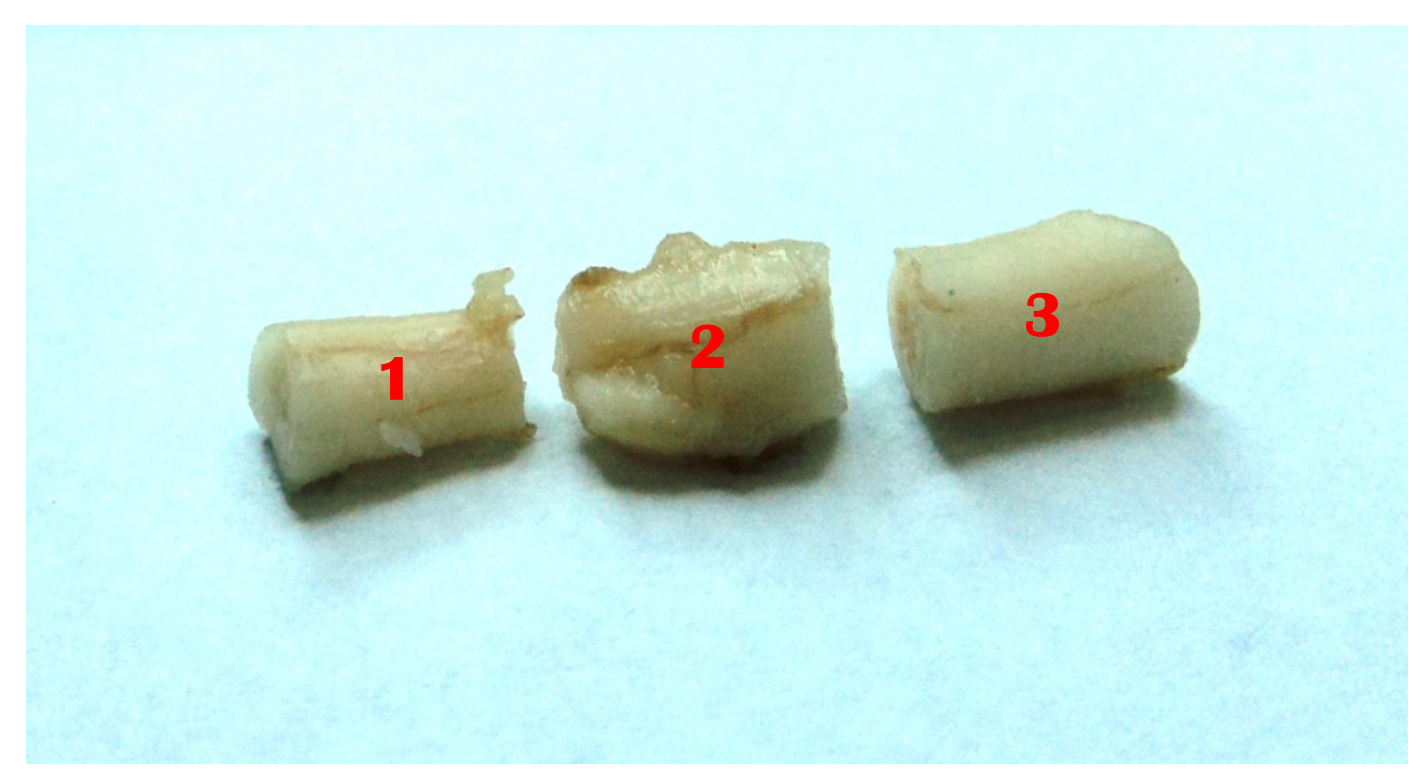

Figura 1 - Fotografia da Medula espinhal de coelho submetido à hemissecção dorsal seccionada em três porções: cranial a lesão (1), no foco da lesão medular (2), e caudal a lesão (3)

\subsection{Técnica de Coloração em Hematoxilina e Eosina}

Esta técnica de coloração foi realizada para avaliar a qualidade de fixação do material coletado. O tecido destinado à histologia foi fixado em paraformaldeído 4\%. Após o tempo mínimo de 24 horas o tecido foi processado e incluído em parafina. O processamento e inclusão foram feitos manualmente. Após o processamento e inclusão foram realizados cortes de $5 \mu \mathrm{m}$ de espessura obtidos das amostras emblocadas em parafina. As lâminas foram incubadas em estufa a $60^{\circ} \mathrm{C}$ por 2 horas para remoção do 
excesso de parafina dos cortes. Em seguida as lâminas foram imersas no xilol duas vezes, com duração de cinco minutos cada, desidratadas em séries decrescentes de alcoóis por 3 minutos em cada, imersas em Hematoxilina por cinco minutos, e depois lavadas em água corrente por dez minutos. As lâminas foram coradas em eosina por cinco minutos. Após isso, as lâminas foram passadas para o álcool $90 \%$ por cinco minutos também, e imersas duas vezes em álcool 100\%, com duração de cinco minutos cada imersão. Por fim, foram imersas duas vezes em xilol, com duração de cinco minutos cada imersão e montadas as lâminas com a fixação da lamínula para análise posterior em microscópio óptico.

\subsubsection{I dentificação da Proteína Verde Fluorescente (Green Fluorescent Profein - GFP) e da expressão de Glial Fibrilary Acid protein (GFAP) e de Sulfato de Condroitina Proteoglicano (SCPg) na Lesão Medular de Coelhos}

Os cortes incluídos em parafina foram corados primeiramente na rotina com Hematoxilina-Eosina (HE) para a observação dos cortes. Através das colorações por HE foi possível avaliar a qualidade da fixação, e assim, dar continuidade às coletas e procedimentos. A identificação da Proteína Verde Fluorescente (GFP) e da expressão de Glial Fibrilary Acid protein (GFAP) e sulfato de condroitina proteoglicano (SCPg) na medula espinhal de coelhos foi realizada utilizando os anticorpos anti-GFP (Living Colors GFP Monoclonal Antibody - Clontech, cat.\# 632375), anti-GFAP (Ac monoclonal de cam anti-GFAP clone 6F2, DBS) e Anti-Chondroitin 
Sulfate antibody [CS-56] (ab11570). As secções de 4-5 $\mu \mathrm{m}$ foram desparafinizados em xilol e reidratados em série decrescente de etanol. O desmascaramento antigênico foi realizado pelo aquecimento dos cortes em tampão citrato $(0,384 \mathrm{~g}$ de ácido cítrico monohidratado; $2,352 \mathrm{~g}$ de citrato de sódio tribásico diidratado; $1 \mathrm{~L}$ de água destilada, $\mathrm{pH}$ 6,0) por 15 minutos em forno de microondas. A atividade de peroxidase tecidual endógena foi bloqueada pela incubação em solução de peróxido de hidrogênio a 3\% em tampão Tris- $\mathrm{HCl}$ 1M, pH 7,5 (TBS, 60,57g de Tris para $500 \mathrm{~mL}$ de água ultrapura) por 30 minutos. Para o bloqueio de ligações inespecíficas, os cortes foram incubadas com soro de cabra a 10\% em TBS por 30 minutos. O anticorpo primário foi diluído a $1 \mu \mathrm{g} / \mu \mathrm{L}$ em tampão TBS contendo $1 \%$ de soro de cabra e incubado "overnight" a $4^{\circ} \mathrm{C}$ em câmara úmida. Paralelamente, cortes foram incubadas na mesma concentração com anticorpo irrelevante para o controle de isotipo (IgG). Após incubação com o anticorpo primário e todas as lavagens dos cortes foram realizadas com TBS contendo $1 \%$ de soro de cabra. A reação foi visualizada por meio do kit polivalente Dako-advance HRP Link (cat. \# K4069, Dako, EUA) de acordo com a recomendação do fabricante. A reação foi revelada por precipitação de 3,3'-diaminobenzidine (DAB Peroxidase Substrate Kit, 3,3'-diaminobenzidine, cat. \# SK-4100). Para finalizar os cortes foram contra-corados com hematoxilina, desidratados, diafanizados e as lâminas montadas para análise sob microscopia de luz. 


\subsection{CÃES}

\subsubsection{Delineamento experimental}

Os cães utilizados foram provenientes de diferentes clínicas veterinárias particulares de São Paulo, portadores de lesão medular crônica. Os animais apresentaram o quadro clínico a seguir:

- Paraplegia;

- ausência de propriocepção consciente;

- presença de reflexos ciáticos;

- patelares e tibial cranial exacerbados;

- ausência de sensibilidade dolorosa profunda com presença do reflexo podal ou de retirada nos membros pélvicos;

- diagnóstico de hérnia de disco toracolombar dos discos intervertebrais após radiografia simples, e ressonância magnética.

Foram considerados casos crônicos animais com perda da sensibilidade dolorosa profunda há mais de 7 dias.

Os proprietários que optaram por incluir seus animais na pesquisa, foram devidamente esclarecidos quanto ao procedimento, e após sanadas todas as dúvidas, os mesmos assinaram termo de compromisso em que 
afirmam estar de acordo com o procedimento e cientes de todos os riscos inerentes a cirurgia e ao transplante celular (Anexo A).

\subsubsection{Exames Complementares}

Todos os cães utilizados nesse experimento passaram por uma bateria de exames pré-operatórios, tais como hemograma completo, perfil renal e hepático, varredura abdominal através de ultrasonografia, e eletrocardiograma. Todos estes exames serão realizados para avaliar a real possibilidade de sobrevivência destes animais aos procedimentos diagnósticos e experimentais.

Quanto aos exames complementares de imagem, optamos pelo exame radiográfico comum, e a ressonância magnética. Esta última foi fruto de uma parceria com o Hospital Cães e Gatos de Osasco-SP. Os exames de ressonância magnética foram realizados nos momentos pré e pós-operatório, como forma de avaliação de uma possível regeneração medular. 


\subsubsection{Técnica Radiográfica Simples}

Para a realização das radiografias da coluna vertebral os cães foram posicionados em decúbito lateral direito para a obtenção de projeções latero-laterais. As projeções toracolombar ou lombossacra serão realizadas de acordo com a suspeita clínica do médico veterinário responsável pelo atendimento do animal, através de anamnese, exame físico e neurológico do animal.

A técnica radiográfica será adequada através da relação quilovoltagem, miliamperagem e espessura da área corporal a ser radiografada.

\subsubsection{Ressonância Magnética por I magem}

O mesmo protocolo anestésico descrito para a cirurgia descompressiva dos cães foi utilizado para a realização dos exames de ressonância magnética por imagem. Os pacientes foram posicionados em decúbito ventral sobre a mesa e foi realizado o estudo por ressonância magnética da coluna vertebral toracolombar e lombar, através de sequências sagitais e transversais a serem definidas no momento do exame pelo médico veterinário responsável pelo setor de imagem. 


\subsubsection{Técnica Anestésica e Cirúrgica para Descompressão da Medula Espinhal dos Cães e Transplante das Células-Tronco da Polpa Dentária Humana I matura}

Inicialmente os animais receberam como pré-medicação anestésica 0,05 mg/ $\mathrm{Kg}$ de acepromazina associada a $4 \mathrm{mg} / \mathrm{Kg}$ de cloridrato de meperidina por via intramuscular (IM) e após 15 minutos serão induzidos à anestesia geral inalatória com $5 \mathrm{mg} / \mathrm{Kg}$ de propofol por via intavenosa (IV), sendo mantidos com Isofluorano diluído em O2 a 100\%. Durante procedimento cirúrgico os animais sofreram hemilaminectomia dorsolateral no local da lesão medular. A incisão foi realizada lateralmente à linha média dorsal à lesão, a qual foi previamente identificada com auxílio da ressonância magnética. Após incisão completa da pele e músculos, foi incisada a fáscia lombodorsal ao lado dos processos espinhosos e com auxílio de um elevador de periósteo foram isolados os processos espinhosos desejados. Ao expor a superfície dorsal do processo articular, realizou-se uma janela para acesso ao canal vertebral. Primeiramente foi identificada a massa medular comprimida, e removido logo em seguida, o conteúdo extrusado. Procedeu-se a injeção das células da polpa dentária imatura intramedular em três pontos distintos: $1 \mathrm{~mm}$ proximal a lesão, diretamente sobre o foco da lesão e $1 \mathrm{~mm}$ distal a lesão. O processo pós-operatório consistiu na terapia com o antibiótico (cefazolina 30mg/Kg/BID) por 10 dias, antiinflamatório (meloxicam 
$0,1 \mathrm{mg} / \mathrm{Kg} / \mathrm{SID}$ ) por 3 dias e analgésicos (cloridrato de tramadol $2 \mathrm{mg} / \mathrm{Kg} / \mathrm{TID}$ associado a $25 \mathrm{mg} / \mathrm{Kg} / \mathrm{TID}$ ) durante 5 dias.

\subsubsection{Avaliação Comportamental}

Um teste comportamental foi utilizado para avaliar a recuperação funcional dos membros posteriores (Anexo B). Cada cão foi filmado por 10 minutos por um mínimo de 10 passos de cada lado, e por trás ao caminhar em piso comum. Os cães foram auxiliados com a utilização de um pano passado através da pelve para suportar seus membros posteriores. Utilizando uma escala analógica de 14 pontos (Escala de Olby), a marcha dos cães foi pontuada por dois expectadores avessos ao experimento através das filmagens individuais de cada animal. Uma pontuação foi obtida após $0,7,30$ dias após o transplante das células tronco (OLBY et al., 2001). 


\section{RESULTADOS}

Os resultados serão apresentados de acordo com a espécie animal trabalhada.

\subsection{COELHOS}

Seguem os resultados referentes ao experimento de rastreamento das células em coelhos.

\subsubsection{I ndução da Lesão Medular por Hemissecção em Coelhos}

O coelho (Oryctolagus cuniculus) da linhagem Nova Zelândia demonstrou ser um modelo animal bastante acessível, dócil, exigindo mínimo espaço físico e pouca despesa para sua manutenção. 
Foram realizados dois tipos de hemissecção medular na altura da vértebra torácica T11, em 6 coelhos experimentais: hemissecção medular dorsal (HD) e ventral (HV),

O acesso cirúrgico para realização da técnica de HD foi o mesmo descrito anteriormente em nosso material e métodos (Figura 2). 


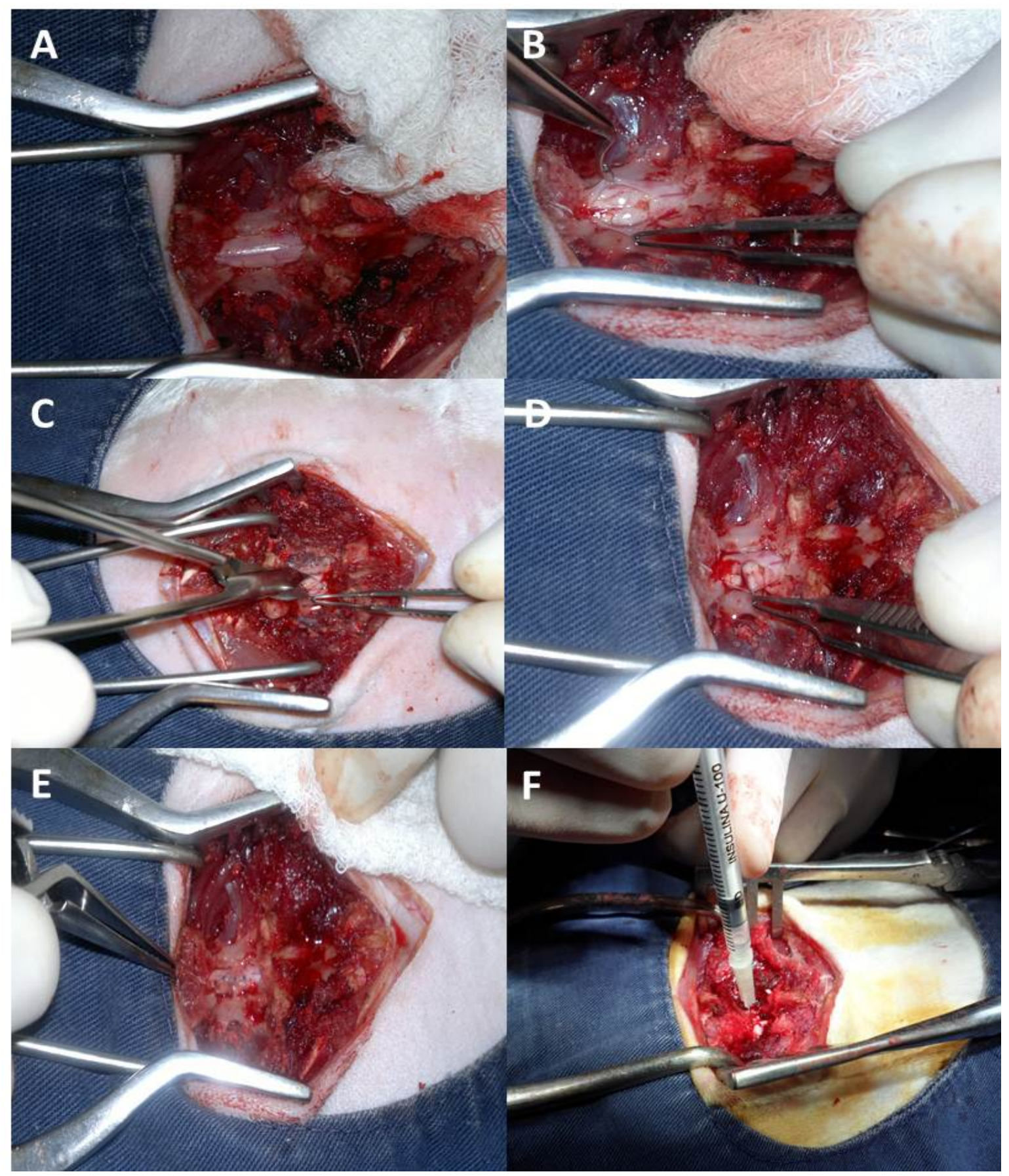

Figura 2 - Fotografias de Hemisecção dorsal em coelhos. A - Exposição da medula espinhal após laminectomia dorsal. B - Durotomia. C - Hemisecção dorsal com tesoura de íris. D - Exposição da medula após hemisecção dorsal. E - Sutura da dura máter com pontos simples separados de fio prolipropileno 7-0. F - Injeção das células-tronco do epitélio olfatório de coelhos no foco da lesão medular. 
Para realização da técnica de HV, um fio de cerclagem de aço foi passado por baixo da medula espinhal, sendo utilizado para passar o fio de polipropileno por baixo da medula espinhal. Logo em seguida a medula foi trespassada pelo fio de prolipropileno 7-0, sendo a medula seccionada na sua porção ventral com o fechamento do nó cirúrgico (Figura 3).

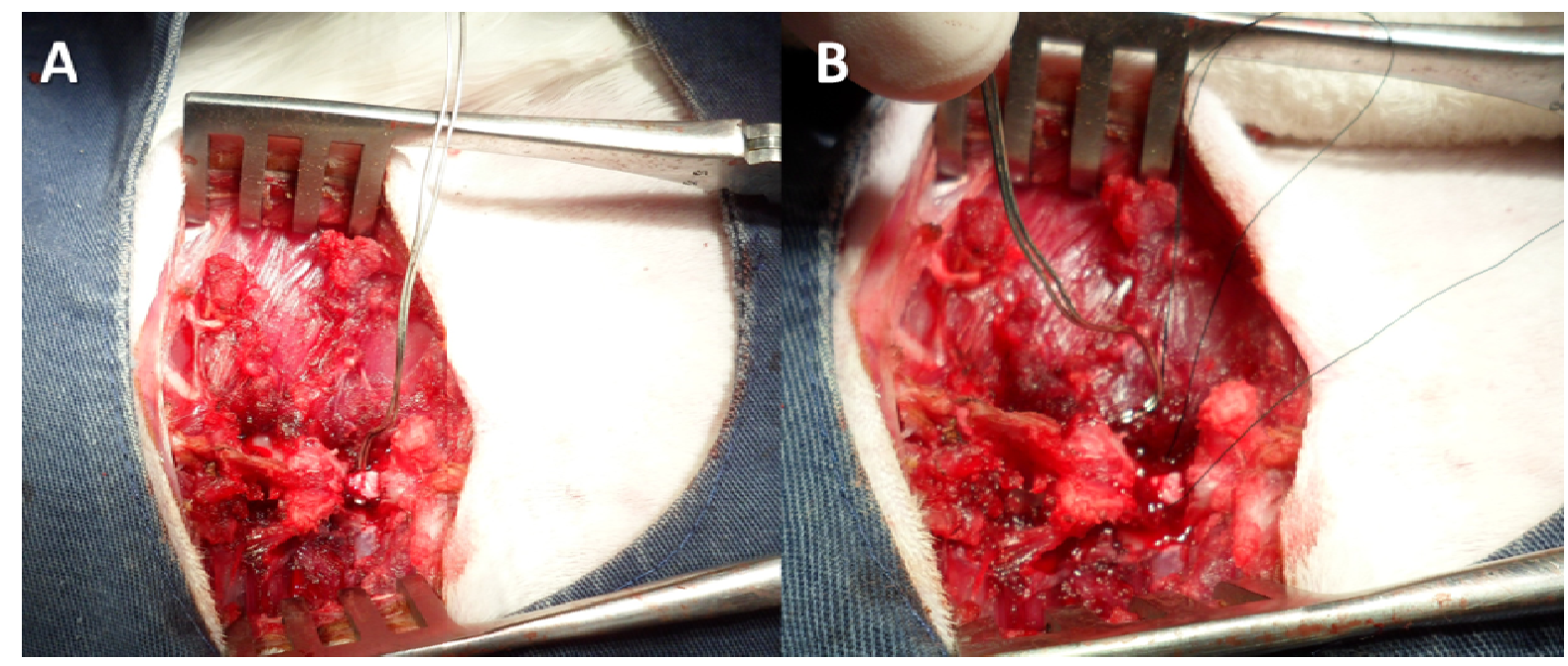

Figura 3 - Fotografia da técnica cirúrgica de hemissecção medular ventral em coelho. A - Passagem do fio de cerclagem de aço por baixo da medula espinhal. B - Passagem do fio de prolipropileno 7-0 por baixo da medula espinhal.

Os animais submetidos às hemissecções passaram por avaliação neurológica quanto a sua sensibilidade a dor profunda, superficial e reflexos posturais. Esses animais passaram por filmagens seriadas a fim de avaliar o grau de evolução de acordo com a escala comportamental de Basso et al. (1995), também conhecido como teste BBB (Basso, Beattie and Bresnahan), que varia de 0 até 21 , adaptado de ratos para esse estudo em coelhos (Figura 4). 


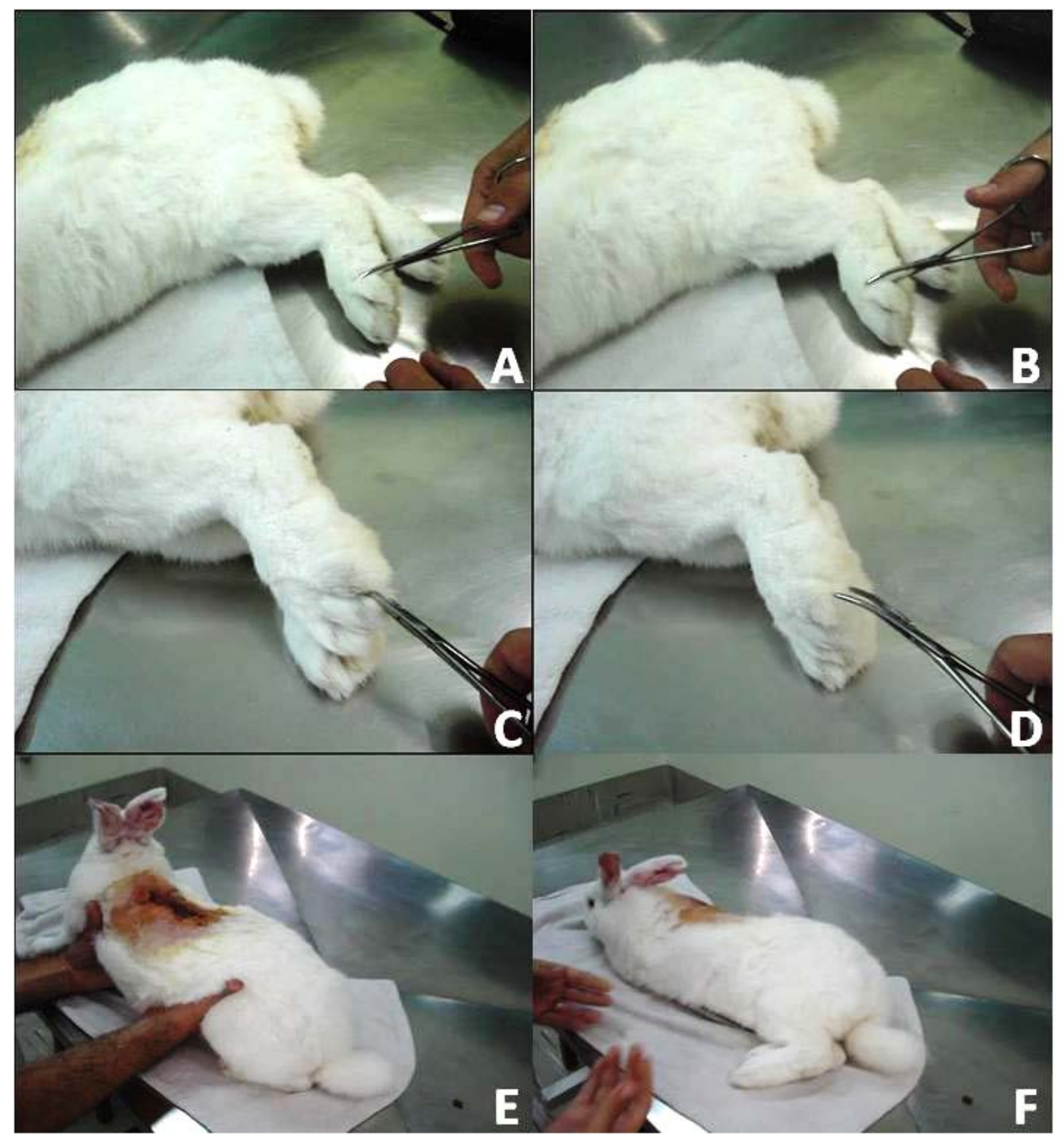

Figura 4 - Fotografias da avaliação neurológica dos coelhos após a indução da lesão medular por hemissecção. A,B - Avaliação da sensação de dor profunda após pinçamento de dígito. C,D - Avaliação da sensação de dor superficial após pinçamento de interdígitos. E,F - Avaliação da manutenção postural. 
Os animais submetidos à HD já no pós-operatório imediato demostravam os RDS e RDP, ausência dos reflexos de micção espontânea, e de defecação, e presença dos reflexos de retirada dos membros. Após 12-15 dias do pós-operatório os animais já buscavam a posição ventro dorsal, quadrupedal, muito embora com movimentos reduzidos, estes animais já conseguiam movimentar os membros pélvicos. Após 1 mês de realização da cirurgia, alguns animais já deambulavam, com reflexo postural mantido e davam passos, adquirindo uma média de 16 pontos na escala de BBB. Os animais utilizados neste experimento permaneceram vivos até o final do mesmo sem muitas complicações pós-operatórias. No Anexo C (FEITOSA, 2010 $)$ podemos observar o coelho submetido à técnica de hemissecção dorsal medular após 30 dias de realização da cirurgia deambulando. Movimento das articulações, apoio plantar e capacidade de suportar o próprio peso foram observados. O reflexo postural foi mantido nestes animais. Algum déficit locomotor foi observado em alguns dos passos dos animais submetidos a essa técnica, motivo pelo qual estes animais não obtiveram pontuação máxima nos testes realizados.

Os animais submetidos à HV perderam completamente os reflexos posturais, e a sensação de dor profunda, e superficial, não retornando após 15 dias de observação. Esses animais mantiveram os reflexos de micção espontânea e defecação, muito embora apresentassem disquezia. Após 30 dias de avaliação através do teste comportamental de Basso et al. (1995), foi constada uma pontuação média de 1 ponto (Anexo D) 
$($ FEITOSA, 2010 $)$. Após esse período os animais apresentavam reflexo de retirada dos membros, porém, com ausência de dor profunda e superficial (Anexo E e F) (FEITOSA, 2010 ${ }^{c, d}$ ).

Nas filmagens referentes aos anexos $E$ e $F$, pode-se observar que apesar de o animal retirar os membros após o estímulo doloroso, o mesmo não olha para o mesmo, nem demonstra intenção de fugir, o que caracteriza o reflexo de retirada preservado, muito embora sem presença de dor.

Os três animais submetidos à $\mathrm{HD}$ e os outros três animais submetidos à HV, foram avaliados aos 5, 15 e 30 dias de pós-operatório, obtendo uma média de pontuação que foi comparada diretamente no gráfico a seguir (Gráfico 1). 


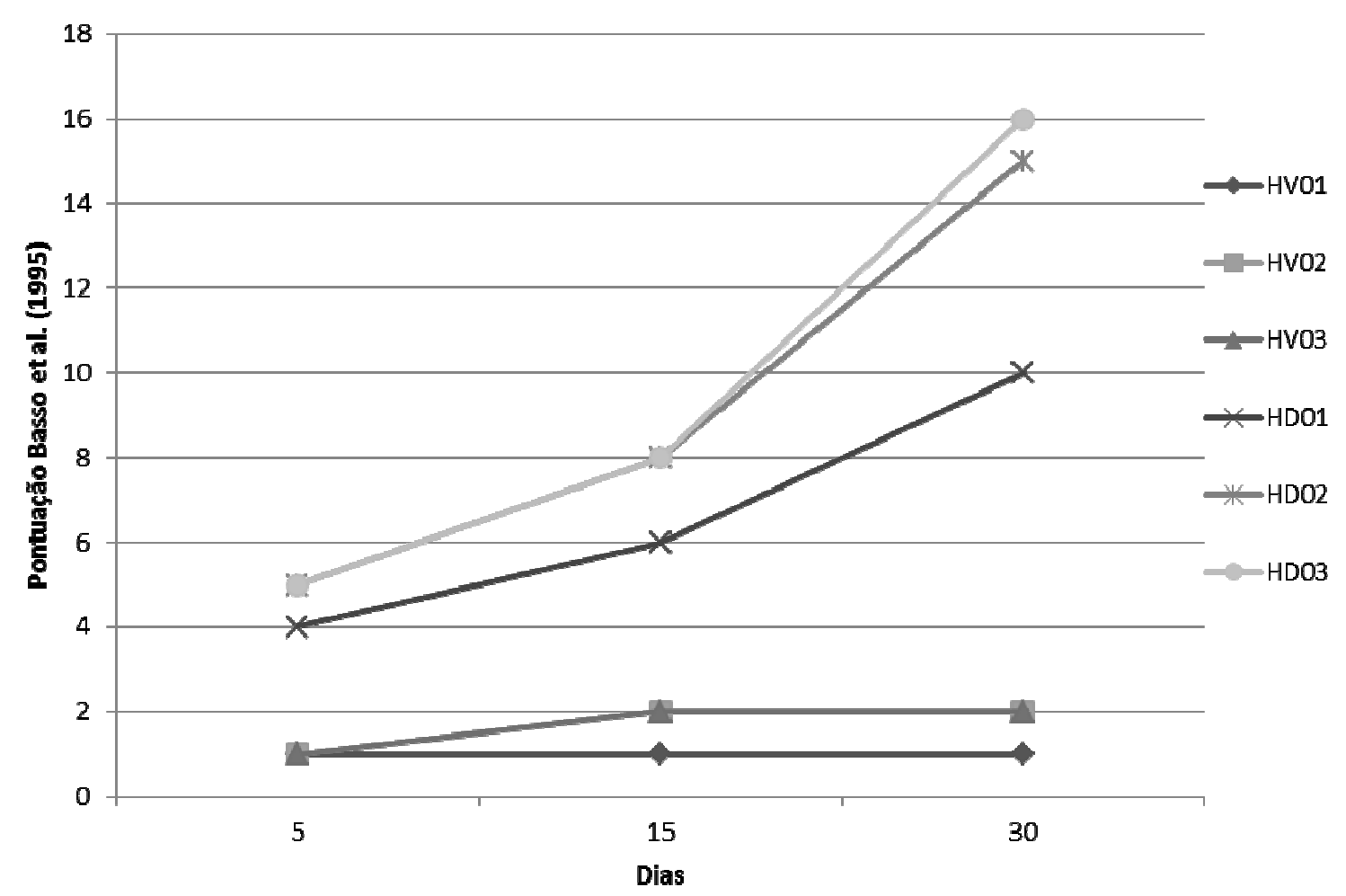

Gráfico 1 - Avaliação através do teste de Basso et al. (1995) obtidas pelos coelhos submetidos à hemissecção dorsal e ventral, por 30 dias.

Dos 5 animais utilizados para realização da técnica de hemisecção ventral, três sobreviveram até o tempo de eutanásia, sendo que os demais vieram a óbito em decorrência de infecções secundárias, tais como cistite, pneumonia e sepse generalizada. Os três animais que sobreviveram até o final deste experimento apresentaram quadros de cistite e pneumonia, que foram controlados através de antibioticoterapia. Outras complicações pós-operatórias relacionadas a utilização da técnica de HV foram anorexia, cistite, disquezia e timpanismo. Todos esses aspectos foram levados em conta, para descartar esse modelo para a realização dessa pesquisa, optando então pelo modelo de hemissecção dorsal. 


\subsubsection{Terapia Celular com Células-Tronco do Epitélio Olfatório de Coelhos}

As células-tronco do epitélio olfatório de coelhos foram transduzidas de acordo com protocolo descrito em nosso material e métodos (Figura 5).

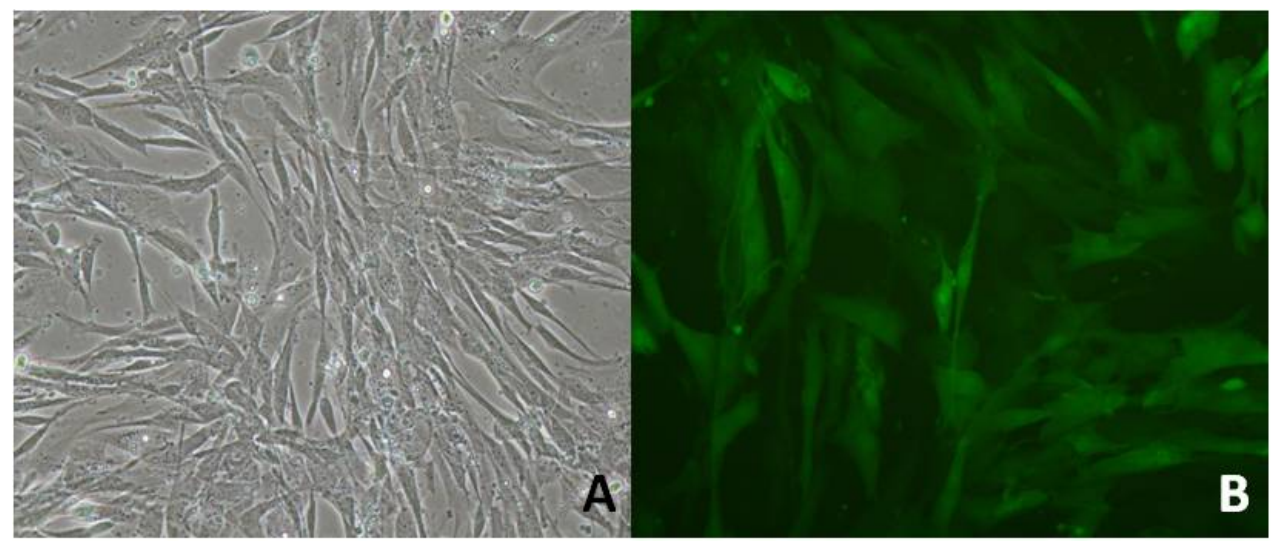

Figura 5 - Fotomicrografias de células-tronco do epitélio olfatório de coelhos. A - Células-tronco do epitélio olfatório de coelho. Células-tronco do epitélio olfatório do coelho transduzidas com o gene repórter GFP evidenciados pela exposição à luz UV. Aumento de 200x

Uma população de células GFP em cultivo foram selecionadas através de citometria de fluxo (Cell sorting), obtendo dessa forma um cultivo uniforme de células tronco do epitélio olfatório de coelhos transduzidas com o gene repórter em questão (Figura 6). 

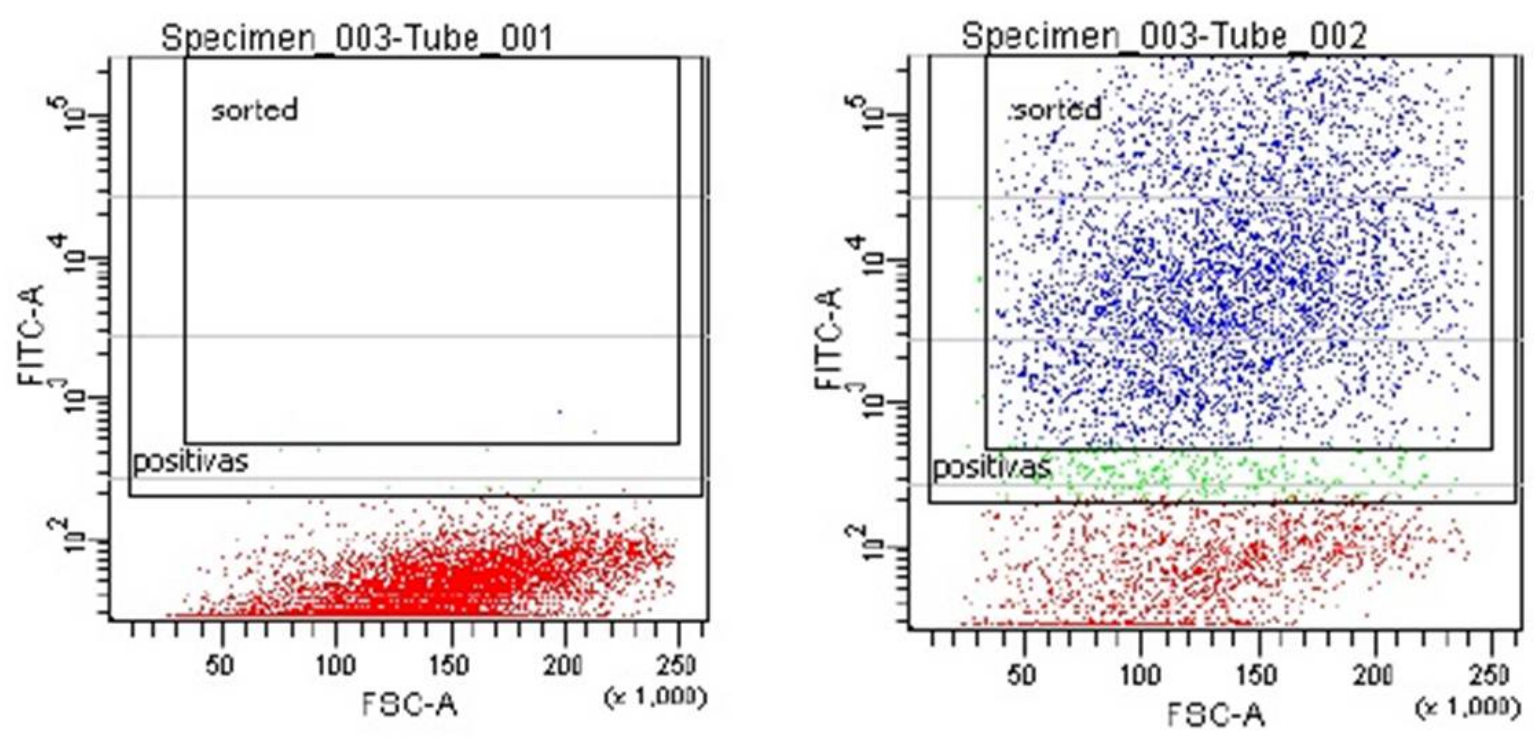

Figura 6 - Cell sorting das células tronco do epitélio olfatório de coelhos, na esquerda uma população de células não transduzidas com o gene, e na direita uma população de células tronco do epitélio olfatório de coelhos eficientemente tranzduzidas com o gene repórter GFP

Três animais foram injetados com células tronco do epitélio olfatório de coelhos carreando o gene repórter GFP e três coelhos foram injetados com PBS para comparação posterior.

\subsubsection{Avaliação histológica e imunohistoquímica dos coelhos submetidos à hemissecção medular}

Os animais foram eutanasiados de acordo com o protocolo já descrito no material e métodos, aos 30 dias de experimento. O animal $\mathrm{B}$ veio a óbito durante a realização da técnica cirúrgica em decorrência de 
parada cardíaca fulminante. Macroscopicamente a medula espinhal do animal C pareceu mais alterada, com necrose focal no local da lesão medular realizada, quando comparada ao animal A (Figura 7). Uma gliose evidente está presente na medula espinhal coletado do animal A (Figura 7-A).

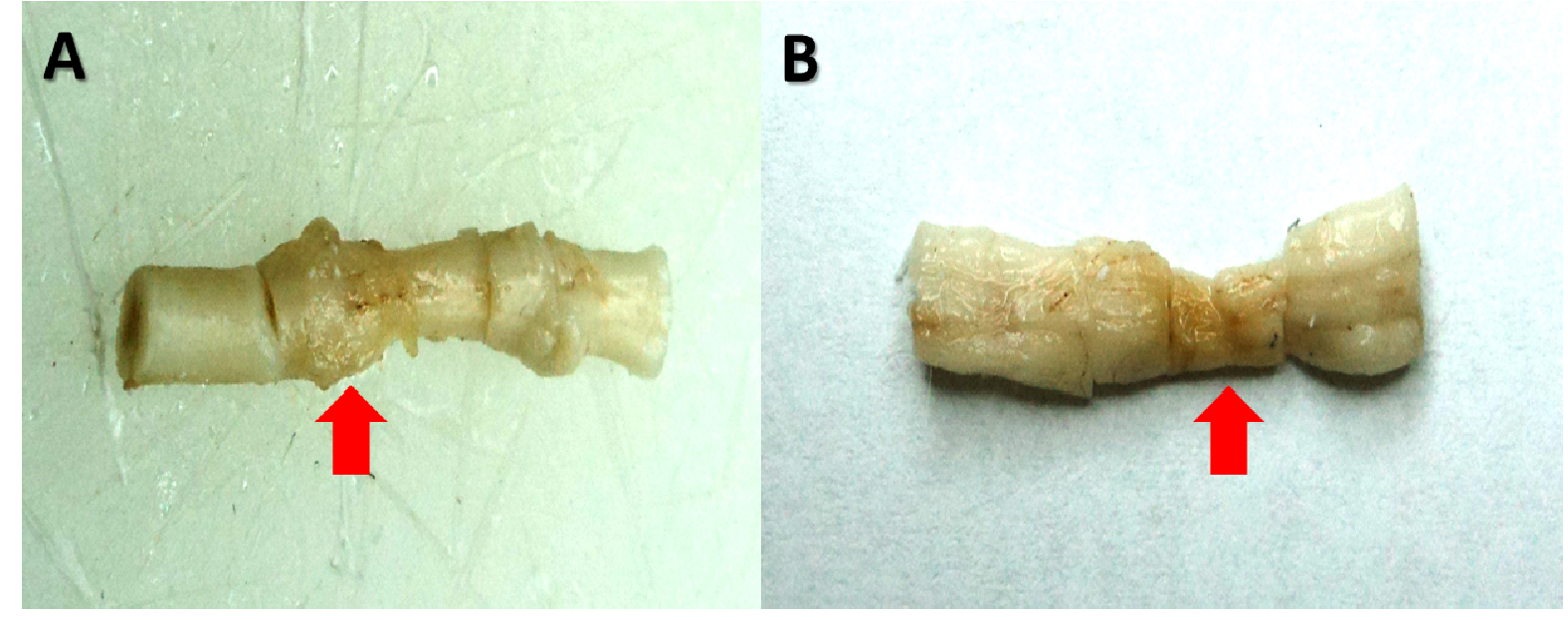

Figura 7 - Fotogradias das medulas coletadas de animais submetidos a terapia celular com células tronco do epitéio olfatório de coelhos. A - Seta vermelha aponta região de extensa reação astrocítica, evidenciada pela gliose evidente no foco da lesão criada. B - Seta vermelha apresenta região necrótica da medula espinhal de coelho

Foi realizada a coloração de HE nos cortes de medula dos dois animais experimentais (Figura 8). As porções imediatamente anteriores a lesão medular apresentavam algumas alterações histológicas evidenciadas nas porções 1 e 2 nos dois animais experimentais. As principais alterações notadas foram vacuolização neuronal, ausência de neurônios corados e intensa degeneração neuronal. As porções posteriores (3) à lesão medular não apresentaram alterações evidentes. Outros achados relevantes foram: edema, necrose, infiltrado celular e 
cavitação. A lesão criada na porção dorsal pareceu afetar a região anterior à lesão, causando as alterações patológicas descritas anteriormente, e evidenciadas na figura 8-B, apontada pela estrela. A região da lesão aparentou extensa desorganização demonstrada nas figuras 8-C, 8-D e 8-E, com região mais alterada apontada pela cruz. Não se nota a presença da porção dorsal do $\mathrm{H}$ medular nas regiões anterior e de lesão, o que evidencia o local exato onde foi realizada a hemissecção dorsal medular. 


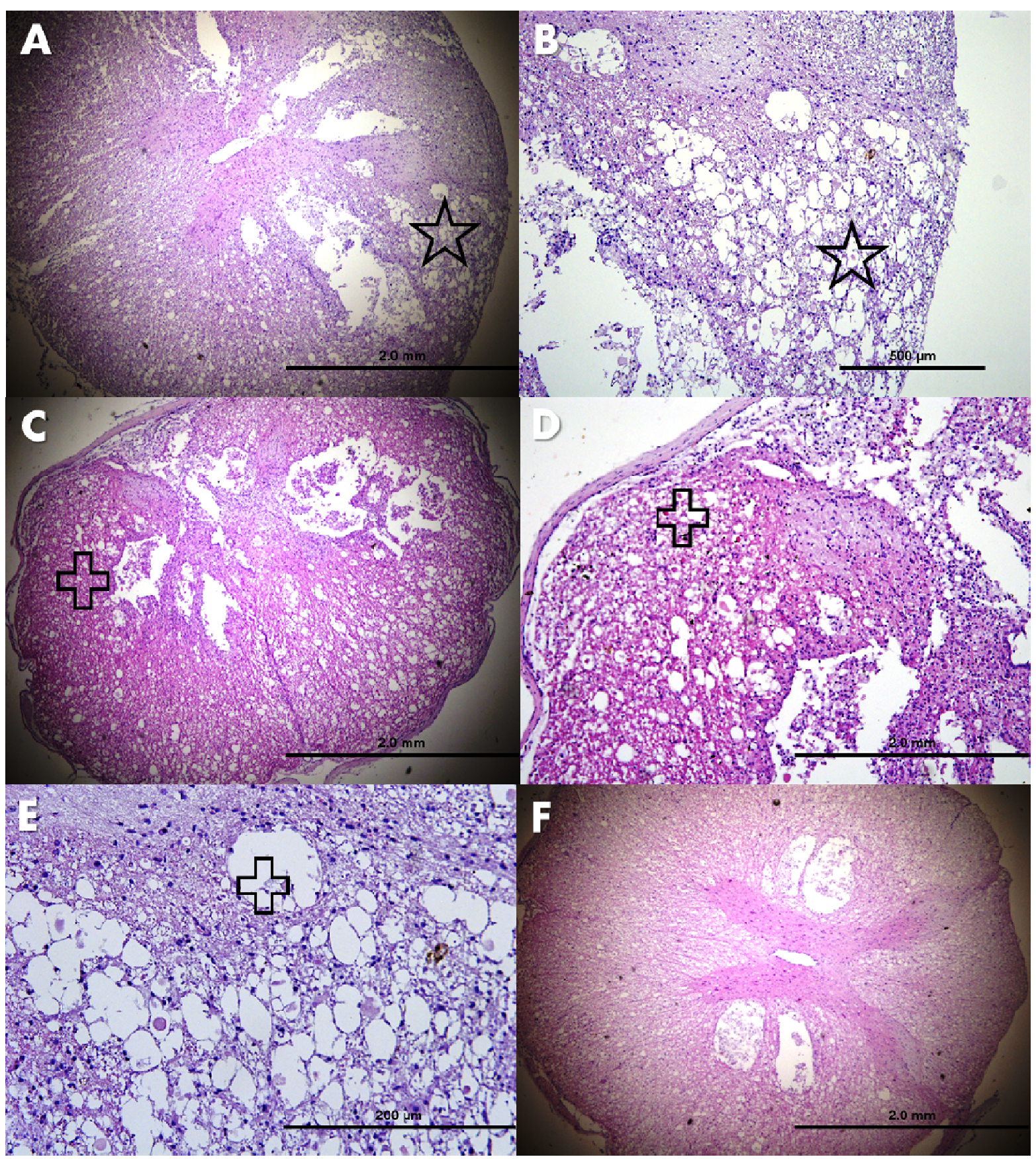

Figura 8 - Fotomicrografias em coloração de HE de porções da medula espinhal de coelho submetido à hemissecção dorsal da medula espinhal e injeção de células-tronco do epitélio olfatório de coelhos. A - Porção medular anterior à lesão causada, estrela evidencia área de vacuolização neuronal, aumento de 4x. B - Mesma região em aumento de 10x. C - Região da medula espinhal onde foi realizada a hemissecção medular dorsal, cruz aponta região de desorganização celular e áreas de vacuolização neuronal. D - Mesma região da medula demonstrada em C com aumento de 10x. E - Mesma porção da medula espinhal demonstrada em C com aumento de 20X. F - Porção da medula espinhal posterior à lesão medular causada 
Foi realizada coloração de HE em dois dos animais controles, pois um dos animais veio a óbito posteriormente (Figura 9). Foram realizados cortes longitudinais desse material, a fim de identificar a lesão como um todo. A área lesionada foi delimitada em vermelho nas figuras 9-A e 9-B. Rarefação celular foi notada nesses cortes histológicos, além de desorganização e extensas áreas de vacuolização neuronal.

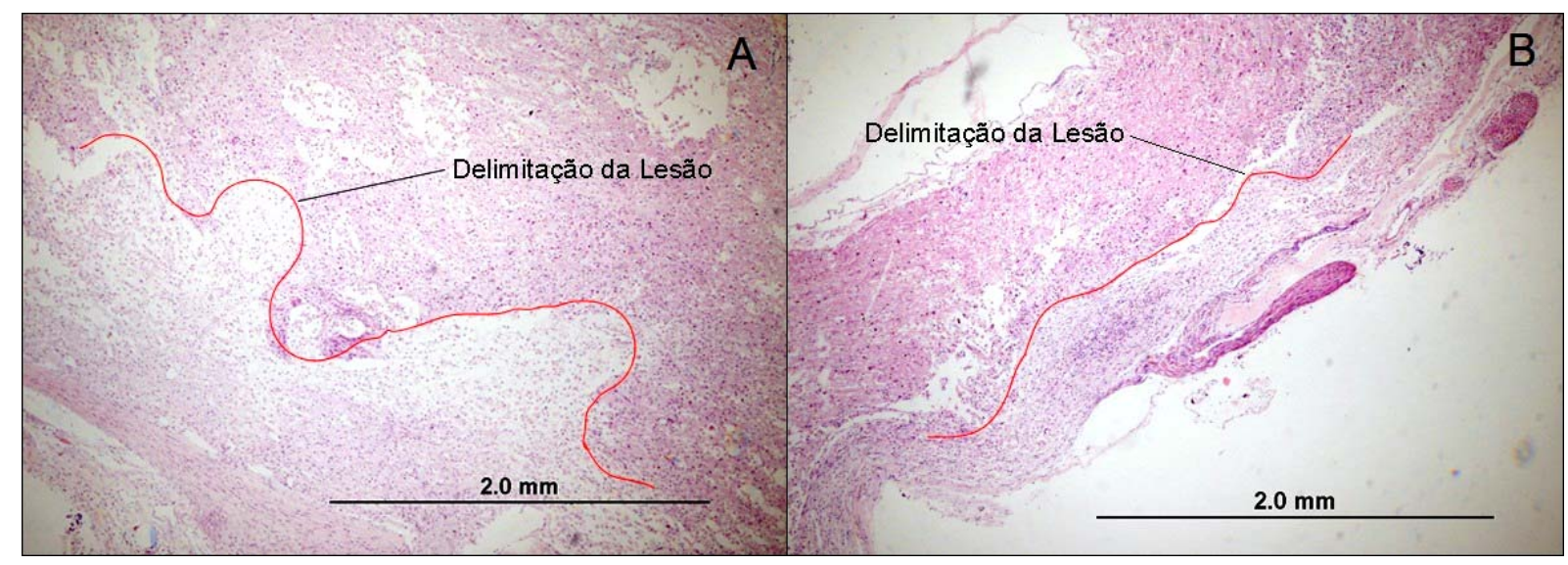

Figura 9 - Fotomicrografias de coloração de hematoxilina e eosina em medula espinhal de coelhos submetidos à hemissecção dorsal da medula espinhal. A - Área de extensa rarefação celular da medula em sua porção dorsal. B - Infiltrado celular evidenciado pela estrela.

Alternativamente a utilização de anticorpos para detecção da cicatriz glial, realizamos um estudo em paralelo para utilização da coloração de alcian blue na detecção da cicatriz da glia, obtendo sucesso na padronização da técnica (Figura 10). Podemos observar a clara deposição de sulfato de condroitina realizada pelos astrócitos no processo de formação da cicatriz glial (Figura 10A). Observa-se o corante marcando 
a dura máter, devido à característica glicoproteica da mesma (Figura 10B). Em 10-C além do extenso infiltrado inflamatório observa-se a deposição de sulfato de condroitina. Por fim, em 10-D observa-se a lesão delimitada e a gliose formada em decorrência da lesão medular criada.

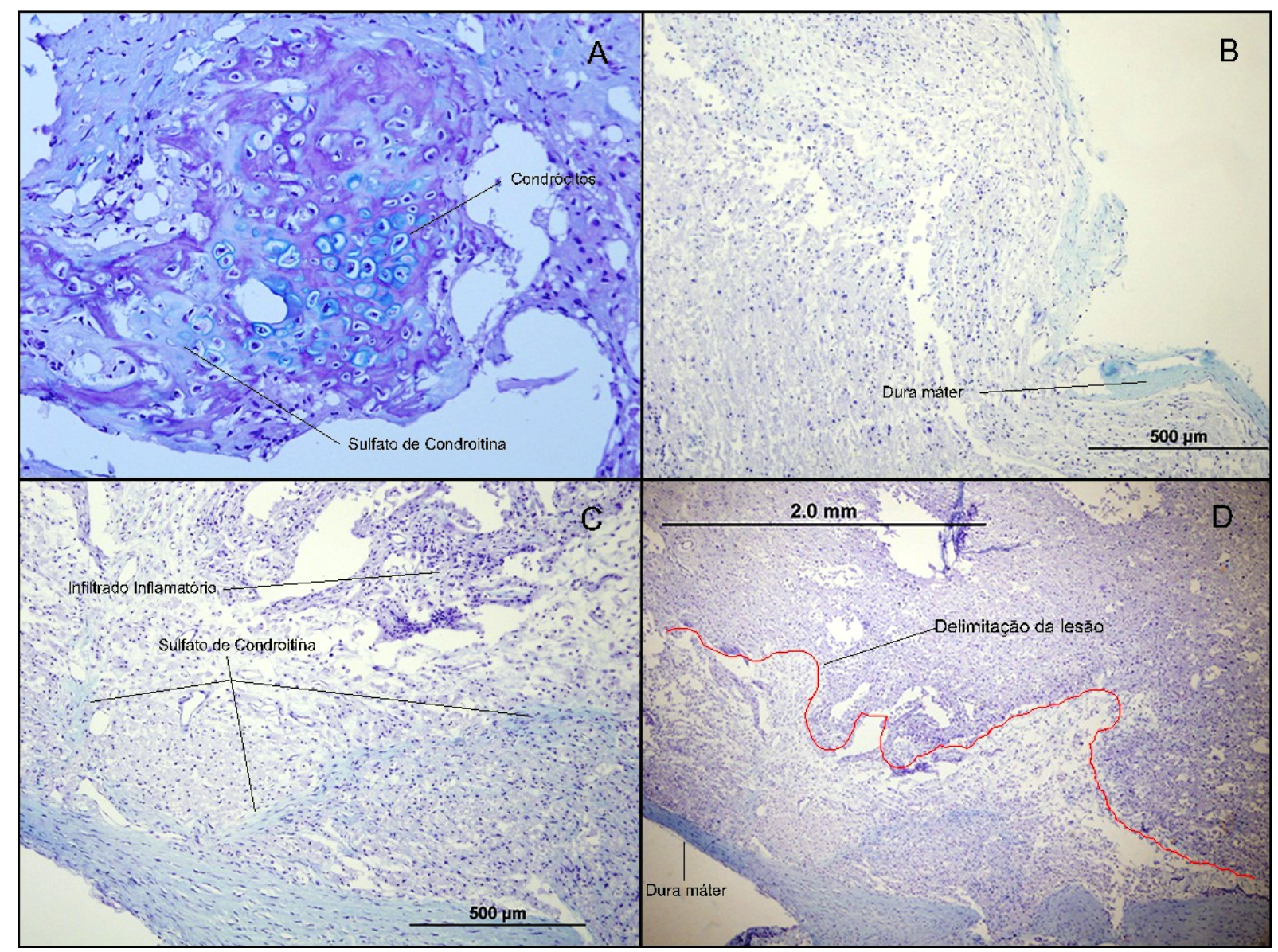

Figura 10 - Fotomicrografias de coloração de azul de alcian da medula espinhal de coelhos submetidos à hemissecção medular dorsal. A - Sulfato de condroitina corado pelo azul de alcian. B - Dura máter corada pelo azul de alcian. C - Infiltrado inflamatório e sulfato de condroitina corados pelo azul de alcian. D - Hemissecção medular dorsal delimitada 
A expressão do anticorpo anti-sulfato de condroitina foi positiva, evidenciando marcação no tecido medular em sua porção lesionada (Figura 11).

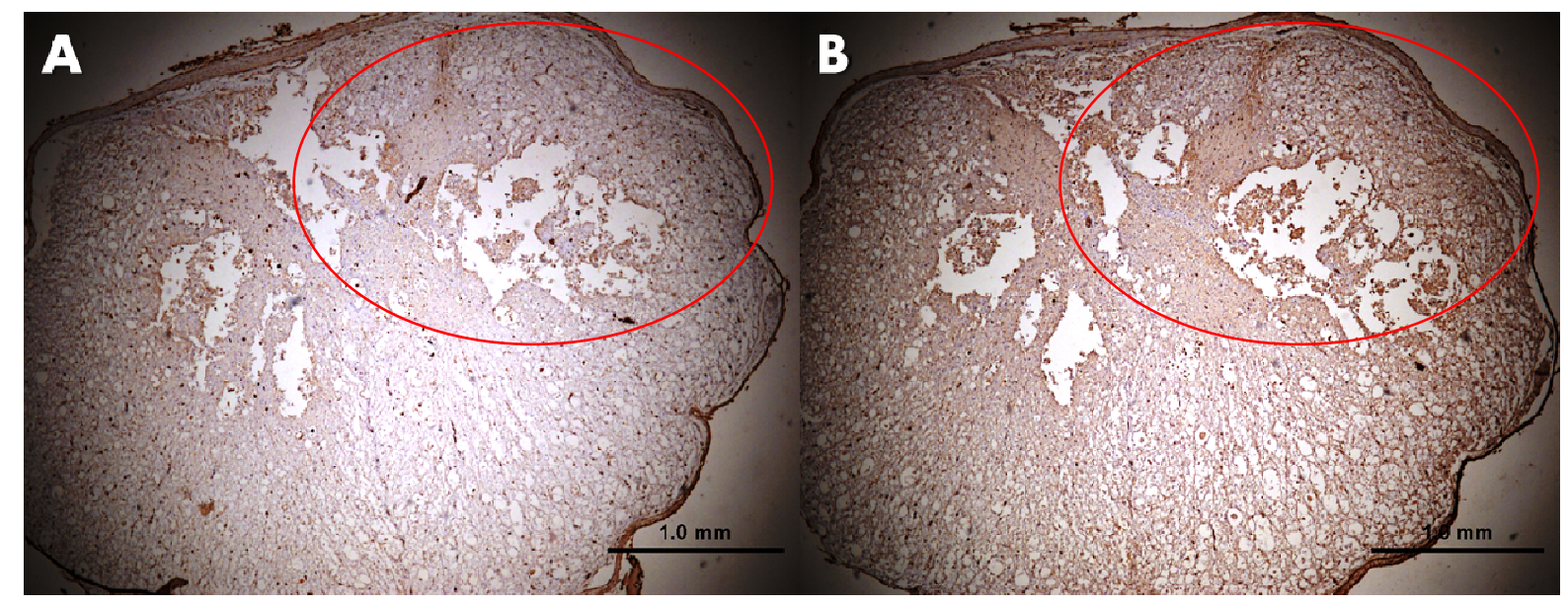

Figura 11 - Fotomicrografias da expressão do anticorpo anti-sulfato de condroitina na lesão medular espinhal por hemissecção dorsal em coelhos. A - Controle negativo sem anticorpo primário. B - Expressão de sulfato de condroitina proteoglicano na lesão medular espinhal de coelhos causada por hemissecção dorsal. Círculos vermelhos apontam a marcação obtida

A expressão do anticorpo anti-proteína fluorescente verde (Green

Fluorescent Protein - GFP) também foi positiva no tecido lesionado, comprovando a presença das células do epitélio olfatório injetadas no foco da lesão medular (Figura 12). 


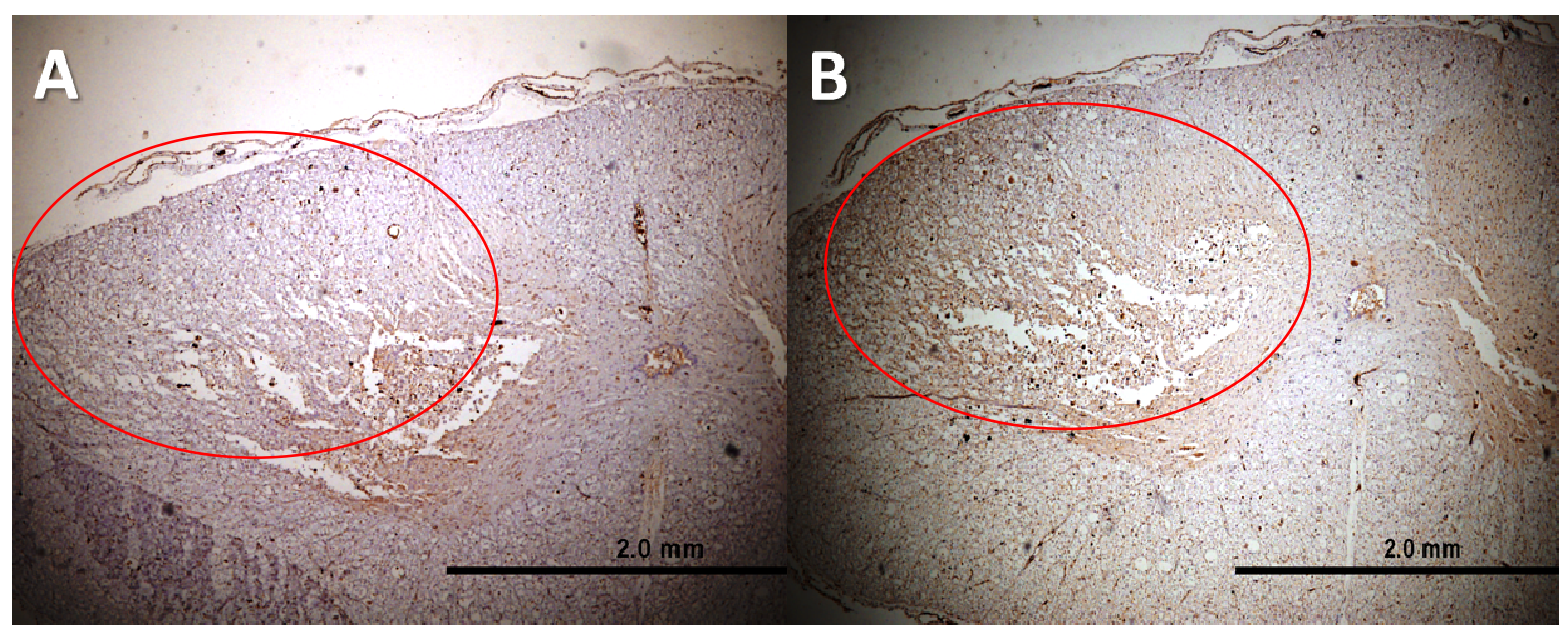

Figura 12 - Expressão do anticorpo anti-GFP em porção de medula espinhal de coelhos submetidos à hemissecção medular dorsal da medula espinhal. A - Controle negativo sem anticorpo primário. B - Ensaio positivo com anticorpo primário demonstrando a expressão do anticorpo anti GFP na porção dorsal da medula espinhal. Círculos vermelhos apontam o local da marcação

Até a data de depósito da tese, a técnica de imunohistoquímica para detecção do anticorpo anti-GFAP ainda encontrava-se em adaptação de protocolo. Porém os dados serão utilizados na confecção do artigo cientifico a ser submetido a Revista Internacional. 
5.2 CÃES

\subsubsection{Animais}

Foram submetidos ao transplante de células-tronco três animais machos com idades e raças diferentes, portadores de lesão medular crônica, decorrente de extrusão e luxação de discos intervertebrais comprimindo a medula espinhal (Tabela 1 ).

Tabela 1. Casos clínicos selecionados

\begin{tabular}{ccccc}
\hline Animal & I dade & Raça & Causa (s) & $\begin{array}{c}\text { Espaços } \\
\text { intervertebrais }\end{array}$ \\
\hline Juquinha & 6 anos & Lhasa apso & Extrusão de disco & T12-T13 \\
Billy & 9 anos & Teckel & Extrusão e luxação & T13-L1 \\
Luigi & 9 anos & Yorkshire & Extrusão de disco & T10 à L2 \\
\hline
\end{tabular}

\subsubsection{Exames complementares pré-operatórios}

Todos os animais utilizados apresentaram valores bioquímicos séricos (Tabela 2), hematimétricos (Tabela 3) e leucométricos (Tabela 4) 
dentro dos parâmetros de normalidade. Adicionalmente, os exames de eletrocardiograma e ecocardiograma não apresentaram alterações dignas de nota. A obtenção desses exames foi o primeiro passo para a continuidade do estudo, uma vez que nos forneceu dados que nos possibilitaram encaminhar o animal para o exame de ressonância magnética onde o mesmo foi anestesiado. A realização de um protocolo anestésico sem a realização dos exames pré-operatórios potencializaria o já existente risco anestésico.

Tabela 2 - Bioquímica sérica dos animais experimentais.

\begin{tabular}{ccccc}
\hline Animal & $\begin{array}{c}\text { Uréia } \\
\mathbf{m g} / \mathbf{d l}\end{array}$ & $\begin{array}{c}\text { Creatinina } \\
\mathbf{m g / \mathbf { d l }}\end{array}$ & Fosfatase Alcalina UI/ L & $\begin{array}{c}\text { ALT(TGP) } \\
\text { UI / L }\end{array}$ \\
\hline Valores de Referência & 10 a 60 & 0,5 a 1,6 & 10 a 96 & 7 a 92 \\
J uquinha & 29,0 & 1,0 & 75,0 & 35,0 \\
Billy & 18,0 & 0,8 & 85,0 & 40,0 \\
Luigi & 15,0 & 1,4 & 16,0 & 28,0 \\
\hline
\end{tabular}

Tabela 3 - Eritrograma dos animais experimentais.

\begin{tabular}{ccccc}
\hline Animal & $\begin{array}{c}\text { Eritrócitos } \\
\text { milhões/ } \mathbf{m m}^{\mathbf{3}}\end{array}$ & $\begin{array}{c}\text { Hemoglobina } \\
\mathbf{g \%}\end{array}$ & $\begin{array}{c}\text { Hematócrito } \\
\mathbf{g \%}\end{array}$ & $\begin{array}{c}\text { Proteínas } \\
\text { Totais } \\
\mathbf{g} \%\end{array}$ \\
\hline $\begin{array}{c}\text { Valores de } \\
\text { Referência }\end{array}$ & 4 a 7 & 14 a 19 & 45 a 56 & 6 a 8 \\
Juquinha & 6,0 & 10,5 & 50 & 7 \\
Billy & 5,0 & 15,6 & 55 & 7,5 \\
Luigi & 5,8 & 17 & 53 & 6,8 \\
\hline
\end{tabular}


Tabela 4 - Leucograma dos animais experimentais.

\begin{tabular}{ccccc}
\hline Animal & $\begin{array}{c}\text { Leucócitos } \\
\%\end{array}$ & $\begin{array}{c}\text { Segmentados } \\
\%\end{array}$ & $\begin{array}{c}\text { Bastonetes } \\
\%\end{array}$ & $\begin{array}{c}\text { Eosinófilos } \\
\%\end{array}$ \\
\hline $\begin{array}{c}\text { Valores de Referência } \\
\text { Juquinha }\end{array}$ & 8,000 a 16,000 & 55 a 80 & 0 a 1 & 1 a 9 \\
Billy & 8200 & 76 & 0 & 2 \\
Luigi & 9000 & 80 & 1 & 7 \\
\hline
\end{tabular}

\subsubsection{Transplante de Células Tronco da Polpa Dentária Humana I matura em Cães com Lesão Medular Crônica}

Nossos resultados serão apresentados na forma de casos clínicos individuais a seguir:

\section{CASO CLÍ NI CO 1}

Animal com 6 anos de idade, da raça Ihasa apso, do sexo masculino com lesão medular crônica há mais de 2 anos. Realizando ozonioterapia e fisioterapia há mais de dois anos sem sucesso.

Foi realizado estudo da coluna vertebral toracolombar através de ressonância magnética. Foram realizadas sequências sagitais e 
transversais ponderadas em T2, transversal em "3DHyce" e dorsal em STIR.

O exame permitiu visualizar diminuição do sinal multifocal dos discos intervertebrais, em diferentes graus, ao longo da coluna torácica e lombar, sendo mais evidente em T10-11 e T12-13. Na altura do espaço intervertebral de T12-13, foi encontrada estrutura hipotensa em posição ventral e a direita, causando moderada compressão da medula espinhal, na altura do forame intervertebral. Leve dilatação fluida do canal da medula espinhal foi vista cranial a esta lesão. Esta não se estende mais cranial que o corpo vertebral de T12. De forma multifocal, discretas protusões do ânulo fibroso dos discos intervertebrais, ventrais a medula espinhal foram vistos em L1-2 e L6-7, com leve perda do sinal epidural ventral em L1-2 e sem perda do sinal epidural ou compressão de raízes nervosas em L6-7. Nesta última, a discreta protusão é localizada ligeiramente mais para o lado direito. Estrutura arredondada, alongada e hipotensa, medindo cerca de $3,0 \times 2,6 \times 3,7 \mathrm{~cm}$ foi observada na região dorsocentral do abdômen, ligeiramente a direita, logo caudal ao pólo caudal do rim direito. Material hipotenso é visto em cólon descendente. Múltiplas áreas hipotensas pontuais foram vistas no parênquima esplênico.

As impressões iniciais foram:

1. Mielopatia extradural com discreta hidromielia cranial, causada por material discal e a direita em T12-13; 
2. Discretas protusões do ânulo fibroso em L1-2 e L6-7, sem repercussões medulares;

3. Provável dilatação cecal por conteúdo hipointenso. A possibilidade de linfonodomegalia ileocecocólica (reativa a inflamação ou infiltração neoplásica), neoplasia ou granuloma cecal não podem ser totalmente excluídas. Caso seja clinicamente indicado, ultrassonografia abominal é sugerida para caracterização complementar;

4. Sacralização de L7, achado incidental;

5. Provável deposição multifocal de ferro no baço, achado incidental.

Algumas das alterações citadas nas impressões apresentadas anteriormente podem ser observadas na figura 13, a seguir: 


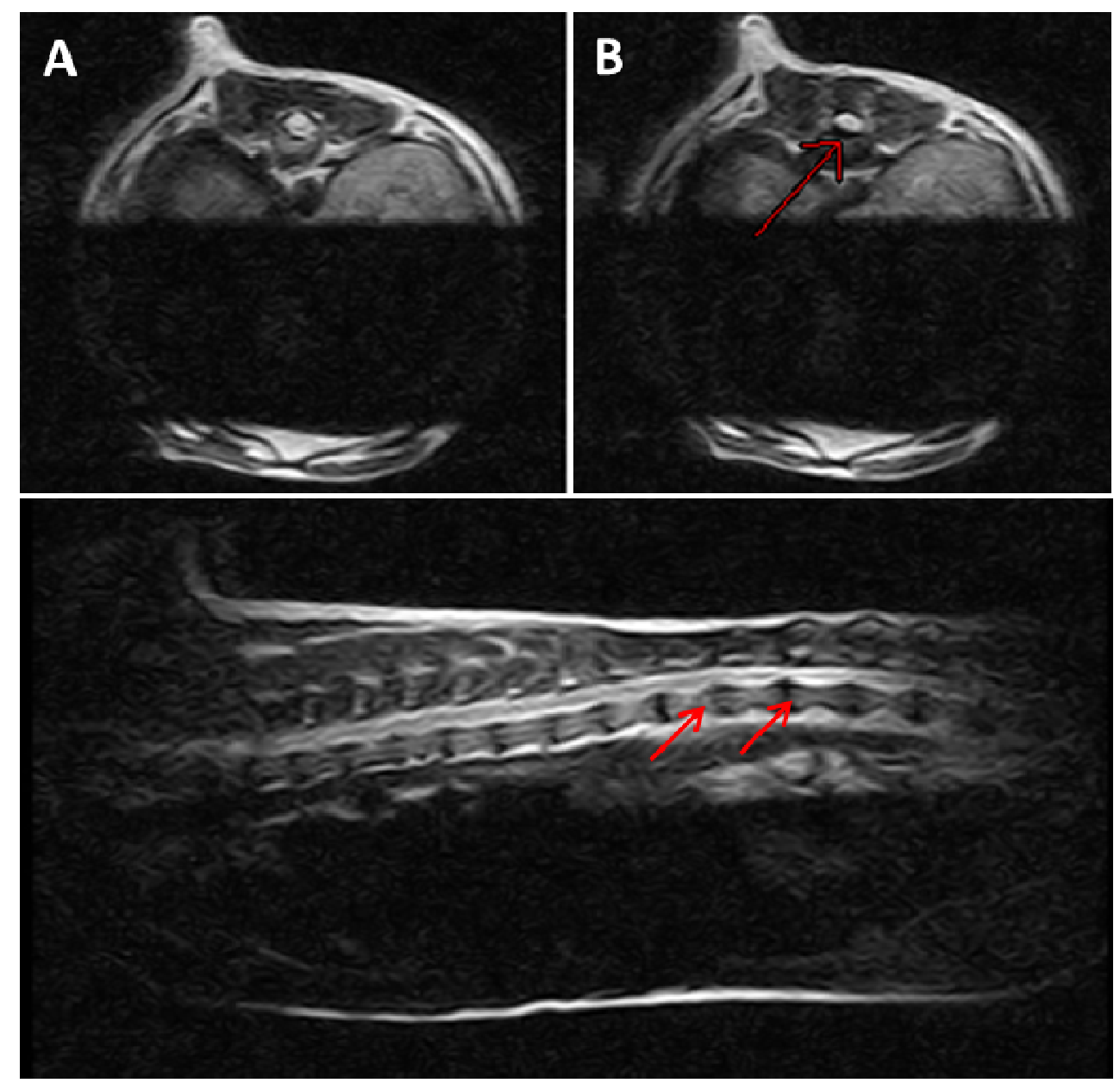

Figura 13 - Ressonância magnética da coluna vertebral toracolombar de cão da raça Ihasa apso. A - Dilatação fluida do canal central medular anterior à compressão de T12-13. B - Compressão medular ventral e a direita em T12-13 apontada pela seta vermelha. C - Extrusão discal em T12-13 e protusão discal em L1-2 
Após a ressonância magnética pré-operatória foi marcada a cirurgia de descompressão medular. Em virtude da maior quantidade de material extrusado se encontrar no lado direito do canal medular, o mesmo foi disposto em decúbito lateral esquerdo e a medula foi acessada através de corpectomia associada à pediculectomia (Figura 14-A). Assim que a medula espinhal foi acessada, notou-se a presença de um grânulo fibroso de aproximadamente $2,5 \mathrm{~mm}$ aderido firmemente a dura-máter que foi retirado delicadamente dando a possibilidade de visualização de uma medula com aspecto edemaciado (Figura 14-B, C). Foram diluídas $1 \mathrm{X} 10^{6}$ células em $300 \mu$ de PBS, que foram apresentadas ao neurocirurgião em tubos eppendorf, o qual retirou as mesmas com seringa de $0,5 \mathrm{ml}$ aplicando $100 \mu \mathrm{l}$ em três pontos da medula espinhal (anterior, posterior e no centro da lesão medular) (Figura 14-D, E). Procedeu-se a sutura de músculos e pele como de rotina (Figura 14-F). 


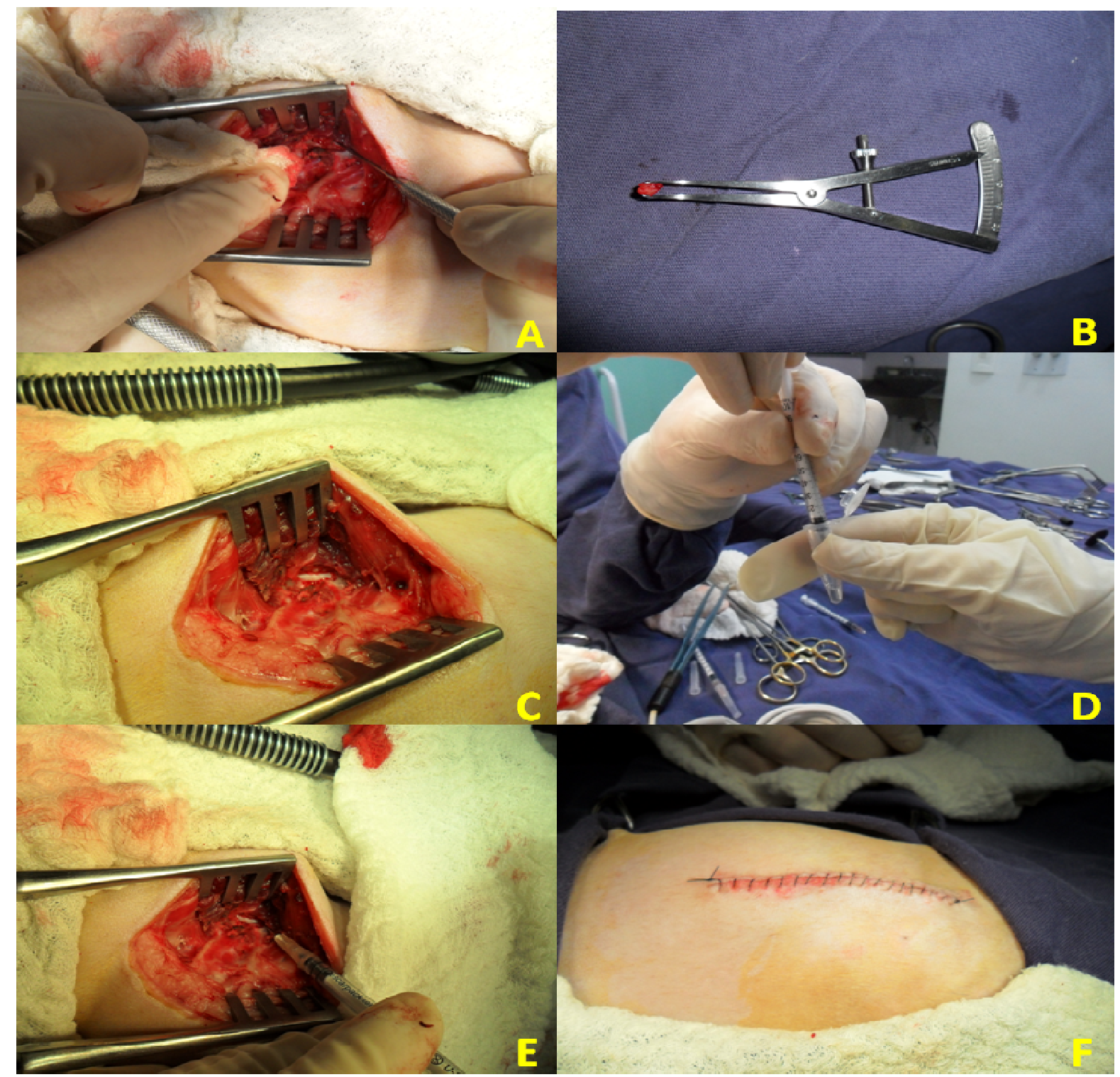

Figura 14 - Fotografias evidenciando a técnica de transplante de Células Tronco da Polpa Dentária Humana Imatura em cão da raça Ihasa apso. A - Material extrusado do núcleo pulposo do disco intervertebral firmemente aderido a dura-máter. B - Grânulo de fibrina que se encontrava aderido a duramáter da medula espinhal do cão. C - Aspecto da medula espinhal após retirada do grânulo da medula espinhal. D - Retirada das células-tronco da polpa dentária humana de ependorf, para posterior aplicação no foco da lesão medular. E - Aplicação das células-tronco da polpa dentária humana no foco da lesão medular. F - Aspecto final da cirurgia 
Após os 10 dias de pós-operatório inicial e retirada dos pontos o animal foi encaminhado à fisioterapia veterinária, onde realizou 3 sessões por semana de fisioterapia, em esteira aquática, e readequando a sua propriocepção. Não foram usadas ferramentas fisioterápicas para reduzir o processo inflamatório, de forma a não intervir no resultado da terapia celular, tendo em vista que as células-tronco apresentam quimiotaxia por tecido inflamatório.

O animal foi filmado para realização do teste comportamental de Olby et al. (2001) nos tempos pré-operatório, 15, 30 e 60 dias após a realização da cirurgia . As filmagens pré-operatórias foram avaliadas por 3 profissionais da área de fisioterapia veterinária, e os resultados das filmagens foram dispostos na forma de gráfico a seguir (Gráfico 2).

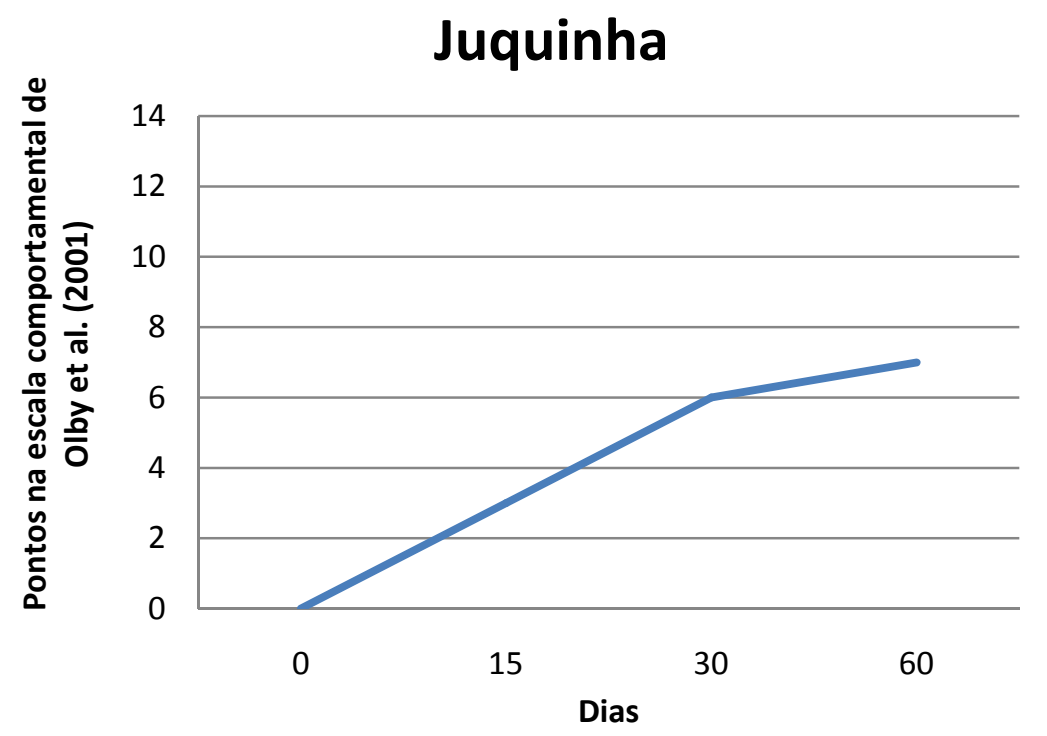

Gráfico 2 - Teste comportamental de Olby et al. (2001) realizado em cão da raça Ihasa apso submetido à terapia celular com células tronco da polpa dentária imatura humana 
No dia do procedimento cirúrgico foi realizada a primeira filmagem referente ao dia 0 . São observadas movimentações irregulares dos membros posteriores, muito embora o animal não suportasse o próprio peso (Anexo G) (FEITOSA, 2010e). Com base nesses dados e na observação de 3 profissionais da área de fisioterapia veterinária esse animal recebeu um escore 3.

Quinze dias após o procedimento cirúrgico foi realizada outra avaliação comportamental através de filmagens. Não houveram alterações no quadro inicial, e o animal recebeu o mesmo escore inicial (Anexo H) (FEITOSA, 2011 f), .

Trinta dias depois realizamos nova filmagem, dessa vez em esteira aquática. Nesse vídeo podemos ver o animal deambulando com total movimento de ambas as articulações do membro pélvico, cruzando os membros algumas vezes e com hiperextensão de alguns passos. O mesmo conseguia deslocar o próprio peso por um curto espaço de tempo, e por isso atingiu o escore 6 nessa filmagem (Anexo I) (FEITOSA, 20119).

Sessenta dias após o transplante das células realizamos a última filmagem deste animal (Anexo J) (FEITOSA, 2011 ${ }^{\mathrm{h}}$ ). Podemos observar o movimento coordenado das articulações dos membros pélvicos, com deslocamento do peso em $50 \%$ do tempo quando se retira o fator gravidade, como no caso do animal em esteira aquática, ou com o peso suportado. Sem apoio o animal por várias vezes 
tentava se manter em postura quadrupedal, o que já não ocorria há mais de dois anos, segundo relatos do proprietário. Com isso chegamos a um escore 7 no sistema de avaliação de Olby.

Após 3 meses a contar do transplante de células tronco da polpa dentária humana imatura, procedeu-se novo exame de ressonância magnética por imagem. Diminuição do sinal de forma multifocal dos discos intervertebrais, em diferentes graus, foi observada ao longo da coluna toracolombar. Na altura do espaço intervertebral de T12-12. Estrutura hipotensa foi novamente vista em posição ventral e a direita, causando leve compressão da medula espinhal, na altura do forame intervertebral, entretanto este grau de compressão está diminuído em volume desde o estudo anterior. Dilatação fluida focal do canal central da medula espinhal é vista novamente, cranial a esta lesão supramencionada, na altura do corpo vertebral de T12. Ausência do pedículo vertebral direito de T12 foi notado, associado à assimetria, diminuição de volume e hiperintensidade irregular focais da musculatura paravertebral direita, em comparação a musculatura contralateral. Estes últimos achados da fase anterior são compatíveis com intervenção cirúrgica vertebral prévia, como relatado. 
Impressões (Figura 15):

1. Leve protusão discal ventral e a direita em T12-13, diminuída em tamanho desde o estudo anterior (hemilaminectomia direita em T12, posterior ao estudo anterior), com siringo/hidromielia focal persistente em T12-13, provavelmente sequela da protusão discal/compressão medular, que era mais evidente no estudo anterior.
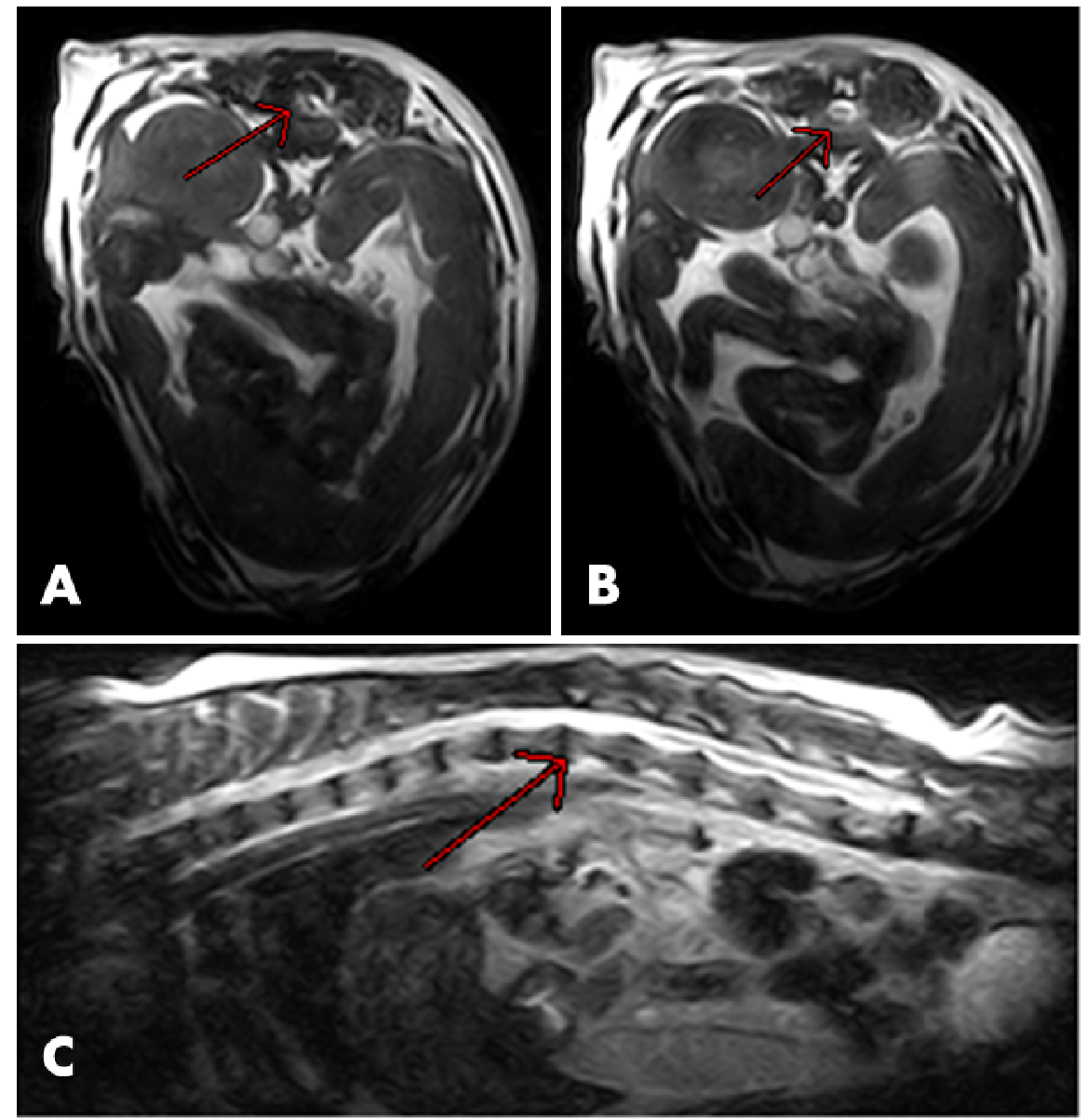

Figura 15 - Ressonância magnética de cão da raça Ihasa apso após 3 meses da realização do transplante das células tronco da polpa dentária humana imatura. A - Mini hemilaminectomia realizada em vértebra T12. B - Dilatação do canal central da medula espinhal e algum conteúdo discal extruído ventral e a direita. C - Aumento do hipersinal medular e compressão ventral da medula espinhal. Setas vermelhas apontam o local exato das observações. 
Sem mais nenhuma evolução clínica apresentada pelo animal em 4 meses de observação pós-operatória, seguimos em diante com novos casos clínicos.

\section{CASO CLÍ NICO 2}

Cão de nove anos de idade, macho da raça daschund, perdeu os movimentos dos membros pélvicos há 1 ano e meio. Nunca foi operado. Há um ano realiza sessões de ozonioterapia. Ausência de reflexos de dor profunda e superficial com presença dos reflexos de retirada dos membros.

Hemograma normal, eletrocardiograma sem alterações significativas. O laudo da ressonância magnética e considerações seguem: Considera-se neste estudo T13 a vértebra mais caudal que possui costelas. Diminuição do hipersinal normal, na sequência T2, de todos os discos intervertebrais inclusos neste estudo foi observado em diferentes graus, sendo mais evidente nos discos intervertebrais torácicos caudais. Material hipotenso foi visto na porção ventral central (discretamente à direita) do canal vertebral em L4-5, causando compressão medular moderada a severa, diminuindo a altura medular em cerca de $50 \%$. 
Entretanto, não há alteração do sinal medular neste local. Leve supressão do sinal epidural ventral foi visto em T9-10, T12-13 e T13-L1. Na altura dos corpos vertebrais de T13-L1, hipersinal medular relativamente homogêneo foi visto, ora ocupando todo o diâmetro medular, ora ocupando a porção dorsal da medula, sendo que, algumas destas áreas (porção central da medula espinhal na altura de T12 e porção dorsal da medula na altura de L1) estavam hipointensas na sequência T1. Hipersinal focal central medular foi visto na altura dos corpos vertebrais de T11, T12, T13, L1 e L2. Estrutura arredondada, hipointensa na sequência T2, foi vista na cabeça do baço, medindo cerca de $1 \mathrm{~cm}$ de diâmetro. Não há realce anormal de estruturas pós-contraste.

Impressões iniciais (Figura 16):

1. Mielopatia extradural compressiva moderada a severa ventral central em L4-5.

2. Áreas de necrose, gliose ou hemorragias focais na altura de T13 e L1, com provável siringohidromielia de T11 a L2.

3. Leves protusões discais em T9-10, T12-13 e T13-L1, sem compressão medular importante.

4. Desidratação/degeneração discal multifocal na coluna toracolombar, como acima descrito.

5. Nódulo esplênico. Principais diferenciais incluem acúmulo férrico, hiperplasia noduar, hematopoese extramedular ou, menos provável infiltração neoplásica. 

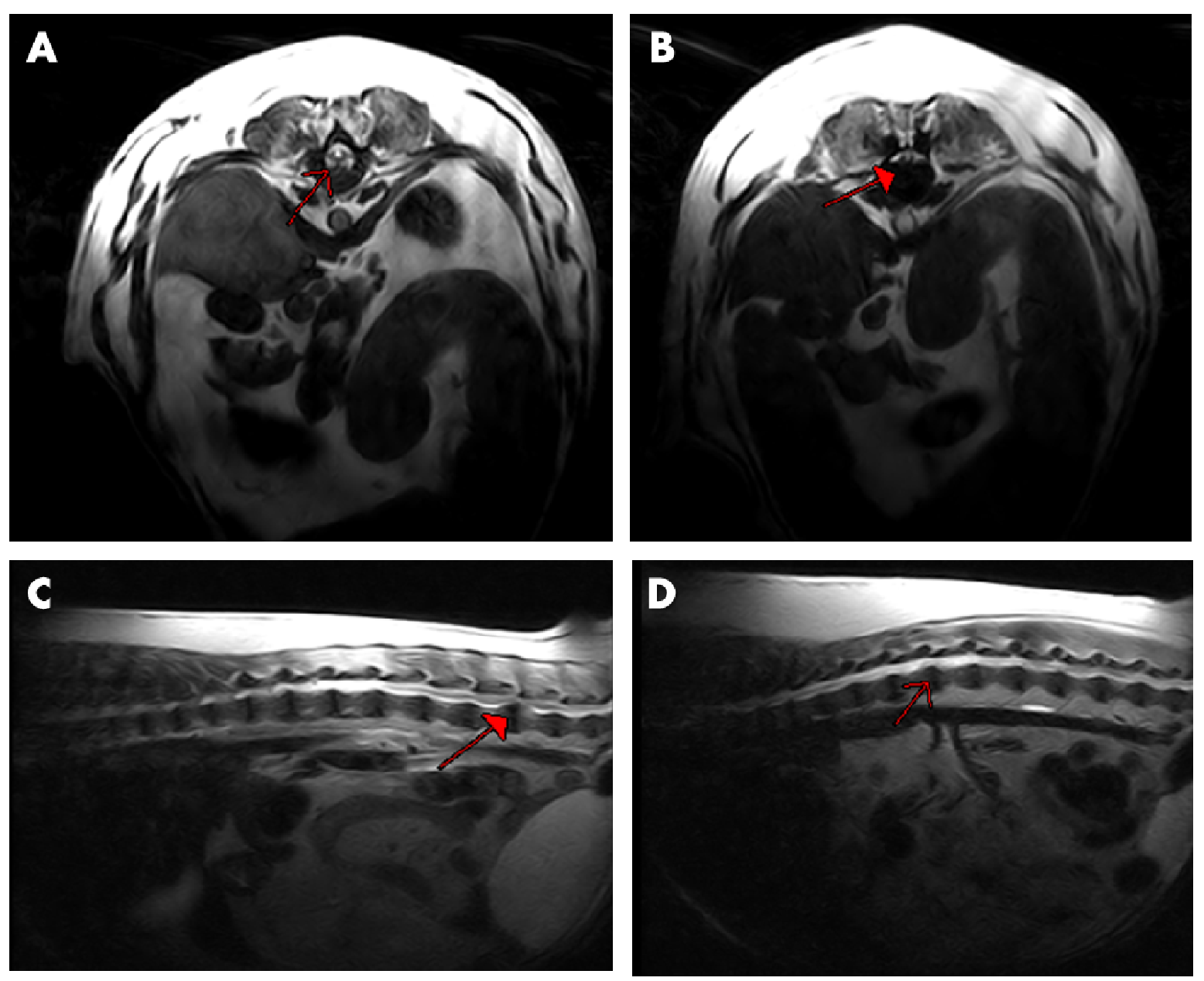

Figura 16 - Ressonância Magnética da coluna toracolombar de cão da raça Daschund. A - Aumento do canal central medular e conteúdo comprimindo a medula em porção lombar em pequena quantidade. B - Extrusão discal com compressão medular severa em L4-5. C - Compressão medular severa em L4-5. D - Área de aparente necrose medular espinhal em T13-L1. Setas vermelhas indicam o local exato das observações

Após o recebimento do laudo da Ressonância Magnética procedeuse as filmagens pré-operatórias para avaliação através da escala comportamental de Olby et al. (2001). Três fisioterapeutas veterinárias assistiram as filmagens pré-operatórias e consideraram um score de 0 para este animal (Anexo K) (FEITOSA, 2011'). Pouco ou nenhum movimento da cauda. Não se pode observar nenhuma movimentação das 
articulações. O animal apresenta o reflexo de retirada preservado, muito embora não apresente os reflexos de dor superficial nem profunda. 0 reflexo de propriocepção dos dois membros ainda se encontra preservado neste animal.

Após a realização da pediculectomia associada à corpectomia, com auxílio de drill pneumático (Figura 17-A), procedeceu-se a retirada de material proveniente do núcleo pulposo extruído de dentro do canal medular. A medula encontrava-se com material do disco intervertebral aderido a dura-máter, que foi gentilmente retirada com auxílio de delicadas pinças odontológicas (Figura 17-B). A medula foi facilmente visualizada após retirada do nucleo pulposo dos discos intervertebrais, apresentando bom aspecto geral (Figura 17-C). Foram realizadas 3 aplicações de $1 \times 10^{6}$ células tronco da polpa dentária humana imatura, diluídas em $300 \mu \mathrm{l}$ de PBS, sendo duas aplicações de $100 \mu$ l cada nos espaços intervertebrais T11-12 e T12-13, e mais $100 \mu \mathrm{l}$ no espaço L4-5 (17-D). 


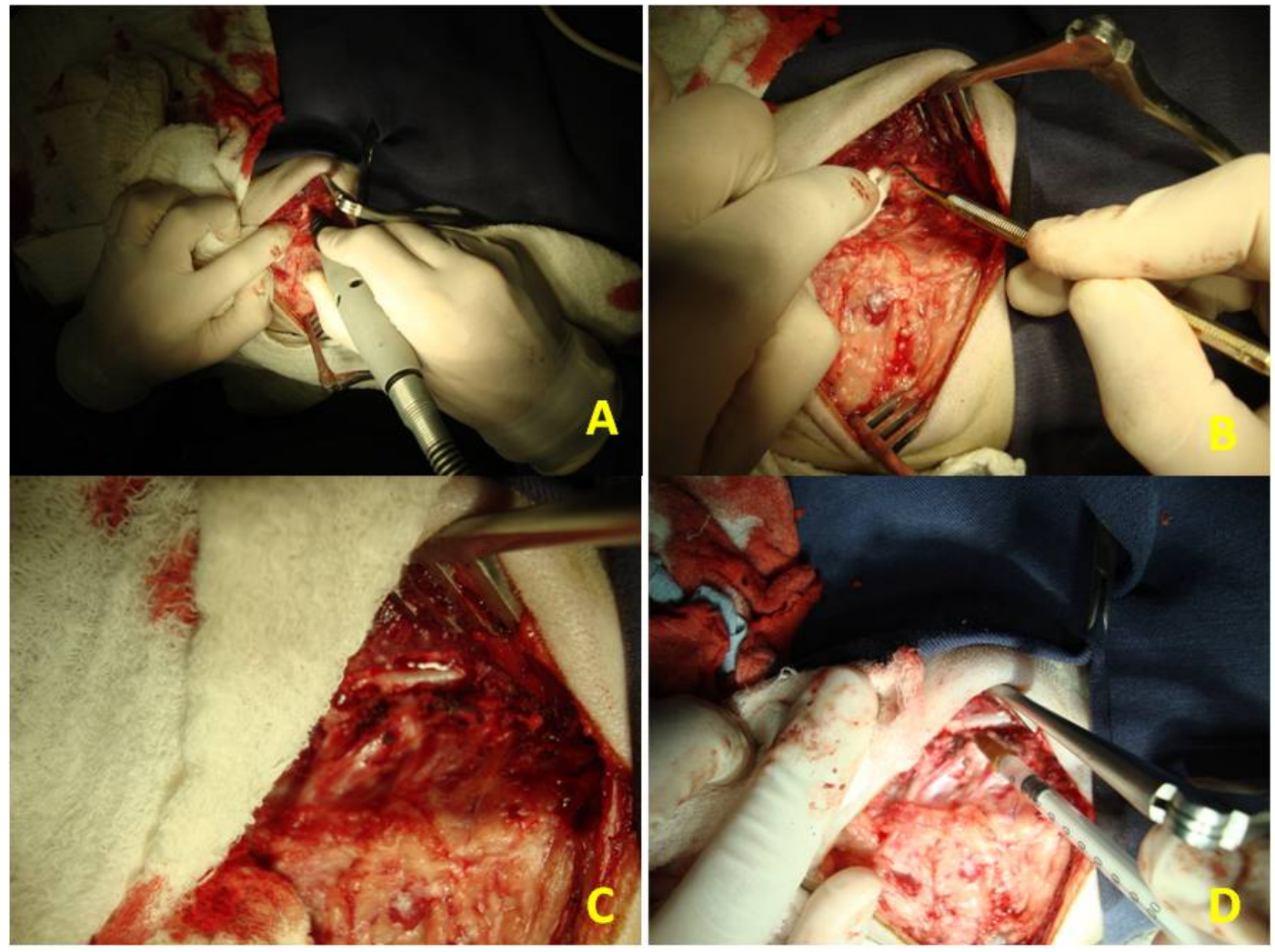

Figura 17 - Fotografias da técnica de transplante de células-tronco da polpa dentária humana imatura em cão da Daschund. A - Realização do acesso à medula espinhal com auxílio do drill pneumático. B Retirada de material do núcleo pulposo calcificado, firmemente aderido à dura-máter da medula espinhal. C - Apresentação da medula espinhal após retirada de material calcificado, aderido a dura-máter. D - Aplicação das células-tronco da polpa dentária humana imaturas no foco da lesão medular

Quinze dias após o procedimento realizou-se a primeira filmagem pós-operatória para fins de pontuação na escala comportamental de Olby et al. (2001). Com alguma movimentação das articulações dos membros pélvicos, o animal recebeu um escore 3 (Anexo L) (FEITOSA, 2011 $1^{j}$.

Trinta dias após o procedimento cirúrgico o animal pontuou 3 pontos novamente (Anexo M) (FEITOSA, 2011 $1^{\mathrm{k}}$ ).

Por fim, após sessenta dias da intervenção cirúrgica o animal pontuou 4 pontos na escala comportamental de Olby. O animal 
consegue deslocar o próprio peso por curtos espaços de tempo, e deambula mesmo em esteira seca. Considerou-se o melhor resultado obtido dentre os animais estudados (Anexo N) (FEITOSA, 2011').

Procedeu-se a avaliação através de ressonância magnética por imagem do segmento toracolombar da coluna vertebral, comparado ao estudo anterior. Sequências ponderadas em T2 nos planos sagital e transversal, dorsal STIR e transversal em "3DHyce" foram adquiridas.

Considerou-se no estudo T13 a vértebra mais cauda, que possui costelas. Diminuição do hipersinal normal, em T2, de todos os discos intervertebrais inclusos neste estudo, foi observado em diferentes graus. Material hipotenso foi visto na porção mediana e a direita em L4-5 causando compressão medular severa. Entretanto, não há alteração evidente do sinal medular neste local. Leve supressão do sinal epidural ventral é visto em T12-13 mais evidente do lado direito, e em L5-6. Dilatação fluida e ondulante do canal central foi visto na altura dos corpos vertebrais de T11 a L3. De forma subjetiva, diminuição do diâmetro da medula espinhal foi vista na altura de T13-L1. Alargamento dos forâmes intervertebrais direitos de T13-L1 e L3-4, com preservação da faceta articular, foi observado. $\mathrm{Na}$ altura de T13 até pelo menos L6, diminuição do volume e hipersinal na sequência T2, foi visto na musculatura paravertebral direita e esquerda. A cerca de $25 \mathrm{~mm}$ a direita do espaço intervertebral de L3-4, nos tecidos subcutâneos, pequena área é vista 
causando artefato de susceptibilidade metálica. O polo cranial direito da adrenal direita está assimetricamente maior, medindo $9 \mathrm{~mm}$ de altura.

Impressões (Figura 18):

1. Provável atrofia medular de T31-L1, e siringohidromielia cranial e caudal de T11 a L3;

2. Mielopatia extradural compressiva severa em L4-5, sem alterações desde o estudo anterior;

3. Desidratação/degeneração discal multifocal na coluna toracolombar, como acima descrito;

4. Leve protusões discais em T12-13 e L5-6, sem compressão medular significante;

5. Intervenção cirúrgica prévia em T13-L1 e L3-4 à direita (minihemilaminectomia possivelmente);

6. Atrofia da musculatura paravertebral lombar direita e esquerda

7. Corpo estranho metálico nos tecidos moles a direita do espaço intervertebral de L3-4;

8. Hiperplasia ou nódulo no polo cranial da adrenal a direita. 

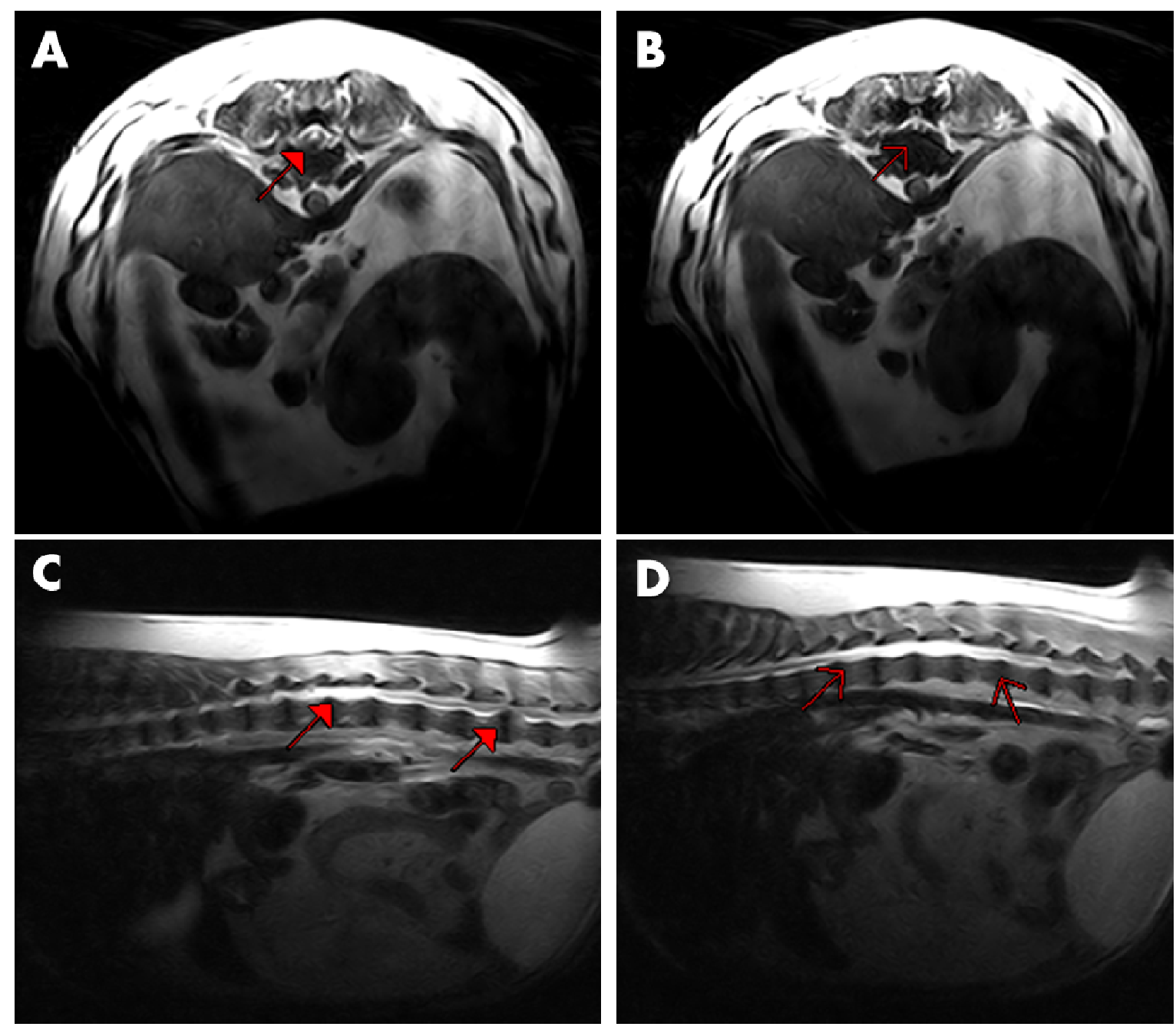

Figura 18 - Ressonância Magnética da coluna toracolombar de cão da raça Daschund. A - Aumento do canal central medular e conteúdo comprimindo a medula na altura dos espaços intervertbrais T13-L1 em pequena quantidade no assoalho do canal vertebral. B - Extrusão discal com compressão medular severa em L4-5, ventral e a direita. C - Compressão medular severa em L4-5 e aumento do hipersinal epidural desde T13 até L1. D Siringohidromielia de T11 até L1. Setas vermelhas indicam o local exato das observações 
Um quadro de piora da medula espinhal foi encontrado nesse caso, apesar da aparente melhora clínica do animal. Segue gráfico (Gráfico 3) da avaliação comportamental ao qual o animal foi submetido:

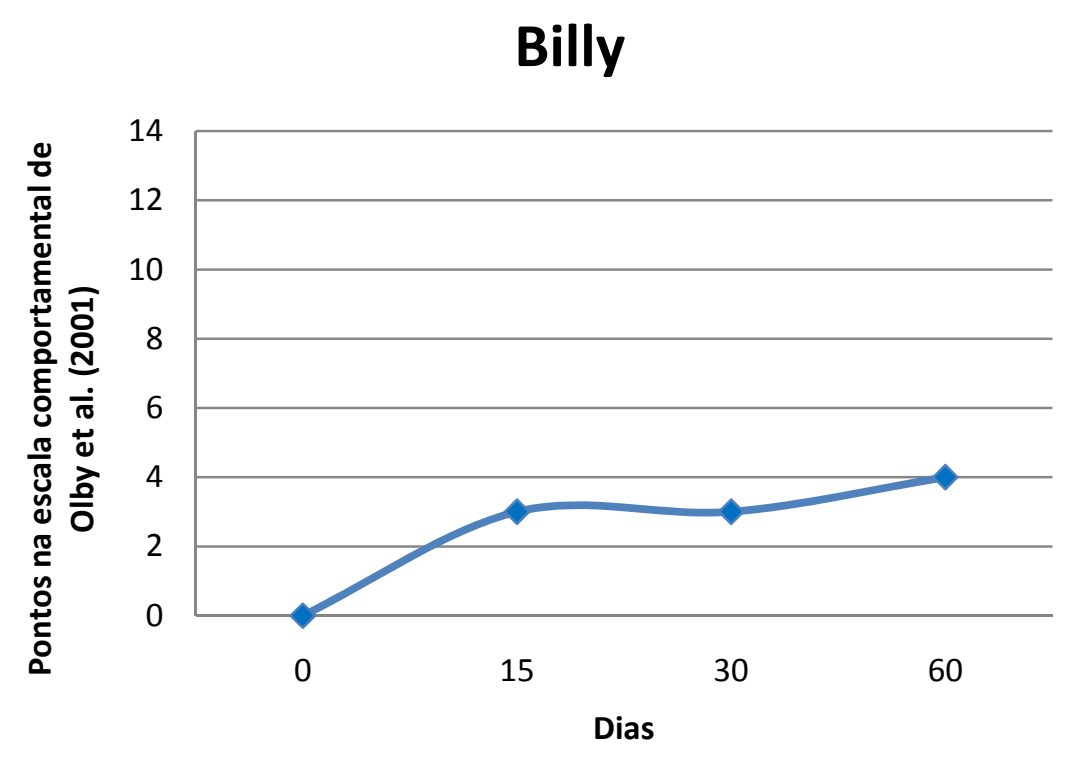

Gráfico 3 - Gráfico do teste comportamental de Olby et al. (2001) realizado em cão da raça Teckel submetido à terapia celular com células tronco da polpa dentária imatura humana

\section{CASO CLÍ NICO 3}

Cão da raça yorkshire, nove anos de idade, lesão medular crônica há dois anos, realizando fisioterapia há pelo menos 1 ano. Prévia intervenção cirúrgica em T11-12. Ausência de dor superficial e profunda.

Foi realizado estudo de ressonância magnética do segmento toracolombar da coluna vertebral. Sequências ponderadas em T2 nos 
planos sagital e transversal, dorsal em STIR e transversal em "3DHyce" foram adquiridas.

Diminuição do diâmetro medular e visto em região toracolombar (principalmente de T10 a L2), sendo este sinal medular praticamente ausente na altura de T11-12 e T13-L1, na sequência T2, com consequente aumento da espessura do sinal epidural e subaracnóide adjacente circundante. Dilatação focal do canal central é visto na atura de L1. Ausência do pedículo e lâmina vertebral esquerda em T11-12 é observado, com adjacente diminuição do volume da musculatura paravertebral esquerda. Não há alterações medulares compressivas no segmento estudado. Diminuição do hipersinal normal dos discos intervertebrais de T6-L5 é visto.

Impressões (Figura 19):

1. Atrofia medular em região toracolombar (principalmente de T10 a L2) e siringohidromielia na altura de L1. Gliose, doença degenerativa, imunomediada e/ou infecciosa viral são possíveis.

2. Prévia intervenção cirúrgica, provável hemilaminectomia esquerda em T11-12 e associada atrofia muscular paravertebral adjacente.

3. Degeneração/desidratação discal "in situ" multifocal em coluna toracolombar, como descrito acima. 

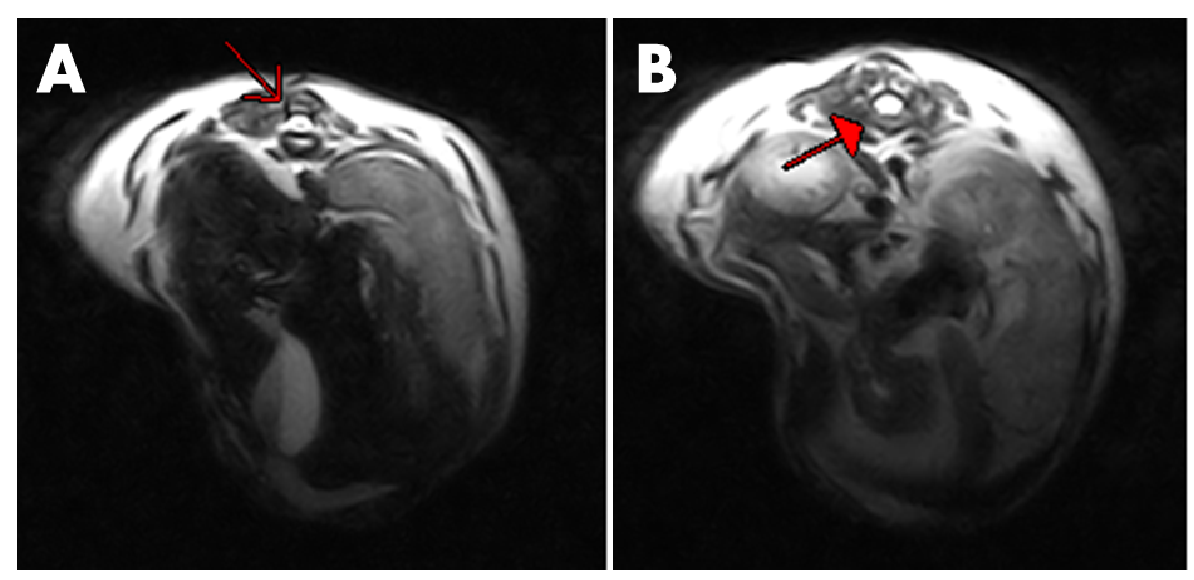

Figura 19 - Ressonância Magnética da coluna toracolombar de cão da raça Yorkshire Terrier. A - Local da intervenção cirúrgica anterior. B - Atrofia medular na altura da vértebra T11

Este animal serviu de controle para ele próprio, tendo em vista que o mesmo já realizava fisioterapia antes do experimento, e já havia sido submetido a uma intervenção cirúrgica prévia sem sucesso.

Neste animal, diferente dos demais, não foi necessária a realização de uma hemilaminectomia, pois não havia conteúdo discal extrusado no canal medular. Após a incisão da pele e musculatura paravertebral adjacente à vértebra foram realizadas 3 aplicações de $1 \times 10^{6}$ células tronco da polpa dentária humana imatura, diluídas em $300 \mu$ de PBS, sendo duas aplicações de $100 \mu \mathrm{l}$ cada nos espaços invertebrais T10-11, T11-12 e T12-13 (Figura 20). 

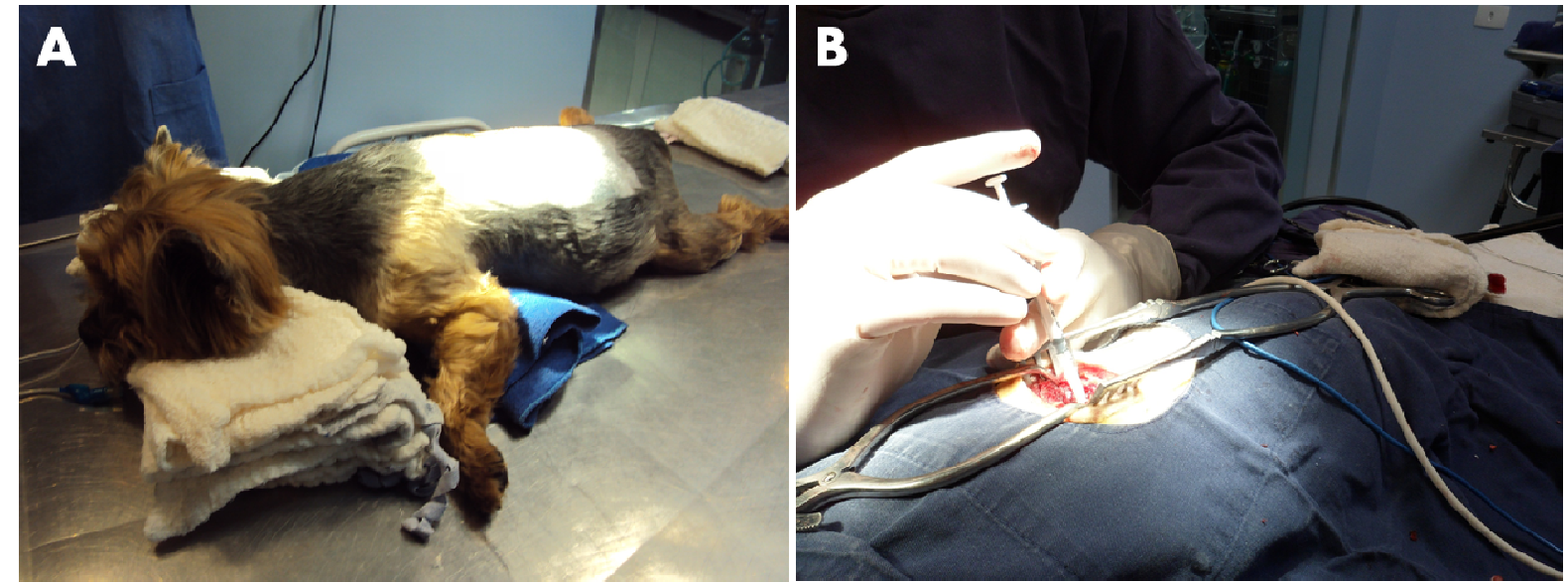

Figura 20 - Transplante de células-tronco da polpa dentária humana imatura em cão da Yorkshire. A - Cão posicionado para a realização do procedimento cirúrgico. B - Aplicação das células-tronco da polpa dentária humana no espaço intervertebral de T10-11

Seguimos com a avaliação comportamental através do teste de Olby no dia zero do experimento (Anexo O) (FEITOSA, 2011 ${ }^{\mathrm{m}}$ ). O animal não realiza qualquer movimentação das articulações dos membros pélvicos, fechando o escore zero.

Com quinze dias após a intervenção cirúrgica observamos o animal em esteira aquática deambulando com movimentação de todas as articulações dos membros pélvicos, porém sem suportar o próprio peso. Com isso fechamos em um escore 3 (Anexo P) (FEITOSA, 2011 ${ }^{\mathrm{n}}$ ).

O mesmo escore se repetiu em 30 dias. Realizou-se uma tentativa de deambulação em esteira seca, porém, o animal repetiu a incapacidade de suportar o próprio peso (Anexo Q) (FEITOSA, 2011º).

Até o momento de depósito da tese não realizamos a filmagem referente aos 60 dias de pós-operatório, e ainda não realizamos o 
segundo exame através da ressonância magnética por imagem. Obtemos o seguinte gráfico Gráfico 4:

\section{Luigi}

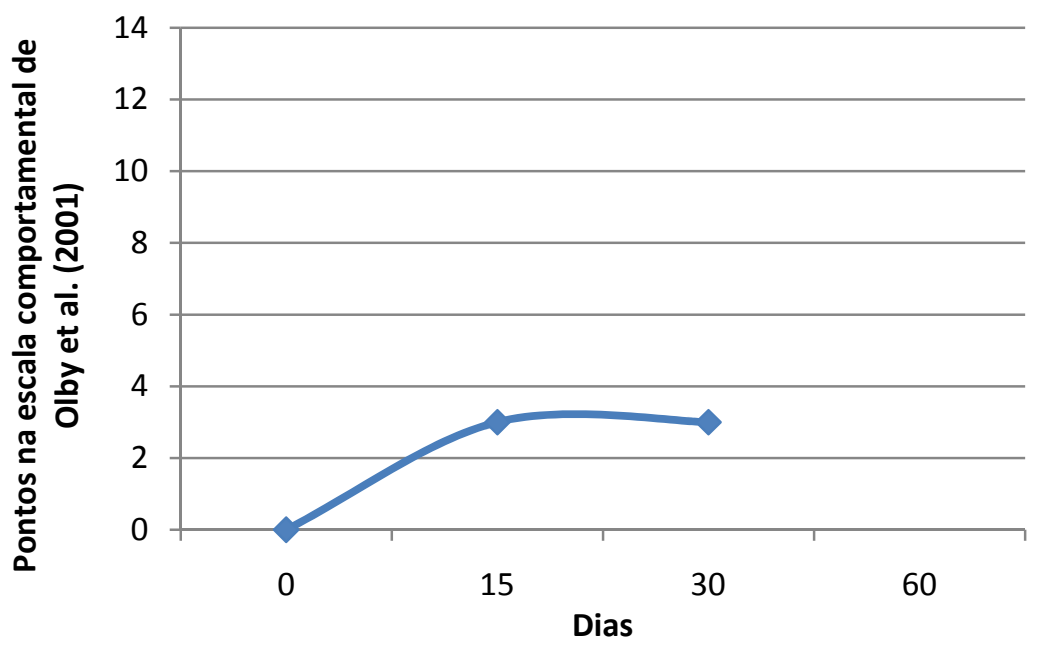

Gráfico 4 - Teste comportamental de Olby et al. (2001) realizado em cão da raça Teckel submetido à terapia celular com células tronco da polpa dentária imatura humana. 


\section{DISCUSSÃO}

Em virtude dos trabalhos existentes na literatura acerca da hemissecção dorsal em ratos (XU et al., 1995; XU et al. 1999) e dos trabalhos relevantes quanto a produção de modelos animais de lesão medular em coelhos propostos por Lyalka et al. (2009) procedeu-se um estudo para determinar qual dos modelos de hemissecção seria o mais adequado para realizar nos coelhos.

Os resultados obtidos nesse estudo com as técnicas de HD e HV, muito embora baseados apenas na avaliação clínica, corrobora com os dados obtidos por Lyalka et al. (2009). Esse autor demonstrou que a técnica de hemisecção ventral gera em coelhos um déficit locomotor onde não há recuperação do quadro clínico mesmo após 42 dias de avaliação. A maioria dos tratos espinais descendentes relacionados à locomoção está localizado na porção ventral da medula espinhal (trato rubriespinhal, reticulo espinhal e vestibuloespinhal). Isso explica o porquê da hemissecção ventral mimetizar melhor uma lesão medular crônica. Em nosso estudo, mesmo após 30 dias da realização da técnica cirúrgica de hemissecção medular ventral, os animais não retornaram a sua função normal, nem mesmo apresentaram melhora funcional.

No entanto, em virtude das diversas alterações fisiológicas nos coelhos submetidos à hemissecção ventral (Infecções secundárias do trato urinário inferior, deiscência de pontos cirúrgicos, cistite hemorrágica, pneumonias e infecção generalizada), chegamos à conclusão que o 
modelo animal de hemissecção dorsal proposto por Xu et al. (1995), e Xu et al. (1999) em ratos era o mais apropriado para a realização deste estudo. Desta forma, descartou-se a avaliação comportamental dos animais, tendo em vista que os mesmos invariavelmente retornariam a função locomotora normal, fato esse confirmado nesse experimento, dando maior ênfase ao estudo imunohistoquímico (através da análise da expressão de SCPg e rastreamento das células-tronco aplicadas através do gene repórter GFP e avaliação histopatológica.

A coleta de tecido do sistema nervoso central para avaliação histológica ou imunohistoquímica carece de atenção redobrada dos pesquisadores. Blits et al. (2005) realizaram perfusão transcardíaca de solução salina gelada após anestesia, seguida de perfusão de paraformaldeído a 4\% por via transcardíaca. Logo após coletaram o material da medula espinhal e incluíram em paraformaldeído a 4\% em temperatura de geladeira por mais 24 horas. Depois passaram este material para a sucrose a $30 \%$ até o dia de processamento. O mesmo protocolo é descrito por Ikegami et al. (2005). Realizamos o mesmo protocolo para coleta do nosso material histológico.

Após quatro semanas da lesão medular por hemissecção medular rastreamos a cicatriz da glia através da marcação com o anticorpo antisulfato de condroitina proteoglicano, mesmo em porções anteriores a lesão causada. Hu et al. (2010) relatam a formação da cicatriz da glia quatro semanas após a lesão medular causada por aparelho de impacto com peso constante, através da detecção dos astrócitos reativos com o 
anticorpo anti-GFAP (glial fibrilary acid protein). Esses autores avaliaram a presença dos astrócitos reativos na lesão medular, e consideraram que a formação da cicatriz da glia está mais claramente definida após 4 semanas da lesão medular. Muito embora não possamos afirmar que o mesmo acontece em coelhos, abre-se uma lacuna para consideração, em virtude da presença da cicatriz glial detectada aos 30 dias de lesão medular.

A cicatriz da glia é um dos principais empecilhos à regeneração da lesão medular (ROLLS et al., 2008). Estudos envolvendo a terapia celular na lesão medular carecem de maiores informações a cerca da interação da mesma com os agentes terapêuticos utilizados no seu tratamento. O uso da coloração de azul de alcian aparece como uma alternativa viável e mais barata para mensuração da cicatriz da glia no foco da lesão medular. O estudo do comportamento das células-tronco frente à barreira da cicatriz glial é de suma importância para entender os acontecimentos inerentes a uma terapia no sistema nervoso central.

Yano et al. (2005) detectaram células da medula óssea contendo a proteína verde fluorescente (green fluorescente protein - GFP) através de imunofluorescência. Os autores relatam que conseguiram rastrear suas células em três dos seis animais utilizados, sendo que 4 semanas após o transplante, conseguiram rastrear células em uma porção posterior a lesão causada. Em nosso estudo conseguimos rastrear células no foco da lesão medular e anterior a mesma, não encontrando células posteriores a lesão medular causada, indicando que ou as células não conseguiram 
ultrapassar a cicatriz glial, ou o tempo foi muito curto para que pudessem emitir feixes posteriores a lesão medular.

Blits et al. (2005) realizaram transplante de células progenitoras neurais contendo a proteína verde fluorescente na lesão medular de ratos, rastreando as mesmas mesmo após 12 semanas do transplante. Esses dados comprovam a capacidade duradoura de expressão gênica da proteína verde fluorescente in vivo. Rastreamos as células-tronco do epitélio olfatório de coelhos, transduzidas com GFP 4 semanas após o transplante celular, evidenciando assim a sobrevivência das mesmas após transplante.

Poucos trabalhos utilizam a via local (intra-medular) em ensaios clínicos em humanos para transplante das células-tronco, sendo o mais relevante deles o trabalho realizado por Mackay-Sim et al. (2008). Neste trabalho optamos por esta via na terapia celular da lesão medular em cães, por acreditar que as perdas celulares são menores quando comparadas a outras vias, tais como a via epidural, ou a via intravenosa, além de que acreditamos que o próprio nicho celular deva fornecer nutrientes e subsídios para a diferenciação das células injetadas em células de origem nervosa. Esse fato já foi confirmado em trabalhos posteriores realizados por Paul et al. (2009) em um ensaio com ratos, onde os mesmos foram divididos em três grupos (via intravenosa, punção lombar e via local) de 6 animais cada, sendo comprovada a eficiência da via epidural quando comparada a via intravenosa, e a via local como a mais efetiva para o fornecimento de células no tecido lesionado. 
O trabalho realizado por Lim et al. (2007) com cães cuja medula espinhal foi lesionada através de compressão com balão tratados com células tronco de cordão umbilical mostrou uma melhora significativa nos escores comportamentais da escala de Olby. No entanto a lesão causada nesse estudo apresentava um caráter agudo, de provável resolução espontânea. Os casos selecionados nesse trabalho apresentavam lesão medular crônica, sem nenhuma resposta aos tratamentos convencionais instituídos na medicina veterinária.

Apesar da melhora clínica comportamental apresentada pelos animais deste experimento, não há evidência de regeneração da medula espinhal após a realização da ressonância magnética pós-operatória. O mesmo foi relatado por Lim et al. (2007).

Há relatos consistentes de recuperação funcional em ratos com lesão medular tratados com células tronco mesenquimais (MSCMesenchymal Stem Cells) (HOFSTETTER et al., 2002; LEE et al., 2007). O mesmo foi constado nesse experimento utilizando as células tronco da polpa dentária humana, que são células-tronco mesenquimais.

Nosrat et al., (2001) avaliaram o potencial neurogênico das células da polpa dentária in vitro, e em ratos submetidos a hemisecção medular. A enxertia dessas células em ratos com medula hemisseccionada aumentou o número de neurônios motores sobreviventes, indicando uma bioatividade funcional. Os nossos resultados referentes à avaliação comportamental dos cães transplantados com as h-IDPSC, associados aos resultados obtidos por estes autores, nos fazem acreditar que as células 
transplantadas forneceram neurônios que promoveram uma resposta funcional nesses cães.

Estes tipos celulares "não neurais", como é o caso de nossas hIDPSC apresentam um mecanismo diferente para a recuperação das lesões medulares, onde não há a reposição de neurônios ou de células da glia (BARNABÉ-HEIDEN E FRISÉN, 2008). É bem provável que estes tipos de células forneçam suporte trófico, modulem a resposta inflamatória ou forneçam substratos para o crescimento de axônios, como eixos orientadores para a regeneração medular, promovendo a recuperação funcional (HOFSTETTER et al., 2002). Acreditamos que é através destes mecanismos que os animais utilizados neste experimento apresentaram a melhora clínica apresentada.

As células-tronco da polpa dentária humana já foram diferenciadas em tecido neuronal em condições de cultivo celular, influenciadas pelo meio de cultivo celular suplementado (KERKIS et al. 2006). Os autores relatam que estas células apresentam forte tendência para diferenciação em tecido neuronal, mesmo sem a adição de meios de cultivo específicos.

A melhora clínica apresentada nos animais deste experimento leva a acreditar que as células aplicadas se diferenciaram em células de origem nervosa, influenciadas pelas substâncias químicas geradas pelas células do nicho em que foram transplantadas. No entanto, o curto espaço de tempo de avaliação deste estudo, associada a pouca, ou nenhuma melhora física da medula espinhal destes animais, nos leva a crer que talvez nossos resultados estejam mascarados pelos resultados obtidos 
com a própria fisioterapia. No entanto, a fisioterapia faz parte de qualquer protocolo de tratamento para lesão medular, sendo impossível retirar a mesma de nosso estudo. A avaliação do potencial somatossensorial evocado, realizada por Lim et al. (2007), poderia responder a esta lacuna deixada neste experimento.

São praticamente inexistentes na literatura científica os trabalhos utilizando cães com lesão medular espontânea em testes clínicos com terapia celular e célula-tronco, estando restritos a trabalhos experimentais, nos quais os autores causam a lesão medular nos animais (LIM et al., 2007; RYU et al., 2009). Neste trabalho optamos por usar animais com a lesão medular espontânea, em virtude do acometimento contínuo das lesões medulares em cães, e da possibilidade de avaliar os resultados da terapia celular com células-tronco em uma situação real.

Richardson et al. (1980) implantaram axônios do sistema nervoso central no sistema nervoso periférico e relataram o crescimento dos mesmos nesse novo nicho celular. A partir desse estudo, se pôs por terra a teoria de que as células do sistema nervoso central possuiriam uma capacidade regenerativa limitada, e se iniciou estudos aprofundados a cerca da patofisiologia da lesão medular.

Embora tenhamos obtidos melhoras significativas nos cães tratados, nossos resultados confirmam os achados de Eva Sykova et al. (2006), que afirma que em lesões completas e muito extensas, somente a aplicação de células-tronco não é suficiente para a reparação do tecido, 
sendo necessário uma busca por alternativas que complementem a ação das células e preencham a lacuna causada pela morte do tecido.

Trabalhos mais atuais apostam na resolução da cicatriz da glia associadas às terapias com células tronco para o tratamento da lesão medular crônica (IKEGAMI et al., 2005; SIEBERT et al., 2011). A imunização com vacina recombinante que atua no sítio de ligação dos inibidores de crescimento axonal (Nogo A, AMG e OMP) nas células axonais (YU et al., 2008) e mesmo o tratamento com anticorpos antiNogo A (FREUND et al., 2009) parecem o futuro das terapias na lesão medular. O conjunto dessas terapias associada à terapia com as células tronco podem representar uma esperança bastante realista na busca da cura das lesões medulares. 


\section{CONCLUSÕES}

A técnica de hemissecção medular ventral em coelhos é a que melhor mimetiza uma lesão medular crônica, no entanto, os problemas pós-operatórios associados à realização desta técnica invalidam esse modelo experimental.

As células-tronco do epitélio olfatório de coelhos foram eficientemente rastreadas na medula de coelhos submetidos à hemissecção medular dorsal através da detecção do GFP nas células injetadas 4 semanas após o transplante.

Após 4 semanas da lesão medular em coelhos é possível rastrear a cicatriz glial.

A terapia celular com células-tronco da polpa dentária humana em cães com lesão medular crônica é uma técnica factível, e não representa riscos ao animal. 


\section{REFERÊNCI AS}

AUDISIO, C.; RAIMONDOB, S.; NICOLINO, S.; GAMBAROTTA, G.; DI SCIPIO, F.; MACRI, L.; MONTAROLOC, F.; ROBECCHI, M. G. G.; PORPORATO, P.; FILIGHEDDU, N.; GRAZIANI, A.; GEUNA, S.;

PERROTEAU, I. Morphological and biomolecular characterization of the neonatal olfactor $y$ bulb ensheathing cell line. Journal of

Neuroscience Methods. v.185, p. 89-98, 2009.

ZIZI, S. A.; STOKES, D.; PROCKOP, D. J. Survival, migration and engraftment of bone marrow stromal cells into the striatum of the adult rats. Experimental Neurology, v. 153, n. 2, p. 374-375, 1998.

BAPTISTE, D. C.; FEHLINGS, M. G. Update on the treatment of spinal cord injury. Progress in brain research. v. 161, p. 217-233, 2007.

BARNABE-HEIDER, F.; FRISEN, J. Stem cells for spinal cord repair. Cell Stem Cell, v. 3, n. 1, p. 16-24, 2008.

BASSO, D.M.; BEATTIE, M.S. ; BRESNAHAN, J.C. A sensitive and reliable locomotor rating scale for open field testing in rats. Journal Neurotrauma, v. 12, p. 1-21, 1995.

BELTRÃO-BRAGA, P.I.; PIGNATARI, G.C.; MAIORKA, P.C.; OLIVEIRA, N.A.; LIZIER, N.F.; WENCESLAU, C.V.; MIGLINO, M.A.; MUOTRI, A.R.; KERKIS, I. Feeder-free derivation of induced pluripotent stem cells from human immature DP stem cells. Cell Transplant, 2011. [Epub ahead of print].

BIANCO, P.; RIMINUCCI, M.; GRONTHOS, S.; ROBEY, P. G. Bone marrow stromal stem cells: Nature, biology, and potential applications. Stem Cells, v. 19, n. 3, p. 180-192, 2001. 
BIANCO, JI; PERRY, C.; HARKIN, D.G.; MACKAY-SIM, A.; FERON, F. Glia, v.45, n.2, p. 111-123, 2004.

BLITS, B.; KITAY, B.M.; FARAHVAR, A.; CAPERTON, C.V.; DIETRICH, W.D.; BUNGE, M.B. Lentiviral vector-mediated transduction of neural progenitor cells before implantation into injured spinal cord and brain to detect their migration, deliver neurotrophic factors and repair tissue.

Restorative Neurology Neuroscience, v. 23, n. 5-6, p. 313-24, 2005.

CAO, F.J.; FENG, S. Q. Human umbilical cord mesenchymal stem cells and the treatment of spinal cord injury. Chinese Medical J ournal (Engl), v. 122, p. 225-231, 2009.

CAPECCHI, M.R. The new mouse genetics: Altering the genome by gene targeting.Trends in Genetics, v. 5, p. 70-76, 1989.

D'AQUINO, R.; PAPACCIO, G.; LAINO, G.; GRAZIANO, A. Dental pulp stem cells: a promising tool for bone regeneration. Stem Cells Rewier, v. 4, n. 1, p. 21-26, 2008.

DOUCETTE R. Glial influences on axonal growth in the primary olfactory system. Glia, v. 3, n. 6, p. 433-449. 1990.

FAULKNER, J.; KEIRSTEAD, H. S. Human embryonic stem cell-derived oligodendrocyte progenitors for the treatment of spinal cord injury. Transplant I mmunology, v. 15, n. 2, p. 131-142, 2005.

FEITOSA, M.L.T. Deambulação de coelho 30 dias após hemissecção dorsal da medula espinhal. São Paulo, 2010ª (CD).

FEITOSA, M.L.T. Deambulação de coelho 30 dias após hemissecção dorsal da medula espinhal. São Paulo, 2010 (CD). 
FEITOSA, M.L.T. Avaliação do reflexo de dor profunda em coelho após hemissecção ventral da medula espinhal. São Paulo: FEITOSA, M.L.T. $2010^{c}(C D)$.

FEITOSA, M.L.T. Avaliação do reflexo de dor profunda em coelho após hemissecção ventral da medula espinhal. São Paulo: FEITOSA, M.L.T. $2010^{\mathrm{d}}(\mathrm{CD})$.

FEITOSA, M.L.T. Deambulação pré-operatória caso clínico 1. São Paulo: FEITOSA, M.L.T. $2010^{\mathrm{e}}$ (CD).

FEITOSA, M.L.T. - Deambulação caso clínico 1 quinze dias após transplante das células tronco da polpa dentária humana. São Paulo: FEITOSA, M.L.T. $2011^{\mathrm{a}}$ (CD).

FEITOSA, M.L.T. Deambulação caso clínico 1 trinta dias dias após transplante das células tronco da polpa dentária humana. São Paulo: FEITOSA, M.L.T. $2011^{\text {b }}$ (CD).

FEITOSA, M.L.T. Deambulação caso clínico 1 sessenta dias transplante das células tronco da polpa dentária humana. São Paulo: FEITOSA, M.L.T. $2011^{\mathrm{C}}(\mathrm{CD})$.

FEITOSA, M.L.T. Deambulação pré-operatória caso clínico 2. São Paulo: FEITOSA, M.L.T. $2011^{\mathrm{d}}$ (CD).

FEITOSA, M.L.T. Deambulação caso clínico 2 quinze dias após transplante das células tronco da polpa dentária humana. São Paulo: FEITOSA, M.L.T. $2011^{\mathrm{e}}(\mathrm{CD})$.

FEITOSA, M.L.T. Deambulação caso clínico 2 trinta dias após transplante das células tronco da polpa dentária humana. São Paulo: FEITOSA, M.L.T. $2011^{f}(C D)$. 
FEITOSA, M.L.T. Deambulação caso clínico 2 sessenta dias após transplante das células tronco da polpa dentária humana. São Paulo: FEITOSA, M.L.T. $2011^{g}$ (CD).

FEITOSA, M.L.T. Deambulação pré-operatória caso clínico 3. São Paulo: FEITOSA, M.L.T. $2011^{\text {h }}$ (CD).

FEITOSA, M.L.T. - Deambulação caso clínico 3 quinze dias após transplante das células tronco da polpa dentária humana. São Paulo: FEITOSA, M.L.T. $2011^{i}$ (CD).

FEITOSA, M.L.T. Deambulação caso clínico 3 trinta dias após transplante das células tronco da polpa dentária humana. São Paulo: FEITOSA, M.L.T. $2011^{\mathrm{j}}(\mathrm{CD})$.

FREUND, P.; SCHMIDLIN, E.; WANNIER, T.; BLOCH, J.; MIR, A.; SCHWAB, M.E.; ROUILLER, E.M. Anti-Nogo-A antibody treatment promotes recovery of manual dexterity after unilateral cervical lesion in adult primates--reexamination and extension of behavioral data. European J ournal of Neuroscience, v. 29, n. 5, p. 983-96, 2009.

FUKUDA, S.; NAKAMURA, T.; KISHIGAMI, Y.; ENDO, K.; AZUMA, T.; FUJ IKAWA, T.; TSUTSUMI, S.; SHIMIZU, Y. New canine spinal cord injury model free from laminectomy. Brain Research Protocols, v. 14, n. 3, p. 171-180, 2005.

GRONTHOS, S.; BRAHIM, J.; LI, W.; FISHER, L. W.; CHERMAN, N.; BOYDE, A.; DENBESTEN, P.; ROBEY, P. G.; SHI, S. Stem cell properties of human dental pulp stem cells. J ournal of Dental Research, v. 81, n. 8, p. 531-535, 2002.

HANNOUCHE, D.; RAOULD, A.; NIZARD, R. S.; SEDEL, L.; PETITE, H. Embedding of bone samples in methylmethacrylate: A suitable method for tracking LacZ mesenchymal stem cells in skeletal tissues. J ournal of Histochemistry \& Cytochemistry, v. 55, p. 255-262, 2007. 
HASSAN, H. T.; EL-SHEEMY, M. Adult bone-marrow stem cells and their potential in medicine. J ournal of the Royal Society of Medicine, v. 97, p. 465-471, 2004.

HOFSTETTER, C. P.; SCHWARZ, E. J.; HESS, D.; WIDENFALK, J .; EL MANIRA, A.; PROCKOP, D. J.; OLSON, L. Marrow stromal cells form guiding strands in the injured spinal cord and promote recovery. Disponível em <http://www. pnas. org/content/99/4/2199. full. pdf+html>. Acesso em: 31 de outubro de 2010.

HU, R.; ZHOU, J.; LUO, C.; LIN, J.; WANG, X.; LI, X.; BIAN, X.; LI, Y.; WAN, Q.; YU, Y.; FENG, H. Glial scar and neuroregeneration: histological, functional, and magnetic resonance imaging analysis in chronic spinal cord injury. J ournal of Neurosurgy Spine, v. 13, n. 2, p. 169-80, 2010.

IKEGAMI, T.; NAKAMURA, M.; YAMANE, J.; KATOH, H.; OKADA, S.; IWANAMI, A.; WATANABE, K.; ISHII, K.; KATO, F.; FUJITA, H.; TAKAHASHI, T.; OKANO, H.J.; TOYAMA, Y.; OKANO, H. Chondroitinase $A B C$ combined with neural stem/progenitor cell transplantation enhances graft cell migration and outgrowth of growth-associated protein-43positive fibers after rat spinal cord injury. European J ournal of Neuroscience, v. 22, n. 12, p. 3036-46, 2005.

IWANAMI, A.; KANEKO, S.; NAKAMURA, M.; KANEMURA, Y.; MORI, H.; KOBAYASHI, S.; YAMASAKI, M.; MOMOSHIMA, S.; ISHII, H.; ANDO, K.; TANIOKA, Y.; TAMAOKI, N.; NOMURA, T.; TOYAMA, Y.; OKANO, H. Transplantation of human neural stem cells for spinal cord injury in primates. J ournal of Neuroscience Research, v. 80, n. 2, p. 182-190, 2005.

JOHANSSON, C. B.; MOMMA, S.; CLARKE, D. L.; RISLING, M.; LENDAHL, U.; FRISEN, J. Identification of a neural stem cell in the adult mammalian central nervous system. Cell, v. 96, n. 1, p. 25-34, 1999.

J ONES, L. L.; MARGOLIS, R. U.; TUSZYNSKI, M. H. The chondroitin sulfate proteoglycans neurocan, brevican, phosphacan, and versican are differentially regulated following spinal cord injury. Experimental Neurology, v. 182, n. 2, p. 399-411, 2003. 
KERKIS, I., A. KERKIS, D. DOZORTSEV, G.C. STUKART-PARSONS, S.M. GOMES MASSIRONI, L.V. PEREIRA, A.I. CAPLAN, H.F. CERRUTi I solation and characterization of a population of immature dental pulp stem cells expressing OCT- 4 and other embryonic stem cell markers. Cells Tissues Organs, v. 184, p.105-116, 2006.

KERKIS, I.; AMBRÓSIO, C.E.; KERKIS, A.; MARTINS, D.S.; ZUCCONI, E.; FONSECA S.A.S.; CABRAL R.M.; MARANDUBA, C.M.C.; GAIAD T.P.; MORINI A.C.; VIEIRA, N.M.; BRÓLIO, M.P.; SANT'ANNA, O.A.; MIGLINO M.A.; ZATZ, M. Early transplantation of human immature dental pulp stem cells from baby teeth to golden retriever muscular dystrophy (GRMD) dogs: local or systemic? J ournal of Translational Medicine, v.6, 2008.

KNECHT, C.D. Results of surgical treatment for thoracolumbar disc protrusion. J ournal of Small Animal Practice, v.13 n. 8, p. 449-453, 1972.

KRASSIOUKOV, A.; CLAYDON, V.E. The clinical problems in cardiovascular control following spinal cord injury: an overview. Autonomic

Dysfunction after Spinal Cord Injury, v. 152 , p. 223-229, 2006.

LEE, K. H.; SUH-KIM, H.; CHOI, J. S.; JEUN, S. S.; KIM, E. J.; KIM, S. S.; YOON, D. H.; LEE, B. H. Human mesenchymal stem cell transplantation promotes functional recovery following acute spinal cord injury in rats. Acta Neurobiologiae Experimentalis, v. 67, n. 1, p. 13-22, 2007.

LIM, J. H.; BYEON, Y. E.; RYU, H. H.; JEONG, Y. H.; LEE, Y. W.; KIM, W. H.; KANG, K. S.; KWEON, O. K. Transplantation of canine umbilical cord blood-derived mesenchymal stem cells in experimentally induced spinal cord injured dogs. J ournal of Veterinary Science, v. 8, n. 3, p. 275282, 2007.

LIMA, C.; PRATAS-VITAL, J.; ESCADA, P.; HASSE-FERREIRA, A.; CAPUCHO, C.; PEDUZZI, J. D. Olfactory mucosa autografts in human spinal cord injury: A pilot clinical study. J ournal of Spinal Cord Medicine, v. 29, n. 3, p. 191-203, 2006.

LU, J.; ASHWELL, K. Olfactory ensheathing cells- Their potential use for repairing the injured spinal cord. Spine, v.27, n.8, p.887-892, 2002. 
LYALKA, V. F.; ORLOVSKY, G. N.; DELIAGINA, T. G. I mpairment of Postural Control in Rabbits With Extensive Spinal Lesions. J Neurophysiology, v. 101, n.4, p. 1932-1940, 2009.

MACKAY-SIM, A.; FERON, F.; COCHRANE, J.; BASSINGTHWAIGHTE, L.; BAYLISS, C.; DAVIES, W.; FRONEK, P.; GRAY, C.; KERR, G.; LICINA, P.; NOWITZKE, A.; PERRY, C.; SILBURN, P. A. S.; URQUHART, S.; GERAGHTY, T. Autologous olfactory ensheathing cell transplantation in human paraplegia: a 3-year clinical trial. Brain, v. 131, p. 2376-2386, 2008.

MARSHALL, G. P.; LAYWELL, E. D.; ZHENG, T.; STEI NDLER, D. A.; SCOTT, E. W. In vitro-derived "neural stem cells" function as neural progenitors without the capacity for self-renewal. Stem Cells, v. 24, n. 3, p. 731-738, 2006.

MEHTA, T.; FEROZ, A.; THAKKAR, U.; VANIKAR, A.; SHAH, V.; TRIVEDI, $\mathrm{H}$. Subarachnoid placement of stem cells in neurological disorders.

Transplantation Procedings, v. 40, n.4, p. 1145-1147, 2008.

NOSRAT, I. V.; WIDENFALK, J.; OLSON, L.; NOSRAT, C. A. Dental pulp cells produce neurotrophic factors, interact with trigeminal neurons in vitro, and rescue motoneurons after spinal cord injury). Developmental Biology, v. 239, n. 1, p. 176-176, 2001.

OGAWA, Y; SAWAMOTO, K; MIYATA, T.; MIYAO, S.; WATANABE, M.; NAKAMURA, M.; BREGMAN, B.S.; KOIKE, M.; UCHIYAMA, Y.; TOYAMA, Y.; OKANO, $\mathrm{H}$. . Transplantation of in vitro-expanded fetal neural progenitor cells results in neurogenesis and functional recovery after spinal cord contusion injury in adult rats. Journal Of Neuroscience Research, v.69, n. 6, p. 925-933, 2002.

OKADA, S.; NAKAMURA, M.; KATOH, H.; MIYAO, T.; SHIMAZAKI, T.; ISHII, K.; YAMANE, J.; YOSHIMURA, A.; IWAMOTO, Y.; TOYAMA, Y.; OKANO, H. Conditional ablation of Stat3 or Socs3 discloses a dual role for reactive astrocytes after spinal cord injury. Nature Medicine, v. 12, n. 7, p. $829-8342006$.

OLBY, N. J.; DE RISIO, L.; MUNANA, K. R.; WOSAR, M. A.; SKEEN, T. M.; SHARP, N. J. H.; KEENE, B. W. Development of a functional scoring 
system in dogs with acute spinal cord injuries. American J ournal of Veterinary Research, v. 62, n. 10, p. 1624-1628, 2001.

OLSON, L. Medicine: Clearing a path for nerve growth. Nature, v. 416, n. 6881, p. 589-590, 2002.

OTAKI, S.; UESHIMA S.; SHIRAISHI, K.; SUGIYAMA, K.; HAMADA, S.; YORIMOTO, M.; MATSUO, O. Mesenchymal progenitor cells in adult human dental pulp and their ability to form bone when transplanted into immunocompromised mice. Cell Biology International, v.31, n.10, p. 1191-1197, 2007.

OTHMAN, M.; KLUEBER, K.M.; ROISEN F.J. Identification and culture of olfactory neural progenitors from GFP mice. Biotechnic \& Histochemistry, v.78, n. 2, p. 57-70, 2003.

PADILHA FILHO, J. G.; SELMI, A. L. Discopatia cervical no cão. Tratamento cirúrgico através de fenestração ventral. Estudo retrospectivo (1986 - 1997). Ciência Rural, Santa Maria - RS, v.29, n.1, p. 75-78, 1999.

PAGANO, S. F.; IMPAGNATIELLO, F.; GIRELLI, M.; COVA, L.; GRIONI, E. ; ONOFRI, M.; CAVALLARO, M.; ETTERI, S.; VITELLO, F.; GIOMBINI, S.; SOLERO, C. L.; PARATI, E. A. I solation and characterization of neural stem cells from the adult human olfactory bulb. Stem Cells, n. 18, p. 295-300, 2000.

PARK, K. I.; HACK, M. A.; OUREDNIK, J.; YANDAVA, B.; FLAX, J. D.; STIEG, P. E.; GULLANS, S.; JENSEN, F. E.; SIDMAN R. L.; OUREDNIK. V., SNYDER, E. Y.; Acute injury directs the migration, proliferation, and differentiation of solid organ stem cells: evidence from the effect of hypoxia-ischemia in the CNS on clonal "reporter" neural stem cells. Experimental Neurology, v. 199, p.156-178, 2006.

PAUL, C.; SAMDANI, A. F.; BETZ, R. R.; FISCHER, I.; NEUHUBER, B. Grafting of human bone marrow stromal cells into spinal cord injury: a comparison of delivery methods. Spine, v. 15, n. 34, 328-334, 2009. 
RAMON Y CAJAL, S. Degeneration and Regeneration of the Nervous System (ed. May, R. M.) London: Oxford University Press, 1928.

RASOULI, A.; BHATIA, N.; DINH, P.; CAHILL, K.; SURYADEVARA, S.; GUPTA, R. Resection of glial scar following spinal cord injury. J ournal of Orthopaedic Research, v. 27, n. 7, p. 931-936, 2009.

RICHARDSON, P. M.; MCGUINNESS, U.M.; AGUAYO, A J. Axons from CNS neurons regenerate into PNS grafts. Nature, v. 284, 1980.

ROLLS, A.; SHECHTER, R.; LONDON, A.; SEGEV, Y.; JACOB-HIRSCH, J.; AMARIGLIO, N.; RECHAVI, G.; SCHWARTZ, M. Two faces of chondroitin sulfate proteoglycan in spinal cord repair: a role in microglia/macrophage activation. Plos Medicine, v. 5, n. 8, p. 1262-1277, 2008.

ROLLS, A.; SHECHTER, R.; SCHWARTZ, M. NEURON - GLIA INTERACTIONS - OPINION The bright side of the glial scar in CNS repair. Nature Reviews Neuroscience, v. 10, n. 3, p. 235-291, 2009.

RYU, H. H.; LIM, J. H.; BYEON, Y. E.; PARK, J. R.; SEO, M. S.; LEE, Y. W.; KIM, W. H.; KANG, K. S.; KWEON, O. K. Functional recovery and neural differentiation after transplantation of allogenic adipose-derived stem cells in a canine model of acute spinal cord injury. Journal of Veterinary Science, v. 10, n. 4, p. 273-284, 2009.

SCHWAB, M. E. Repairing the injured spinal cord. Science, v. 295, n. 5557, p. 1029-1031, 2002.

SEIM, H. B. Conditions of the toracolumbar spine. Seminars in Veterinary Medicine and Surgery (Small Animals), v. 4, pp 235-253, 1996.

SHARP, J.; KEIRSTEAD, H. S. Therapeutic applications of oligodendrocyte precursors derived from human embryonic stem cells. Current Opinion in Biotechnology, v. 18, n. 5, p. 434-440, 2007. 
SHIELDS, L. B. E.; ZHANG, Y. P.; BURKE, D. A.; GRAY, R.; SHIELDS, C. B. Benefit of chondroitinase $A B C$ on sensory axon regeneration in a laceration model of spinal cord injury in the rat. Surgical Neurology, v. 69, n. 6, p. 568-577, 2008.

SIEBERT, J. R.; STELZNER, D. J .; OSTERHOUT, D. J .; Chondroitinase treatment following spinal contusion injury increases migration of oligodendrocyte progenitor cells. Experimental Neurology, v. 231, n. 1, p. 19-29., 2011.

SOUZA, V. F.; LIMA, L. M. C.; REIS, S. R. A; RAMALHO, L. M. P.; SANTOS, J. N. Células-tronco: uma breve revisão. Revista de Ciências Médicas e Biológicas, v. 2, n. 2, p. 251-256, 2003.

SYKOVÁ, E.; HOMOLA, A.; MAZANEC, R.; LACHMANN, H.; , KONRÁDOVÁ S. L.; KOBYLKA, P.; PÁDR, R.; NEUWIRTH, J .; KOMRSKA, V.; VÁVRA, V.; STULÍK, J.; BOJAR, M. Autologous bone marrow transplantation in patients with subacute and chronic spinal cord injury. Cell Transplant, v.15, n. 8-9, p. 675-687, 2006.

TATOR, C. H.; FEHLINGS, M. G. Review of the secondary injury theory of acute spinal cord trauma with emphasis on vascular mechanisms. J ourna of Neurosurgery, v.75, p.15-26, 1991.

TOM, V. J .; HOULE, J. D. I ntraspinal microinjection of chondroitinase ABC following injury promotes axonal regeneration out of a peripheral nerve graft bridge. Experimental Neurology, v. 211, n. 1, p. 315-319, 2008.

TYMI ANSKI, M.; TATOR, C. H. Normal and abnormal calcium homeostasis in neurons: a basis for the pathophysiology of traumatic and ischemic central nervous system injury. Neurosurgery, v. 38, n.6, p. 1176-1195, 1996.

UEBLACKER, P.; WAGNER, B.; VOGT, S.; SALZMANN, G.; WEXEL, G.; KRUEGER, A.; PLANK, C.; BRILL, T.; SPECHT, K.; HENNIG, T.; SCHILLINGER, U.; IMHOFF, A. B.; MARTINEK, V.; GANSBACHER, B. In 
vivo analysis of retroviral gene transfer to chondrocytes within collagen scaffolds for the treatment of osteochondral defects. Biomaterials, v. 28, p. 4480-4487, 2007.

WEBB, A. A.; JEFFERY, N. D.; OLBY, N. J.; MUIR, G. D. Behavioural analysis of the efficacy of treatments for injuries to the spinal cord in animals. Veterinary Record, v. 155, n. 8, p. 225-230, 2004.

WEBB, A. A.; NGAN, S; FOWLER, JD. Spinal cord injury I: A synopsis of the basic science. Canadian Veterinary J ournal-Revue Veterinaire Canadienne, v. 51, n. 5, p. 485-492, 2010.

XU, X. M.; GUENARD, V.; KLEITMAN, N.; AEBISCHER, P.; BUNGE, M. B. A combination of BDNF and NT-3 promotes supraspinal axonal regeneration into Schwann cell grafts in adult rat thoracic spinal cord. Experimental Neurology, v. 134, p. 261-272, 1995.

XU, X. M., ZHANG, S. X., LI, H., AEBISCHER, P.; BUNGE, M. B. Regrowth of axons into the distal spinal cord through a Schwann-cell-seeded minichannel implanted into hemisected adult rat spinal cord. European J ournal of Neuroscience, v. 11, p. 1723-1740, 1999.

YANO, S.; KURODA, S.; LEE J. B.; SHICHINOHE, H.; SEKI, T.; IKEDA, J.; NISHIMURA, G.; HIDA, K.; TAMURA, M.; IWASAKI Y. In vivo fluorescence tracking of bone marrow stromal cells transplanted into a pneumatic injury model of rat spinal cord. Journal of Neurotrauma, v. 22, n. 8, p. 907-918, 2005.

YU, P.; HUANG, L.; ZOU, J.; ZHU, H.; WANG, X.; YU, Z.; XU, X. M.; LU, P.H. DNA vaccine against $\mathrm{NgR}$ promotes functional recovery after spinal cord injury in adult rats. Brain Research, v. 25, n. 1147, p. 66-76, 2007. 


\section{ANEXOS}

Anexo A - TERMO DE CONSENTIMENTO LIVRE E ESCLARECIDO

TERMO DE CONSENTI MENTO LI VRE E ESCLARECI DO

Projeto FAPESP - Fundação de Amparo a Pesquisa do Estado de São Paulo Processo no 2009/ 51605-04

“TERAPIA CELULAR COM CÉLULAS TRONCO EM COELHOS COM LESÃO MEDULAR EXPERI MENTAL E EM CÃES COM LESÃO MEDULAR CRÔNICA"

PESQUISADOR RESPONSÁVEL: Matheus Levi Tajra Feitosa

\section{I nformações I niciais}

O processo regenerativo de danos sofridos ao sistema nervoso central (SNC), e em especial a medula espinhal, apresenta alguns fatores limitantes, tais como a capacidade limitada do SNC em repor as células danificadas e a produção de inibidores de crescimento neuronal. Cães apresentam rotineiramente na clínica afecções da medula espinhal toracolombar, causada principalmente por herniação de discos intervertebrais. O canal medular toracolombar dos cães é bastante estreito, e a ocorrência de hérnia toracolombar pode levar a paralisia completa dos membros pélvicos com perda de sensibilidade e da função motora.

Animais com paralisia dos membros, mas que tenham ainda sensibilidade profunda preservada são candidatos à cirurgia descompressiva (descompressão ventral, hemilaminectomia e facetectomia lateral, laminectomia dorsal) ou a fenestração dos discos intervertebrais. Animais com perda da sensibilidade dolorosa profunda há mais de 48 horas, não são considerados candidatos à cirurgia devido à falta de expectativa de retorno à função locomotora. 
Há relatos consistentes de recuperação funcional em ratos com lesão medular tratados com células tronco mesenquimais (Mesenchymal stem cells - MSC). Estes tipos celulares "não neurais" apresentam um mecanismo diferente para a recuperação das lesões medulares onde não há a reposição de neurônios ou de células da glia. É bem provável que estes tipos de células forneçam suporte trófico, modulem a resposta inflamatória ou forneçam substratos para o crescimento de axônios, como eixos orientadores para a regeneração medular, promovendo a recuperação funcional.

Dentro desse contexto, a terapia celular com células-tronco surge como uma alternativa para os animais portadores de paralisia dos membros pélvicos posteriores. Como esse estudo se trata de um estudo experimental, obviamente não garantimos o sucesso do tratamento do seu animal, mas sim uma tentativa válida para a melhora da qualidade de vida do mesmo.

Nosso grupo de pesquisa possui ampla experiência com o uso das células-tronco em animais, e em particular, as células-tronco da polpa dentária humana imatura, que será utilizada neste experimento, já foram testadas quando a sua inocuidade pelo nosso grupo em cães do canil GRMD (Golden Retriever Muscular Dystrophy).

\section{Explicações do Estudo}

Você e seu animal estão sendo convidados para participar de um ensaio clínico que vai avaliar a eficácia das células-tronco na "lesão medular crônica", à doença do seu animal. Não há qualquer garantia que seu animal venha a ter um benefício direto com esse tratamento, muito embora, diversas tentativas clínicas tenham sido realizadas com resultados bastante promissores, em animais.

Uma vez aceitando participar desse estudo, seu animal será avaliado clinicamente, e serão realizados todos os exames necessários para que ele 
venha a correr o menor risco possível no momento da implantação das células-tronco. Após esses exames, se não houver alterações que impeçam a realização dos procedimentos cirúrgicos, seu animal será avaliado através de filmagens, que determinaram o sucesso do tratamento imposto. Essas filmagens terão de ser repetidas após 7 e 30 dias após o tratamento cirúrgico com as células-tronco, nesse quesito pedimos a sua colaboração em um esforço para determinar se seu animal reagiu ao tratamento, e ponderar sobre a possibilidade de reaplicação.

Seu animal será operado por um cirurgião com ampla experiência profissional em cirurgia de coluna de animais, e será acompanhado por pessoal competente e habilitado, tanto nos procedimentos anestésicos quanto na analgesia pós-operatória, no Hospital Veterinário Cães \& Gatos de Osasco-SP.

As células-tronco serão preparadas por pessoal altamente habilitado, em laboratórios de renome, em parceria com o Laboratório de Células Tronco (LCT) da Faculdade de Medicina Veterinária e Zootecnia (FMVZ) da Universidade de São Paulo (USP). Estas células já foram amplamente caracterizadas, e já foram realizados ensaios clínicos para avaliar sua inocuidade em ratos, coelhos e até mesmo em cães.

Seu animal será acompanhado continuamente, e qualquer alteração você poderá entrar em contato diretamente com os pesquisadores e profissionais envolvidos no projeto e será atendido(a) o mais breve possível. É importante frisar que esse é um procedimento inovador, e somente os profissionais envolvidos nessa pesquisa (cirurgião e pesquisadores) poderão Ihe atender de forma adequada e conveniente, com todas as explicações necessárias e pertinentes.

\section{Explicação sobre o Procedimento e Riscos}


Para que seu animal receba o transplante celular com células-tronco na medula espinhal, será necessária uma cirurgia descompressiva de medula, ou de estabilização da coluna vertebral. Essa cirurgia tem como finalidade retirar o fator que causou inicialmente a lesão medular ( $O$ disco herniado ou extrusado, ou interrupção de fluxo sanguíneo) e aplicar as células-tronco no foco da lesão medular. Para que essa cirurgia seja realizada, é necessária a realização da anestesia inalatória. Todo procedimento anestésico não é livre de risco, mas esses riscos estarão bastante reduzidos, pois contamos com profissionais habilitados para a realização de todos os procedimentos, e estaremos respaldados com exames pré-operatórios (hemograma, eletrocardiograma, dosagem de enzimas e exames de imagem) e a monitoração adequada do paciente ainda durante o procedimento (monitoração cardíaca, capnografia e oximetria de pulso).

Dentre as complicações possíveis decorrentes do procedimento, podemos citar infecção, formação de tecido não neuronal na medula espinhal, complicações anestésicas, arritmias e inclusive parada cardíaca súbita.

Animais com problemas cardíacos pré-existentes de difícil controle, ou de risco anestésico acentuado, serão descartados do projeto, com a finalidade de preservar a vida do animal em primeiro lugar.

\section{Benefícios que o seu Animal pode obter}

Embora não haja garantia de que você terá benefícios com este estudo, é possível que ocorra melhora parcial do estado de paralisia do seu animal, ou até mesmo uma recuperação funcional. Desde que estas células se diferenciem em tecido neuronal (e elas se diferenciam nesse tipo de tecido in vitro), seu animal pode vir a apresentar uma melhora clínica satisfatória, com melhoria da qualidade de vida do mesmo. 
Além do que, o acompanhamento clínico bem detalhado que seu animal receberá durante o período experimental pode servir de auxílio no tratamentodo mesmo, independente do benefício direto do estudo em si.

\section{Direitos do Proprietário e do Animal}

A sua participação é inteiramente voluntária. Durante o estudo você deve se sentir livre para questionar o que desejar, e caso não se considere suficientemente esclarerecido pelos profissionais que irão the atender, poderá solicitar o contato direto com o investigador responsável por este estudo, o Médico Veterinário Matheus Levi Tajra Feitosa, ou fazê-lo diretamente no telefone celular (011) 8050-6674.

Diante do exposto nos parágrafos anteriores, eu, firmado abaixo, (primeiro nome e sobrenome), residente à (endereço), concordo que o meu cão, do sexo ___-_, da raça ${ }_{---_{-}}$, de pelagem __-_-, participe do estudo "TERAPIA CELULAR COM CÉLULAS TRONCO EM COELHOS COM LESÃo MEDULAR INDUZIDA E EM CÃES COM LESÃO MEDULAR CRÔNI CA ESPONTÂNEA"

Eu fui completamente orientado pelo Médico Veterinário Matheus Levi Tajra Feitosa que está realizando o estudo, de acordo com a sua natureza, propósito e duração. Eu pude questioná-lo sobre todos os aspectos do estudo. Além disso, ele (a) me forneceu uma cópia essa folha de informações, a qual li compreendi e me deu plena liberdade para decidir quanto a participação do meu animal neste experimento.

Estou ciente que meu animal será filmado, e que porventura poderá ter sua imagem vinculada a revistas de cunho científico. Estou ciente que minha identidade será completamente preservada, e concordo que não irei restringir a divulgação dos resultados obtidos neste experimento.

Diante do exposto, concordo em cooperar com o Médico Veterinário Matheus Levi Tajra Feitosa, e com equipe composta pelo mesmo, e informar sobre qualquer alteração ocorrida em meu animal. 
Data e Assinatura procede que este tenha sido "Lido e Aprovado". Investigador: Data:

Assinatura:

Testemunha: Data:

Assinatura:

Testemunha: Data:

Assinatura:

Proprietário: Data:

Assinatura: 
Anexo B - Teste de avaliação comportamental

\section{Teste de Avaliação Comportamental}

Orientações:

1-Filmar todos os cães de ambos os lados e por trás ao caminhar em superfície não escorregadia (concreto como exemplo);

2-Cães que não conseguem suportar o próprio peso serão filmados tendo seu peso traseiro suportado pela base da cauda, permitindo dessa forma movimentos voluntários dos membros pélvicos;

3-A presença de sensação dolorosa profunda será avaliada pela pressão no leito ungueal dos dígitos (Se a presença de dor profunda for questionável cada dígito e a cauda serão testadas);

4- Consentimento dos clientes para a filmagem dos cães;

5- Os cães serão considerados como capazes de suportar o próprio peso quando eles suportarem o seu peso total com as articulações estendidas por pelo menos dois passos.

Sistema de Gradação (Olby et al., 2001)

0 - Ausência de movimento dos membros pélvicos sem sensação de dor profunda.

1 - Ausência de movimento dos membros pélvicos com sensação de dor profunda.

2 - Ausência de movimento dos membros pélvicos mas com movimentos voluntários da cauda.

3 - Mínima protração (movimento de uma articulação) do membro pélvico sem deslocamento de peso. 
4 - Protração dos membros pélvicos sem deslocamento de peso em uma articulação por pelo menos $50 \%$ do tempo.

5 - Protração dos membros pélvicos sem deslocamento de peso em uma articulação por mais de $50 \%$ do tempo.

6 - Protação dos membros pélvicos com deslocamento do peso em menos de $10 \%$ do tempo.

7 - Protação dos membros pélvicos com deslocamento do peso em 10 a $50 \%$ do peso do tempo.

8 - Protração dos membros pélvicos com deslocamento do peso em mais de $50 \%$ do tempo

9 - Protração dos membros pélvicos com deslocamento do peso em 100\% do tempo com força reduzida dos membros pélvicos. Mais de $90 \%$ de erro ao caminhar (por exemplo: Cruzando os membros pélvicos, andar arrastando os pés, permanecer em estação com os dorsos dos pés, tropeçar).

10 - Protração dos membros pélvicos com deslocamento do peso em $100 \%$ do tempo com força reduzida dos membros pélvicos. Erros em 50 a $100 \%$ do tempo.

11 - Protração dos membros pélvicos com deslocamento do peso em $100 \%$ do tempo com força reduzida dos membros pélvicos. Erros em menos de $50 \%$ do tempo.

12 - Marcha atáxica dos membros pélvicos com força normal, mas com erros em mais de $50 \%$ do tempo (por exemplo: falta de coordenação dos membros torácicos, cruzar os membros pélvicos, saltando etapas, salto de coelho, andar arrastando os pés na protração).

13 - Marcha atáxica dos membros pélvicos com força normal, erros em menos de $50 \%$ do tempo.

14 - Marcha dos membros pélvicos normal. 


\section{ANEXO C}

Deambulação de coelho 30 dias após hemissecção dorsal da medula espinhal (CD)

\section{ANEXO D}

Deambulação de coelho 30 dias após hemissecção ventral da medula espinhal (CD)

\section{ANEXO E}

Avaliação do reflexo de dor profunda em coelho após hemissecção ventral da medula espinhal $(C D)$

\section{ANEXO F}

Avaliação do reflexo de dor superficial em coelho após hemissecção ventral da medula espinhal (CD)

\section{ANEXO G}

Deambulação pré-operatória caso clínico 1 (CD)

\section{ANEXO H}

Deambulação caso clínico 1 quinze dias após transplante das células tronco da polpa dentária humana (CD)

\section{ANEXO I}

Deambulação caso clínico 1 trinta dias dias após transplante das células tronco da polpa dentária humana (CD)

\section{ANEXO J}

Deambulação caso clínico 1 sessenta dias transplante das células tronco da polpa dentária humana (CD)

\section{ANEXO K}

Deambulação pré-operatória caso clínico 2 (CD)

\section{ANEXO L}

Deambulação caso clínico 2 quinze dias após transplante das células tronco da polpa dentária humana (CD) 


\section{ANEXO M}

Deambulação caso clínico 2 trinta dias após transplante das células tronco da polpa dentária humana (CD)

\section{ANEXO N}

Deambulação caso clínico 2 sessenta dias após transplante das células tronco da polpa dentária humana (CD)

\section{ANEXO O}

Deambulação pré-operatória caso clínico 3 (CD)

\section{ANEXO P}

Deambulação caso clínico 3 quinze dias após transplante das células tronco da polpa dentária humana (CD)

\section{ANEXO Q}

Deambulação caso clínico 3 trinta dias após transplante das células tronco da polpa dentária humana (CD) 